\author{
UNIVERSIDADE DE SÃO PAULO \\ PROGRAMA DE PÓS-GRADUAÇÃO INTERUNIDADES \\ EM ENSINO DE CIÊNCIAS
}

Dóris Kohatsu

\title{
A interação luz-matéria integrando Física na Arte: uma proposta de ensino-aprendizagem para a Educação Básica
}





\section{UNIVERSIDADE DE SÃO PAULO \\ PROGRAMA DE PÓS-GRADUAÇÃO INTERUNIDADES \\ EM ENSINO DE CIÊNCIAS}

Dóris Kohatsu

\section{A interação luz-matéria integrando Física na Arte: uma proposta de ensino-aprendizagem para a Educação Básica}

\section{Versão corrigida}

(Versão original encontra-se na biblioteca do IFUSP)

Dissertação apresentada ao Programa de Pós-graduação em Ensino de Ciências da Universidade de São Paulo para obtenção do título de Mestre em Ensino de Ciências. Área de concentração: ensino de Física

Orientador: Prof. Dr. Mikiya Muramatsu 
Autorizo a reprodução e divulgação total ou parcial deste trabalho, por qualquer meio convencional ou eletrônico, para fins de estudo e pesquisa, desde que citada a fonte.

\section{FICHA CATALOGRÁFICA}

\section{Preparada pelo Serviço de Biblioteca e Informação} do Instituto de Física da Universidade de São Paulo

\section{Kohatsu, Dóris}

A interação luz-matéria integrando física na arte: uma proposta de ensinoaprendizagem para a educação básica. São Paulo, 2019.

Dissertação (Mestrado) - Universidade de São Paulo. Faculdade de Educação, Instituto de Física, Instituto de Química e Instituto de Biociências.

Orientador: Prof. Dr. Mikiya Muramatsu

Área de Concentração: Ensino de Física

Unitermos: 1. Física - Estudo e ensino; 2. Luz; 3. Cor; 4. Interdisciplinaridade; 5. Ensino de física; 6 . Arte.

USP/IF/SBI-072/2019 
Nome: KOHATSU, Dóris

Título: A interação luz-matéria integrando Física na Arte: uma proposta de ensino-aprendizagem para a Educação Básica

Dissertação apresentada ao Programa de Pós-graduação em Ensino de Ciências da Universidade de São Paulo para obtenção do título de Mestre em Ensino de Ciências.

Área de concentração: ensino de Física

Aprovada em 20.09.2019.

Banca Examinadora

Prof. Dr. Mikiya Muramatsu

Instituição: Instituto de Física - USP

Julgamento: Aprovada.

Prof. Dr. Thomaz Catunda

Instituição: Instituto de Física de São Carlos - USP

Julgamento: Aprovada.

Prof. Dr. Leonardo Crochnik

Instituição: Instituto Federal de São Paulo - campus São Paulo

Julgamento: Aprovada. 

A swami Chidvilasananda. 



\section{AGRADECIMENTOS}

Agradeço ao prof. Dr. Mikiya Muramatsu por desabrochar um potencial em mim que eu mesma desconhecia, pela sua forma amorosa de orientar e por me motivar: sua incansável crença em melhorar a realidade social pela Educação e pela Ciência me reanimava nos momentos sombrios que passamos recentemente na história desse país.

Agradeço a Rubens Zaccharias Jr e Jane Kohatsu por me ajudarem a desbravar um caminho novo para mim: a Arte.

Agradeço a meus pais Kossuke e Sachiko Kohatsu por uma educação cunhada em valores elevados. E meus irmãos, tios e tias que colaboraram na minha educação não formal.

Agradeço pelo apoio emocional e sábios conselhos a Armando Batalha de Gois, Fátima Ghazzouki, Cecil Chow Robillota, Luis Augusto Alves, Gabriel Sebton, Élcio Lopes, Diogo Soga, Michele Ueno Guimarães, Armando Tagiku, Lívia Nobre, Leila Kairalla, Levina M. Ferreira e à equipe de monitoras, monitores e colaboradoras do grupo Arte e Ciência no Parque, do Instituto de Física - USP.

Agradeço às professoras e professores que tornaram esta pesquisa possível: Carita, Amanda, Ana Maria, Andrea, Carol, Cíntia, Dani, Dé C, Dé P., Gis, Josi, Ju, Kátia, M. Elis, Quéli, Tamy, Van C., Van S., Denise, Gi, Izaque, Dayane, Deyvid, Sara, Yve.

Agradeço à Profa. Dra. M. Lúcia Habib e ao Prof. Dr. Ivã Gurgel pela orientação na banca de qualificação.

Agradeço a swami Chidvilasananda e swami Muktananda por me mostrarem o caminho da equilíbrio interior. 

"A arte não reproduz o visível, mas torna visível." Paul Klee ${ }^{1}$

\footnotetext{
${ }^{1}$ KLEE, Paul. Confissão criadora . Expresso Zahar. Edição do Kindle [posição 9], abril 2014.
} 



\section{RESUMO}

\section{A interação luz-matéria integrando Física na Arte: uma proposta de ensino- aprendizagem para a educação básica}

Em busca da dissolução de fronteiras disciplinares, elaboramos uma sequência de ensino aprendizagem integrando física e artes visuais de acordo com as habilidades e competências da Base Nacional Comum Curricular. Na dimensão da física, abordamos os conceitos físicos básicos sobre cor utilizando experimentos simples e tecnologias de informação e comunicação, possibilitando o desenvolvimento de habilidades epistêmicas. A dimensão artística abarca os aspectos de motivação e de comunicação pela observação de pinturas e por atividades criativas. A partir da perspectiva de desenvolvimento cognitivo históricocultural, fundamentamos a elaboração da sequência de ensino aprendizagem e a análise do desenvolvimento do pensamento conceitual. Investigamos a possibilidade de aprendizagem dos conhecimentos conceitual e epistêmico de Física na disciplina de Arte do ensino básico. Analisamos dados coletados com professoras de Arte da rede pública participantes de um curso de formação continuada. Concluímos que há um potencial da aprendizagem de termos básicos e atividades experimentais de física vinculados ao pensamento concreto.

Palavras-chave: luz, cor, interdisciplinaridade, ensino de ciências, arte . 



\section{ABSTRACT \\ The light-matter interaction integrating Physics in Art: a teaching-learning proposal for basic education.}

In pursuit of the dissolution of disciplinary boundaries, we have developed a teaching-learning sequence integrating physics and visual arts according to the skills and competencies of the Common National Curriculum (Base Nacional Comum Curricular - BNCC). In the Physics dimension, we approach the basic physical concepts of color using simple experiments and information and communication technologies, enabling the development of epistemic skills. The artistic dimension encompasses the aspects of motivation and communication through the observation of paintings and creative activities. From the perspective of historical-cultural cognitive development, we have based the elaboration of the teaching-learning sequence and the analysis of the development of conceptual thinking. We have investigated the possibility of learning the conceptual and epistemic knowledge of Physics in the Art course for K-12. We analyzed data collected with public art teachers participating in a continuing education course. We conclude that there is a potential for learning basic terms and experimental physics activities linked to concrete thinking.

Keyword: light, color, interdisciplinarity, science teaching, art. 

SUMÁRIO

1. INTRODUÇÃO 23

2. A COR NA PERSPECTIVA DA FÍSICA 27

2.1. Introdução histórica 17

2.2. A decomposição da luz 31

2.3. A interação luz-matéria 31

2.3.1. O que acontece quando um objeto é exposto à luz? 31

2.3.2.0 que determina se a luz será refletida, transmitida ou absorvida? 33

2.3.3. A reflexão da luz 34

2.4. A formação de cor nos objetos 38

2.5. Um modelo de visão de cor 41

2.6. As cores primárias 43

2.7. Mistura de cores 44

2.8. A percepção da cor 48

3. A PERSPECTIVA HISTÓRICO-CULTURAL 51

3.1. Uma visão geral do pensamento de Vigotski 51

3.2. A mediação e o desenvolvimento das funções cognitivas 53

3.2.1. A mediação cultural na Física 54

3.2.2. O mediador humano 54

3.3. A internalização do signo 55

3.4. Pensamento e linguagem 56

3.4.1. A formação do conceito 57

3.4.1.1. Sincretismo 58

3.4.1.2. Pensamento por complexo 59

3.4.1.3. Pensamento conceitual 61

3.4.2. A formação do conceito científico 63

3.5. Linguagem social, egocêntrica e interior 65

3.6. A linguagem escrita 66

3.7. Desenvolvimento e aprendizagem 67

3.8. Imaginação e criatividade 69

3.9. A formação integral - afeto e cognição 70

3.10. A prática de ensino-aprendizagem 71

3.10.1. Tempo de aprendizagem e estudo 72

3.10.2. Aprender é estudar 72

3.10.3. Definir o conceito no início de uma sequência de ensino- 72 aprendizagem

3.10.4. Experimentos científicos 73

3.10.5. Aprendizagem do conceito científico 74

3.10.6. Tecnologia da informação e comunicação (TIC) 74 
4. A SEQUÊNCIA DE ENSINO-APRENDIZAGEM 75

4.1. A construção da sequência de ensino-aprendizagem 75

4.1.1. A abordagem histórico-cultural $\quad 75$

4.1.2. As competências da Base Nacional Comum Curricular 76

4.2. Curso: Cor - Elo de Integração entre Arte e Ciência 78

4.3. Roteiro das atividades 83

5. METODOLOGIA DE PESQUISA 91

6. ANÁLISE DE DADOS 93

6.1. Visão geral 93

6.2. Avaliação pré e pós-curso 93

6.2.1.Teste geral 93

6.2.2. Imagens das pinturas da série da Catedral de Rouen por Monet 96

6.3. Doces coloridos - atividade experimental 101

6.4. Interação luz matéria - atividade artístico experimental 106

6.5. Luminosidade de superfícies coloridas - atividade 108 experimental

6.5.1. Identificação de variáveis $\quad 110$

6.5.2. Experimentação 111

6.6. Espectro da luz - atividade experimental 113

6.7. Disco rotativo: mistura aditiva de cores - atividade 117 experimental

6.8. Mistura subtrativa de cores - atividade artístico-experimental 119

6.9. Livros de Arte 123

7. CONCLUSÃO 131

8. CONSIDERAÇÕES FINAIS E PERSPECTIVAS FUTURAS 133

REFERÊNCIAS 135

APÊNDICE 1 - Orientação para produção do "livro de arte" 139

APÊNDICE 2 - Avaliação pré e pós-curso 141

ANEXO 1 - Resumos da oficina e da comunicação oral - Cor e 143 ciência no ensino de arte 


\section{MEMORIAL}

\section{Por que escolhi Física?}

Por volta dos cinco anos de idade, pela primeira vez fui acampar e pude ver o céu inundado de estrelas. Encantei-me... Decidi: vou estudar Astronomia. Criei o hábito de olhar o céu. Primeiro à procura das estrelas cadentes, depois pela sensação de expansão interior que me proporcionava mirar a imensidão.

Como sempre ia à praia, uma época quis estudar Oceanografia. Olhar o mar, estar no mar proporcionava-me enorme bem-estar. A natureza me atrai.

Quando estava na antiga oitava série, descobri que a palavra física etimologicamente significava natureza, as paixões se convergiram.

- Ah! Vou estudar Física.

\section{A graduação em Física}

Estudei a vida toda em escolas estaduais estando entre as melhores alunas apesar de não ser muito estudiosa. Quando prestei vestibular na FUVEST pela primeira vez, passei na primeira fase. Como não fizera cursinho e tivera um curso de segundo grau com deficiência, principalmente em Física, surpreendi-me com o resultado. Na prova escrita já foi diferente. Não consegui fazer quase nada. Após um ano de cursinho entrei no curso de bacharelado em Física.

O primeiro ano foi traumático. Tinha muita dificuldade de acompanhar o curso por falta de hábito de estudo e pelo alto nível de exigência das disciplinas. Antes eu não precisava estudar e ia bem. Agora era diferente. Nas primeiras provas tirei notas muito abaixo do que estava acostumada a tirar no ensino básico. O sentimento de êxtase pelo conhecimento também não veio estudando Física. Frustrei-me pela minha escolha. O sentimento de decepção era comum entre meus colegas. As amizades, a união na minha turma ajudou a me manter.

$\mathrm{Na}$ tentativa de dar certo na Física, fiz iniciação científica em Física Experimental, em Física Teórica, optativa de Astronomia, Oceanografia, Geofísica e nada... Até que cursei Estrutura e Funcionamento do Ensino, na Faculdade de Educação, com o professor João Pedro. Um novo mundo se revelou. Apaixonei-me por Educação! Transferi-me para a Licenciatura em Física e prestei vestibular para Pedagogia, na FUVEST e passei em primeiro lugar. No curso de Pedagogia, havia poucos desafios e uma postura meio arcaica da faculdade. Coincidiu com uma 
retomada aos estudos de música que abandonara na adolescência. Entrei no CoralUSP e na Escola Municipal de Música. Precisava escolher. Então, fiquei com Física e Música - Ciência e Arte.

\section{Idas e vindas}

Após me formar, estava empolgada. Tive sorte em conseguir aulas de Física numa escola estadual diferenciada na Vila Jaguara. Fora uma das escolas onde a proposta do GREF era aplicada, havia sala ambiente e a direção escolhida por eleição direta. Dava aula no curso noturno. Aparentemente tudo devia dar certo. Porém, não sentia envolvimento nem aproveitamento dos alunos. O clima na sala dos professores era depressivo. A vida real era diferente da idealizada. Decepcioneime e no final do primeiro bimestre deixei a escola. No segundo semestre consegui aulas de Física e Química, perto de casa, numa escola estadual conhecida. Tentei novamente. Nova decepção.

Pensei em estudar a natureza de uma forma mais prática. Permaneci um semestre na ESALQ como aluna de Engenharia Agronômica. Fui morar num sítio, trabalhei numa loja de departamentos, lia muito. Até que comecei a meditar, praticar yoga e estudar filosofias clássicas da Índia. Encontrei o que buscava. E voltei para a Física. Comecei a trabalhar numa escola particular no Butantã com um grupo de professores engajados em Educação, a maioria era da USP.

Fiquei três anos nessa escola. Interrompi para ir morar um ano para aprofundar os estudos em yoga na Índia. Voltei e retomei em outra escola particular. Passei vinte e três anos dando aulas de Física na rede privada, dezoito numa mesma escola. Nem tudo eram flores, pensei em mudar de profissão numa época muito desgastante e que ganhava mal, mas não sabia o que fazer porque gostava de dar aulas de física. $O$ amadurecimento trouxe segurança e estabilidade. Até que em 2015 prestei o concurso para professora de Física no Instituto Federal de São Paulo apenas para me avaliar. Fui aprovada em quarto lugar. Hmmm... bom resultado. Pelo edital havia apenas uma vaga, daria tempo de me aposentar pelo INSS até me chamarem. Em 09 de janeiro recebi um email de convocação, deveria me apresentar com uma lista enorme de documentos e exames médicos no dia 11 às 15:00. Nomearam quatro professores! Comecei uma nova fase da vida. 


\section{A pós-graduação}

Há alguns anos participei de cursos de formação continuada na Estação Ciência e no IFUSP. Junto com outros professores fui convidada pelo professor Mikiya para integrar a equipe de um projeto de ensino de Óptica a fim de avaliar um kit didático. Depois desse projeto, participei de outros de formação de professores da rede estadual. Durante oito anos aprendi muito. Quis ingressar na pós-graduação naquela época mas trabalhava em duas escolas e não havia condições. No Instituto Federal, a realização do mestrado se tornou possível. O retorno à universidade vem me revelando uma área nova de ensino de Física. Percebi que aprendi na graduação e durante a longa vida docente era muito pouco. Na verdade, quanto mais estudo, parece que há mais ainda para saber - o aprender é infindável. O percurso no mestrado tem me ajudado a refletir sobre meu desenvolvimento profissional de professora. Acho o tempo de mestrado pequeno. Reconheço mais ainda, que a formação tanto em física como em pedagogia e psicologia na graduação é insuficiente. O desaprender e o reaprender são mais significativos quando permeados pelos anos de experiência em sala de aula.

A escolha de Vigotski como referencial esclareceu muitas questões de sala de aula, como a influência das dimensões afetiva-volitiva, do aprendizado no desenvolvimento humano, o papel da professora na mediação do aprendizado, a realização de experimentos, a resolução de problemas. Tudo que inclui no resumo sobre a perspectiva vigostkiniana foi uma forma de aprender para poder aplicar em sala de aula.

A escolha da cor como tema trouxe-me a noção da complexidade de estudar de um assunto multidisciplinar. Percebi a necessidade do recorte para a pesquisa mas sai inquieta.

$\mathrm{Na}$ entrevista de seleção para o mestrado, a banca me perguntou se eu tinha alguma questão. Respondi que não. Na entrada da pós, tive dificuldade em encontrar questões. Agora na saída, a dificuldade está em responder todas as questões. Talvez este seja o papel de um programa de pós-graduação, desenvolver o pensamento crítico, abrindo a visão para aquilo que necessita de respostas. 



\section{INTRODUÇÃO}

A cor preta se tornou protagonista no mundo artístico nos últimos anos. Em 2014, Anish Kapoor, artista visual indiano radicado na Inglaterra, adquiriu exclusividade de uso do "preto mais preto", o Vantablack², uma substância elaborada por nanotubos de carbonos que absorve em média 99,96\% da luz. Como resposta a isto, o artista pesquisador inglês Stuart Semple desenvolveu as tintas pretas Black 2.0 e, neste ano, a Black 3.0 (99\% de absorbância média da luz) disponível para todos, exceto para Anish Kapoor. O Singularity Black ${ }^{3}$ (99\% de absorbância média da luz) desenvolvido originalmente em 2011 para uso de equipamentos de observação pela NASA, foi utilizado para criação artística em 2017 por Jason Chase, artista norte-americano (Cascone 2017, 2019) ${ }^{4}$.

Esta história ilustra como a ciência e a tecnologia afetam a arte. Em geral, nos planos educacionais, argumenta-se sobre a necessidade da aprendizagem de física para se compreender as tecnologias, formar-se um cidadão capaz de opinar conscientemente sobre questões científicas, ambientais, tecnológicas. Costumamos associar a tecnologia com máquinas, dispositivos eletrônicos e afins. No entanto, arte e ciência usam as mesmas ferramentas e materiais; a tecnologia torna-se o seu principal elo. Mudanças dramáticas nas artes visuais são impulsionadas por novas descobertas científicas e novas tecnologias (Strosberg 2015). Nas técnicas de pintura, por exemplo, a síntese de pigmentos, a invenção de tubos de tinta óleo e a invenção do cavalete permitiram a pintura ao ar livre dos impressionistas. Não só a ciência influenciou a arte, cientistas como Helmhotz, Brücke e Chevreul que estudaram a óptica fisiológica e psicológica foram influenciados pelas obras dos pintores impressionistas (Schapiro 2002).

$\mathrm{Na}$ história da cultura humana os saberes aparentemente opostos como Arte e Ciência dialogam. A cultura escolar fragmenta o conhecimento formando um cidadão com visão segmentada da realidade que o cerca. Na educação, a aproximação das duas culturas, ciências exatas e ciências humanas/arte, possibilita

\footnotetext{
2 Desenvolvido pela empresa birtânica Surrey NanoSystems, o Vantablack não é uma tinta preta, pigmento ou tecido, mas é uma "floresta" funcional de nanotubos de carbono com um diâmetro de cerca de $20 \mathrm{~nm}$ e entre 14 microns a 50 microns de comprimento. $1 \mathrm{~cm}^{2}$ conteria cerca de 1.000 milhões de nanotubos. Disponível em https://www.surreynanosystems.com/vantablack/faqs [acesso em 10.07.2019].

${ }^{3}$ Disponível em https://www.nano-lab.com/optical-black-coatings.html [acesso em 10.07.2019].

${ }^{4}$ Sarah Cascone, August 4, 2017. Artnet. Disponível em https://news.artnet.com/art-world/singularityblack-blackest-paint-1042202 [acesso em 10.07.2019].
} 
a formação de técnicos/cientistas com visão mais humanista e profissionais das ciências humanas e artistas como melhor formação científica (Snow 1959). A ciência, trabalhando em prol de objetivos coletivamente reconhecidos e precisos, tenta remover ambiguidades que a arte aceita e até enfatiza como inevitáveis no campo da experiência subjetiva. Artistas e cientistas têm pontos convergentes como dar nascimento a ideias e formas - a criatividade; o uso da imagem e a imaginação; a beleza e a disciplina (Strosberg 2015, p. 11-13).

No limiar do século XXI, a comissão da Unesco sinaliza a necessidade de um sistema educacional mais flexível, com maior possibilidade de transferência entre diversas modalidades de ensino (Delors et alli, 1996). A Base Nacional Comum Curricular (BNCC) propõe uma educação integral visando a formação e o desenvolvimento global do ser humano contra a fragmentação do conhecimento, buscando romper as barreiras entre as dimensões racionais e afetivas. Espera-se assim, a formação de um cidadão capaz de se comunicar, ser criativo, analíticocrítico, participativo, aberto ao novo, colaborativo, resiliente, produtivo e responsável (Brasil 2017).

Os artistas visuais parecem indicar um caminho para integração destas dimensões ao se apropriarem do conhecimento científico e empregá-lo em suas criações artísticas. A cor é tema de estudo das artes, das ciências da natureza, da filosofia, da psicologia. Há o apelo estético, de encantamento e relaciona-se com muitos fenômenos cotidianos. Na física, o estudo da cor insere-se dentro do contexto da interação luz-matéria.

Em geral, os esforços das pesquisas em ensino de Ciências direcionam seu olhar em aplicar a arte no ensino de física. Sobre o tema cor destacamos, no Brasil, o uso das pinturas de Monet para contextualizar o ensino de óptica na disciplina de Ciências no $9^{\circ}$ ano do ensino fundamental (Brito e Reis 2014, 2015). A arte proporcionou o conhecimento de patrimônio cultural, a observação de imagem e criação artística. Internacionalmente, uma proposta interdisciplinar de cor e matemática (teoria dos conjuntos) utiliza um aplicativo de cores (Karabey et al 2018) $)^{5}$. O projeto Colors of Nature ${ }^{6}$ (Conner et al. 2019) integra arte e ciências

\footnotetext{
${ }^{5}$ KARABEY, B. et al. Discovering complementary colors from the perspective of steam education. Physics Education, Volume 53, Number 3. Diponível em http://iopscience.iop.org/article/10.1088/13616552/aa97bf/meta [acesso em 19.07.2019]
} 
(física, química e biologia) em atividades escolares para o ensino fundamental. Os quatro módulos disponíveis online fornecem conteúdo e metodologia fundamentada no ensino investigativo. O projeto também realiza atividades de divulgação científica. O Eurekus ${ }^{7}$ (Aiello et al. 2019) em parceria com a NASA desenvolve propostas (STEAM - Science, Technology, Engineering, Art and Mathematics) de arte no ensino de ciências, astronomia, geologia e ciências espaciais direcionadas para crianças e ensino fundamental. Há amplo material online.

A didática das ciências para o século XXI necessita redirecionar seus esforços a fim de compreender melhor como o compromisso emocional e intelectual se combina com o encanto pelos fenômenos naturais nas crianças e nos jovens; como apresentar as formas científicas de conhecer relacionadas construtivamente com outras formas humanas de conhecer (Lemke 2006). O esforço em aproximar Arte e Ciência nos inspirou à questão de pesquisa:

Quais as possibilidades da aprendizagem de física da Cor na disciplina de Artes?

O objetivo geral consiste em avaliar o potencial de uma sequência de ensino aprendizagem de conhecimentos físicos sobre cor visando a aplicação na disciplina de Arte do ensino fundamental, integrando práticas de Física e de Artes Visuais.

Os objetivos específicos são:

i. determinar os conceitos relevantes sobre cor visando uma formação básica no ensino fundamental a partir da literatura científica e da Base Nacional Comum Curricular do Ensino Fundamental;

ii. pesquisar, selecionar, testar e adequar atividades experimentais e artísticas para serem desenvolvidas coletivamente ou individualmente;

iii. pesquisar, selecionar e testar aplicativos disponíveis para Android e/ou Windows;

iv. pesquisar, selecionar vídeos e trechos desses vídeos para servirem como instrumento para compreensão do conceito físico e ilustração do uso da linguagem artística na comunicação de conceitos científicos;

\footnotetext{
${ }^{6}$ Projeto desenvolvido pelas University of Alaska Fairbanks, National Optical Astronomy Observatory (Tucson, Arizona) e University of Washington Bothell . Disponível em http://www.colorsofnature.org/ [acesso em 19.07.2019]

'Disponível em http://www.eurekus.org/nasa-program-teaching-resources [acesso em 10.07.2019]
} 
v. pesquisar e selecionar imagens de pinturas de artistas a fim de ilustrar a apropriação de conceitos sobre cor na criação de obras artísticas. 


\section{A COR NA PERSPECTIVA DA FÍSICA}

\subsection{Introdução histórica}

Desde a Antiguidade a questão de por que os objetos possuem cor ou como se formam as cores intriga filósofos e cientistas. Para Aristóteles de Estagira (384322 a.C.) a luz do Sol pura, transparente e incolor ao interagir com um objeto escurecia pois degradava no processo de formação da cor. A cor viajava do objeto para os olhos do observador. No De sensu et sensibili, Aristóteles considera uma escala linear de sete cores - branco, amarelo, vermelho, violeta, verde, azul e preto uma gradação do claro ao escuro, provendo uma escala de cores utilizada pelos artistas nos séculos seguintes. No livro III de Meteorologica, Aristóteles discute o arco-íris e identifica as três cores primárias aditivas, vermelho, verde e azul, diferenciando-as das cores primárias subtrativas dos pintores. Por volta do ano 1000, por influência da ciência arábica, as três cores primárias do arco-íris passam a ser quatro, vermelho, verde, azul e amarelo, correspondendo aos quatro elementos fogo, água, ar e terra, respectivamente (Parkhust 1982, p.226).

No século XVII , havia maior entendimento das propriedades ópticas da luz mas a origem da cor continuava desconhecida. Sob a influência aristotélica, a luz sob sua forma mais pura, a luz do Sol, era considerada transparente. A maior parte das teorias atribuía cor do objeto a algum tipo de modificação que acontecia quando a luz interagia com a matéria, mas não explicavam que mudança acontecia com a luz (Overheim 1982).

A decomposição da luz no arco íris e no problema da aberração cromática em lentes de telescópios e microscópios eram fenômenos conhecidos. Descartes (1637), Grimaldi (1637), Boyle (1664) e Hooke (1665) realizaram o experimento com o prisma mas observaram somente uma mancha de luz branca, colorida nas extremidades (Rival 1997, p. 27) (Rocha 2002, p. 219). O experimento da decomposição da luz necessita poucos recursos - um prisma e luz do sol - mas requer execução minuciosa. Para ter sucesso, Newton foi muito cuidadoso. Numa sala totalmente escura, Newton fez um orifício da ordem de um centímetro numa tábua da janela por onde entrava um feixe de luz solar que incidia sobre um prisma de vidro. Na parede oposta a 5,5 m do prisma, observou uma faixa oblonga colorida, efeito da luz solar refratada pelo prisma (Newton 1996, p.56). Em experimentos subsequentes, utilizando dois prismas, realizou a recomposição das luzes coloridas 
formando novamente a luz branca. Concluiu que a luz branca é uma mistura de luzes de todas as cores. Inicialmente, Newton identificou cinco cores no espectro da luz solar branca - violeta, azul, verde amarelado, amarelo e vermelho. O espectro de sete cores - violeta, anil, azul, verde, amarelo, alaranjado e vermelho - surgiu da analogia com as sete notas da escala musical (Newton 1996, p.116). Newton publicou sua teoria das cores em 1672, no Philosophical Transctions e posteriormente, em 1704, no livro Óptica, (Assis, in Newton 1996, p.18) onde detalhadamente descreve os experimentos que realizou com prismas e lentes. Os pontos principais da teoria de cores newtoniana são:

i. a luz solar branca é composta por sete cores;

ii. a existência do raio de luz colorido, que chamou de luz homogênea, independente da interação com o meio material, negando a concepção aristotélica da cor como degradação da luz solar após a interação com um meio material;

iii. a existência independente de cada raio de luz colorido (luz homogênea) com índice de refração característico. A cor da luz homogênea não pode ser modificada nem por reflexões, nem por refrações (Newton 1996, p.113);

iv. as cores do universo são produzidas pela interação da luz com o objeto luz (Newton 1996, p.134);

v. uma mesma cor pode existir como luz homogênea, prismática e como a mistura de outras luzes homogêneas. Por exemplo, a luz laranja resultado dispersão da luz solar, pode ser composta misturando luz vermelha e luz amarela (Newton 1996, p.120). Descreve aqui o fenômeno do metamerismo um mesmo efeito visual de uma cor gerado de formas distintas (Williamson e Cummins 1983, p.80).

Newton também descreve a variação na sensibilidade da percepção das cores. Observa que amarelo e laranja são mais luminosas, seguidas pelo vermelho e o verde. Azul anil e violeta são cores mais fracas e escuras (Newton 1996, p.99). Hoje sabemos que o olho humano tem maior sensibilidade comprimento de onda médio (amarelo e verde) e menor para comprimentos de onda curto (azul, anil e violeta) (Livingstone 2014, p.33).

Wolfgang Goethe, considerado o maior poeta alemão, publica em 1810 a sua Doutrina das Cores em contraposição a teoria newtoniana das cores. Divide o fenômeno da cor em cores fisiológicas, cores física e cores químicas conforme a 
duração da manifestação da cor. A cor fisiológica acontece no olho e é a de maior permanência. "As cores fisiológicas são o fundamento de toda a doutrina e nos revelam a harmonia cromática, que deu origem a tantos conflitos" (Goethe 2018, local $845^{8}$ ).

A cor física é efêmera, difícil de fixar e produzida fora do olho, pela passagem da luz em meios incolores, transparentes ou pela reflexão da luz em meios opacos. A cor química é mais duradoura, são cores nos corpos. A cor também produz efeitos morais e emocionais sobre o indivíduo (Goethe 2018).

A crítica de Goethe a Newton evidencia um confronto de dois modos completamente distintos de pensar a natureza. A física newtoniana estuda objetivamente o fenômeno cromático. O idealismo alemão recusa a ótica mecanicista, já que interpreta tanto a natureza quanto a arte a partir da ideia de organismo, de uma finalidade interna (Gianotti 1993, in Goethe 2018, local 348).

Apesar de Goethe defender a interpretação das cores pela visão humana, foram as ideias de Descartes, Newton e outros sobre as vibrações que a luz causa na retina que influenciaram Young na elaboração da teoria tricromática da visão de cores. Em 1802, Thomas Young propôs inicialmente a existência de três receptores na retina, vermelho, amarelo e violeta; mudando poteriormente para vermelho, verde e violeta. Um ou dois receptores são estimulados pela luz determinando uma cor. Se a luz estimular os três receptores igualmente, a cor percebida é branca (Heesen 2015). Young argumentou que não podemos ter um grande número de diferentes detectores de comprimentos de ondas porque se assim o fosse, precisaríamos um receptor específico para cada ponto da retina (Livingstone 2014, p.40).

Em 1855, James C. Maxwell realizou um experimento misturando três luzes homogêneas - vermelho, verde esmeralda e azul ultramarino - quantificando a proporção nas misturas para obter as outras cores. Mostrou que todas as cores podem ser decompostas em três cores básicas. Maxwell acreditava que há uma infinidade de luzes homogêneas, então a decomposição em três cores básicas era um fato do olho humano e não da luz física (Heesen 2015). Entre 1860 e 1865 Maxwell determinou as intensidades das luzes vermelho, verde e azul em uma

\footnotetext{
${ }^{8}$ Edição Kindle.
} 
mistura de cada cor do espectro, sugerindo o princípio da fotografia colorida (Jones 1953, p.38).

Maxwell faz uma mudança radical na teoria de Young propondo que a luz de qualquer cor afeta os três modos de sensação, em diferentes intensidades. Ele pontua, no entanto, que é difícil investigar as sensações puras das cores. Baseandose na teoria de Maxwell e Young, Helmhotz realiza experimentos medindo as intensidades relativas das cores complementares para produzirem o branco, esboçando uma curva que representa como a luz se mistura no olho (Heesen 2015).

Hermann von Helmhotz (1821-1874), matemático, médico e físico alemão é responsável pela demonstração das diferenças nas misturas de cores provenientes de luz e de cores provenientes de pigmentos o que originou a terminologia: mistura aditiva e mistura subtrativa (Feitosa 2006).

A cor luz como parte do espectro visível da luz só se efetivou no século XIX após a teoria eletromagnética de Maxwell ser comprovada experimentalmente por Hertz em 1888. A luz é uma onda eletromagnética, onde cada cor possui determinada frequência ou comprimento de onda ${ }^{9}$ eletromagnética (figura 1) (Overheim 1982).

Figura 1 - Espectro eletromagnético.

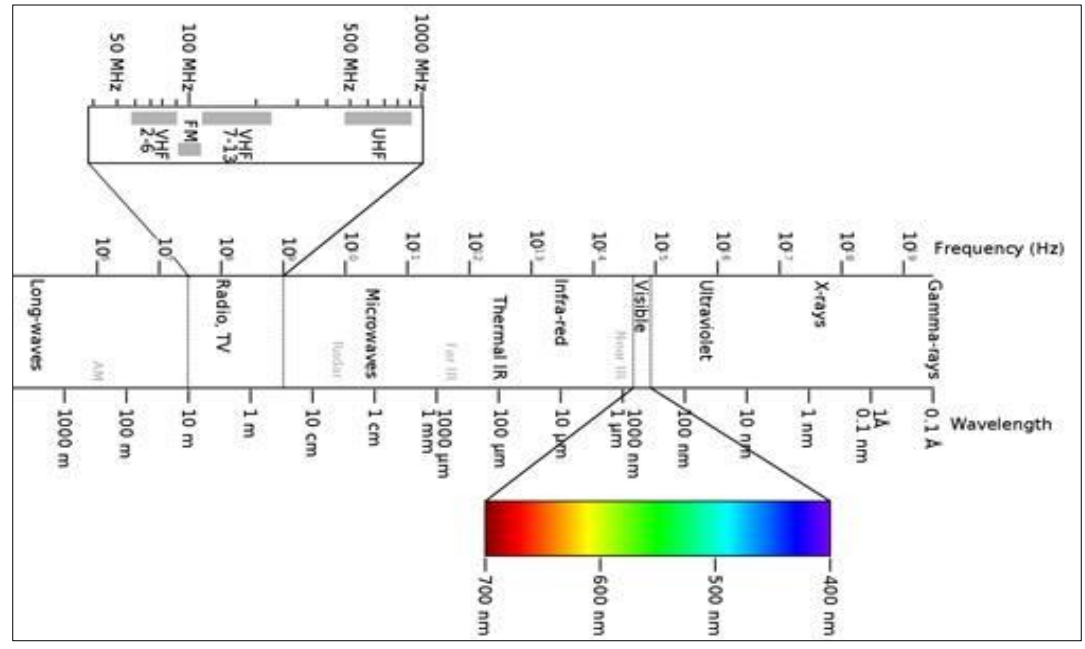

By Original:PenubagVector:Victor Blacus - Own work based on: Electromagnetic-Spectrum.png, CC BY-SA 3.0. Disponível em: https://commons. wikimedia.org/w/index.php?curid=22428451 [acesso em 25.07.2018].

\footnotetext{
${ }^{9}$ A cor relativa a cada comprimento de onda, em nm, e sua codificação no sistema RGB e hexadecimal pode ser visualizada no aplicativo disponível em [acesso em 06.02.2019] https://academo.org/demos/wavelength-to-colour-relationship/
} 


\subsection{A decomposição da luz}

A luz solar ou a luz branca de uma lâmpada é uma luz policromática. O espectro da luz pode ser observado através da decomposição do feixe luminoso por refração ou por difração, fenômenos que dependem do comprimento de onda da luz.

A decomposição da luz por refração ${ }^{10}$ ocorre quando a luz muda o meio de propagação. Num prisma de acrílico, a luz caminha do ar para o acrílico e do acrílico para 0 ar. Cada cor que compõem a luz branca emerge do prisma com um ângulo diferente podendo formar o espectro visível da luz num anteparo.

Quando a onda luminosa passa por um orifício muito pequeno como os presentes num $C D$, ocorre o fenômeno da difração. A onda luminosa é parcialmente desviada num ângulo que depende do comprimento de onda, separando a luz branca em suas componentes. Os milhares de orifícios que constituem o CD reforçam o efeito da difração, permitindo a visão do espectro da luz incidente.

\subsection{A interação luz-matéria}

Conceitos físicos relativos a cor podem ser explicados a partir do modelo clássico da luz como onda eletromagnética e pelo modelo tricromático de visão de cores. Dentro de um sistema conceitual, a formação da cor nos objetos subordina-se ao estudo da interação de luz-matéria.

\subsubsection{O que acontece quando um objeto é exposto à luz?}

A luz como onda eletromagnética é uma forma de energia radiante. Após interagir com o objeto material, a luz transporta informações sobre aparência do objeto - opacidade/transparência, cor e forma. Pelo princípio de conservação de energia, a energia é transformada em outras formas de energia. Em circunstâncias especiais, a massa pode ser convertida em energia, e energia em massa, processos que não estudaremos. Nos processos de interação luz-matéria, a luz incidente (energia inicial) pode ser refletida, transmitida ou absorvida (Nassau 1983, p. 26).

\footnotetext{
${ }^{10}$ A construção de um prisma caseiro encontra-se em SOGA, D., KOHATSU, D., MURAMATSU, M. Revisitando os prismas caseiros. Física na Escola, v.16, $\mathrm{n}$ 2, 2019. Disponível em : http://www1.fisica.org.br/fne/phocadownload/Vol16-Num2/a14-low.pdf [acesso em 08.10.2019].
} 


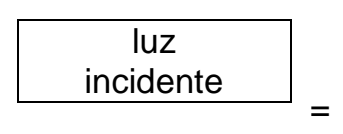

energia inicial

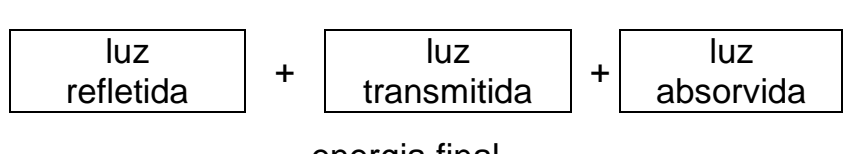

energia final

A aparência do objeto é determinada pela percepção do indivíduo da quantidade de cada parcela da energia luminosa final captada pelo sistema visual. Um objeto opaco possui baixa transmissividade e maior refletância da luz. Quanto maior a transparência maior a parcela de luz transmitida. A cor do objeto depende das frequências da radiação absorvida. A energia da radiação absorvida aumenta a energia cinética média das partículas constituintes do material se transformando em calor. A figura 2 ilustra fenômenos ópticos decorrentes da incidência da luz sobre um meio Figura 2 - O esquema representa os possíveis fenômenos consequência da incidência da luz sobre um objeto sólido.

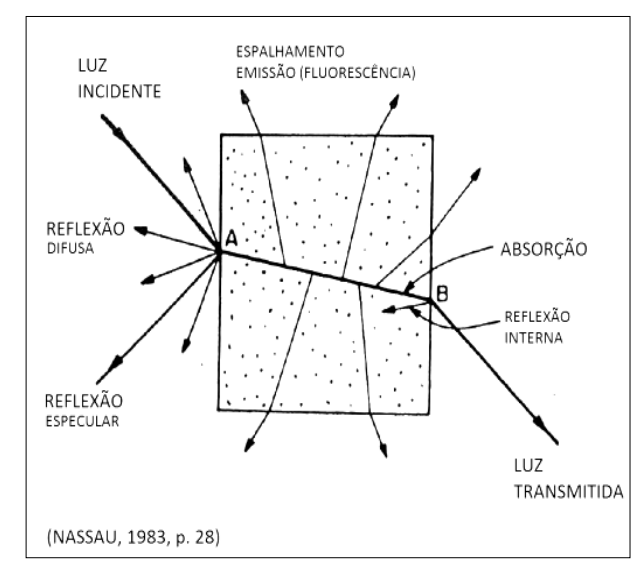
material.

A energia luminosa final depende da energia incidente. Um mesmo objeto pode parecer ter coloração distinta conforme a luz incidente. O pintor francês Claude Monet (1840-1926) estudava os efeitos luminosos pintando um mesmo local em diferentes horários, estações do ano, condições climáticas e anos distintos. A série da catedral de Rouen contém trinta telas onde Monet registrou o efeito da luz sobre a fachada da catedral em diferentes condições atmosféricas entre 1892 e 1894 . Na figura 3 mostramos a seleção de nove pinturas (Martins e Imbrosi $)^{11}$.

\footnotetext{
11 MARTINS, Simone R.; IMBROISI, Margaret H. Impressionismo. [Acesso em 21 março 2018] Disponível em: http://www.historiadasartes.com/nomundo/arte-seculo-19/impressionismo/.
} 
Figura 3 - Catedral de Rouen (1892-1894). Seleção de nove telas da série de pinturas de Monet que registram o efeito da variação da luz sobre um mesmo objeto. A numeração refere-se ao catálogo Wildenstein.

\begin{tabular}{|lllll|}
\hline & & & & \\
\end{tabular}

Disponível em https://commons.wikimedia.org/wiki/Monet -

Les Cath\%C3\%A9drales de Rouen [acesso em 25.10.2018].

\subsubsection{O que determina se a luz será refletida, transmitida ou absorvida?}

$\mathrm{Na}$ física clássica, considera-se a matéria é constituída pelo átomo clássico os elétrons orbitando em torno do núcleo positivo. Na matéria densa, os átomos estão ligados entre si formando uma rede de dipolos elétricos.

A onda eletromagnética é composta de um campo magnético e um campo elétrico. Nas interações da luz com a matéria, o campo magnético não sofre alterações, por isso nos interessa somente a influência do campo elétrico. A luz de uma fonte $S$ com campo elétrico $E_{i}$ e frequência $\omega$ incide sobre um objeto (figura 4 ) . Os elétrons do objeto, que oscilam com uma frequência natural de oscilação $\omega_{0}$, sob 
a ação da força gerada pelo campo elétrico $E_{i}$ comportam-se como um oscilador harmônico. A onda incidente gera uma oscilação forçada no elétron. Se a frequência da onda incidente (frequência forçada) for aproximadamente igual à frequência natural do elétron $\left(\omega_{0} \approx \omega\right)$, o elétron entra em ressonância e a onda é absorvida. Os elétrons não ressonantes podem irradiar uma nova onda. Os elétrons da camada de espessura ( $\lambda / 2)$ próxima à superfície do objeto podem reemitir na direção simétrica à onda incidente (para "trás"), em interferência construtiva, gerando a onda refletida, de campo elétrico $E_{r}$. As ondas reemitidas na direção da onda incidente, em interferência construtiva, geram uma onda transmitida cujo campo elétrico resulta do campo elétrico da fonte e da soma dos campos gerados por cada carga $\mathrm{E}_{0}$. (Feyman 2008, p.31-1, v.2) (Weiskopff 1968, pp.63-7). ${ }^{12}$

Figura 4- O campo elétrico da onda luminosa interage com a matéria, podendo ser refletida ou transmitida.

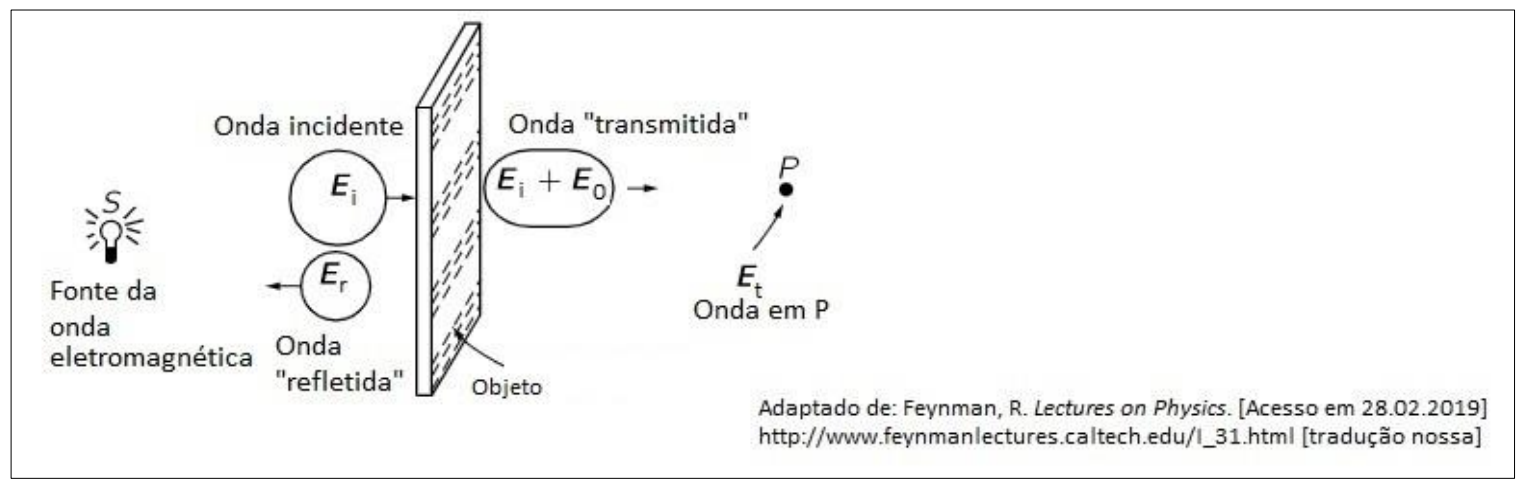

\subsubsection{A reflexão da luz}

A amplitude de uma reflexão por superfície não é uma propriedade do material, como é o caso do índice de refração. É uma "propriedade de superfície" que depende precisamente de como a superfície formou-se (Feymann 2008, p. 33-1, v.2, aspas do autor). Numa superfície de matéria densa, segue-se a lei da reflexão o ângulo de incidência é igual ao ângulo de reflexão. Pode ocorrer reflexão especular ou difusa da luz conforme a rugosidade da superfície.

A reflexão especular da luz surge quando um feixe de luz incide numa superfície lisa ou especular. O feixe de luz reflete paralelamente numa única

\footnotetext{
${ }^{12}$ Considera-se que "o campo elétrico total em qualquer circunstância física pode ser sempre representado pela soma dos campos de todas as cargas do Universo (...) ; a contribuição de cada carga não é modificada pela presença de outras cargas" (Feynman 2008, p.31-1, v.2).
} 
direção. A luz não penetra muito no meio interagindo pouco com os pigmentos. A cor da luz refletida é igual a da luz incidente (figura 5).

Numa superfície rugosa há a difusão da luz ou reflexão difusa da luz. A luz penetra o meio e é afetada pelas irregularidades da estrutura, sendo refletida pelas partículas do pigmento, emergindo em todas as direções. A reflexão difusa da luz é fortemente influenciada pela absorção seletiva da superfície (Williamson e Cummins1983, p.41). Há maior interação da luz com a superfície do objeto, permitindo a visualização do objeto - forma e cor (figura $6 a$ a, b).

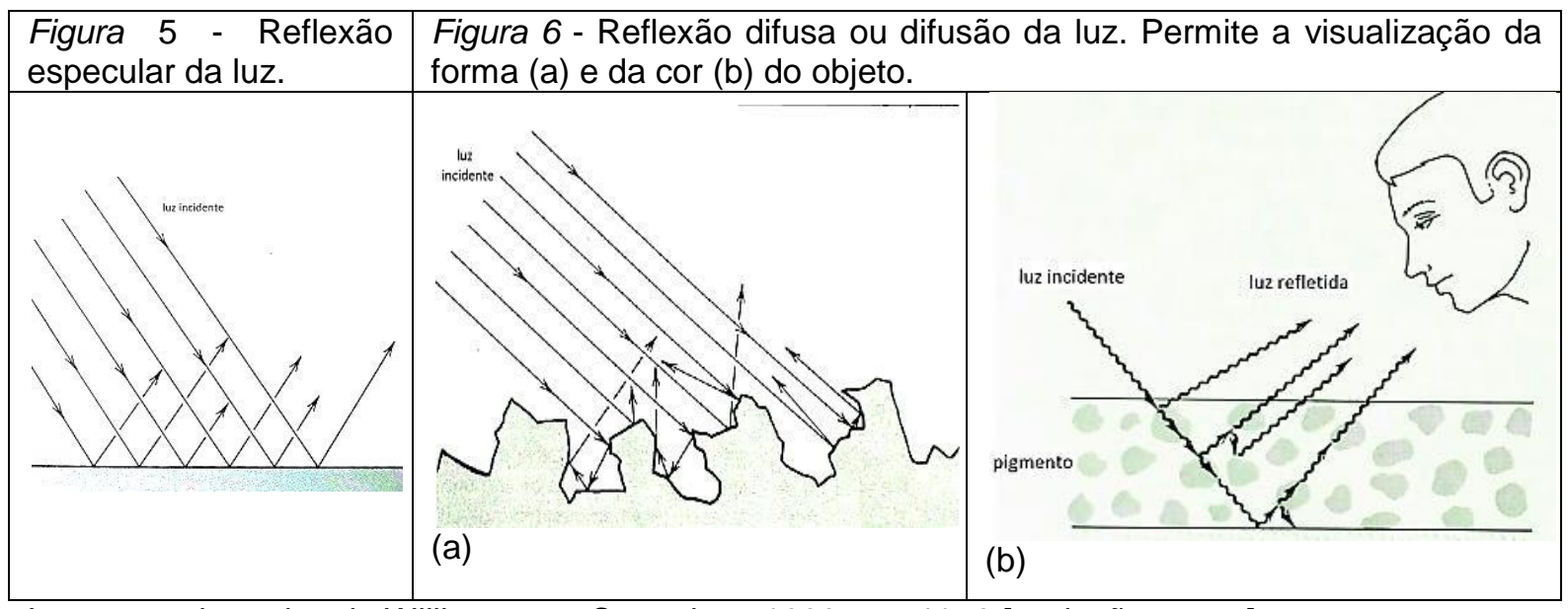

Imagens adaptadas de Williamson e Cummings 1983, pp. 41 -2 [tradução nossa].

Nos quadros protegidos com vidro, há perda de cor das pinturas devido à parcela de reflexão especular da luz no vidro. Por isso, numa pintura observada diretamente, sem a proteção do vidro, as cores são mais vívidas. $O$ vidro antirreflexo absorve para da luz, diminuindo também a intensidade das cores. Muitos quadros do acervo permanente do MASP estão expostos sem o vidro favorecendo a experiência estética do observador.

A superfície pode mudar alterando como a luz reflete. A superfície da água de um lago, por exemplo, se modifica com a presença de vento ou outros agentes que perturbem a água. Ao pintar seu barco ateliê, Claude Monet (1840-1926) representou a imagem do barco na água, resultado da reflexão especular na água e a imagem das árvores da margem deformadas devido às ondulações na água responsáveis pela irregularidade da superfície refletora (reflexão difusa) (figura 7). 
Figura 7 - MONET, Claude. Studio Boat, 1874. Le bateau-atelier, 1874. Óleo sobre tela. KröllerMüller Museum .

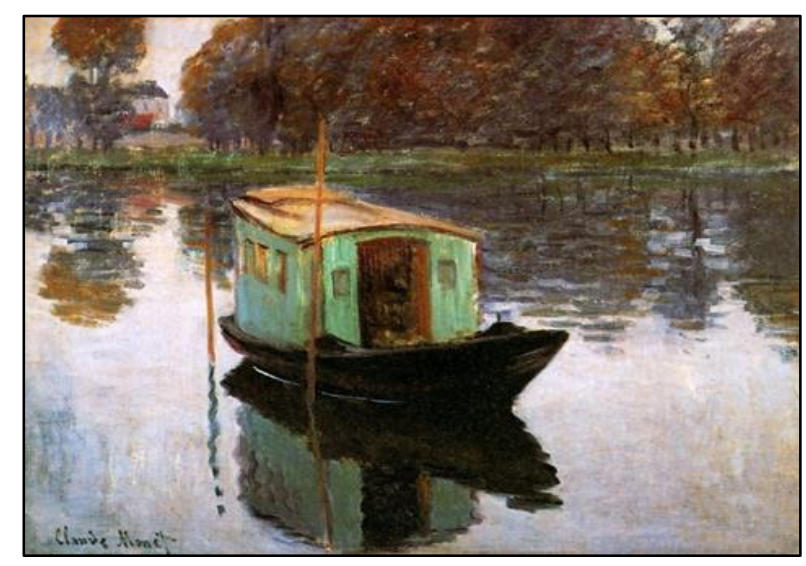

Disponível em https://uploads7.wikiart.org/images/claude-monet/thestudio-boat.jpg!PinterestSmall.jpg[acesso em 30.01.2019].

A reflexão da luz de qualquer superfície é parcialmente difusa e parcialmente especular. As proporções mudam conforme a direção da iluminação e do ângulo de visão. Artistas apreciam esse efeito e incluem áreas sugerindo reflexão especular para enfatizar forma, realçar profundidade, e sugerir a cor da luz iluminando o tema. O pintor grego-espanhol El Greco (1541-1614) aplica áreas generosas de branco para destacar mantos e faces nos retratos (Williamson 1983, p.42) (figura 8). Flávia Ribeiro (São Paulo, 1954), artista plástica paulistana, utiliza o efeito da transparência difusa do papel de seda para suavizar o brilho metálico do ouro e o negro da tinta nanquim que simula uma sombra através da absorção da luz (figura 9). No papel de seda há transmissão parcial da luz refletida pela pintura e difusão da luz pela superfície do papel. 
Figura 8 - El Greco, Anunciação, cerca de 1600 . Óleo sobre tela, $106,5 \times 72,5 \times 3$ cm. MASP, SP

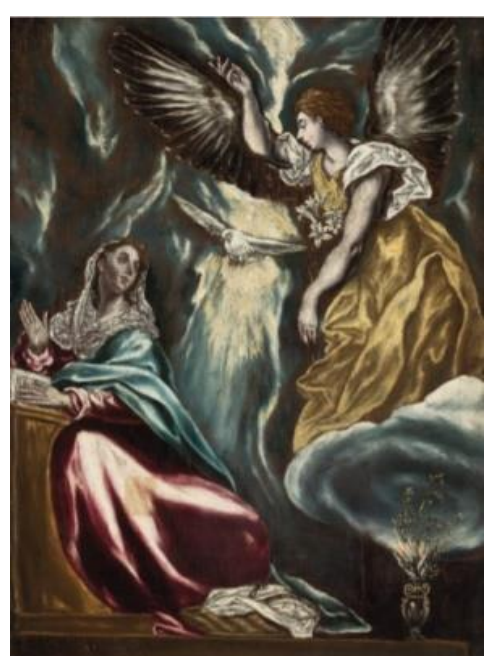

Créditos da fotografia: João Musa. Disponível em https://masp.org.br/acervo/obra/anu nciacao[acesso em 06.03.2019].
Figura 9 - Flávia Ribeiro. Detalhe de obra sem título (da série: Corpos associados). 1995-97, nanquim e pigmento ouro sob papel de seda. MAM, SP.

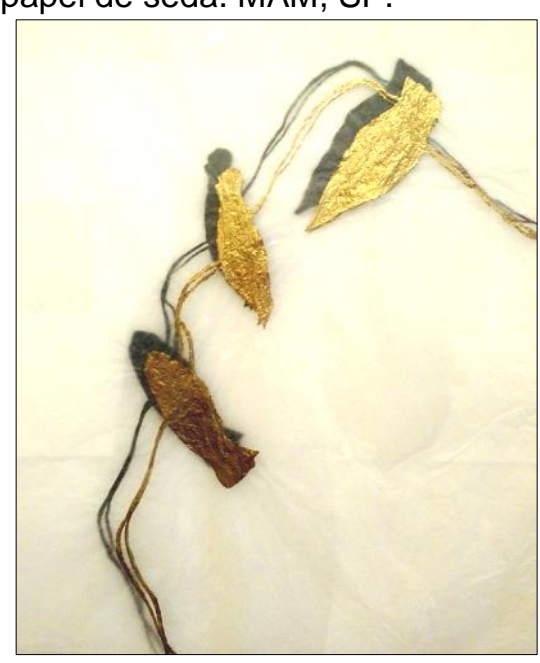

Créditos da fotografia: D. Kohatsu

Em uma superfície mais brilhante há maior reflexão especular. Na figura 10 podemos ver o efeito da reflexão da luz especular e difusa em quantidades diferentes. A tinta fosca ou mate possui menos brilho, predomina a reflexão difusa. A tinta brilhante reflete mais luz especularmente.

Figura 10 - As características da superfície determinam como a luz irá refletir. Abaixo dos primeiros esquemas, exemplificamos o efeito visual em tintas do tipo de reflexão da luz.

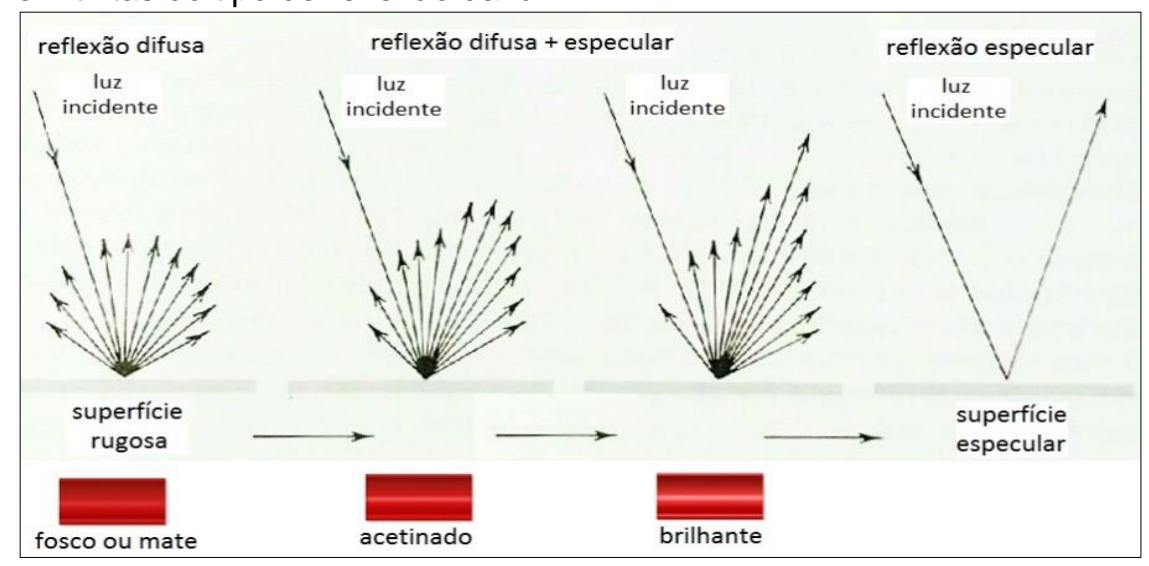

Imagens adaptadas de Willianson, 1983, p. 43 [tradução nossa] e de https://www.tintasepintura.pt/mate-ou-acetinado-qual-escolher// [acesso em 13.03.2019]. 


\subsection{A formação de cor nos objetos}

A cor da maior parte dos objetos do cotidiano é produzida pela absorção seletiva da luz. Os elétrons das moléculas responsáveis pela cor são ressonantes em parte do espectro visível, absorvendo uma faixa de frequências e emitindo outras. Por exemplo, a molécula da clorofila absorve todas as frequências visíveis do espectro da luz solar exceto na faixa da cor verde que é reemitida para o meio como a luz refletida. Folhas jovens tem um tom verde claro porque possuem menos clorofila. Há reemissão de verde e de outras cores que misturadas embranquecem o verde. Os sensores do olho humano de frequências médias captam a radiação na faixa de verde. O indivíduo interpreta a folha é da cor verde (figura 11).

Figura 11 - Percepção da cor verde em uma superfície opaca.

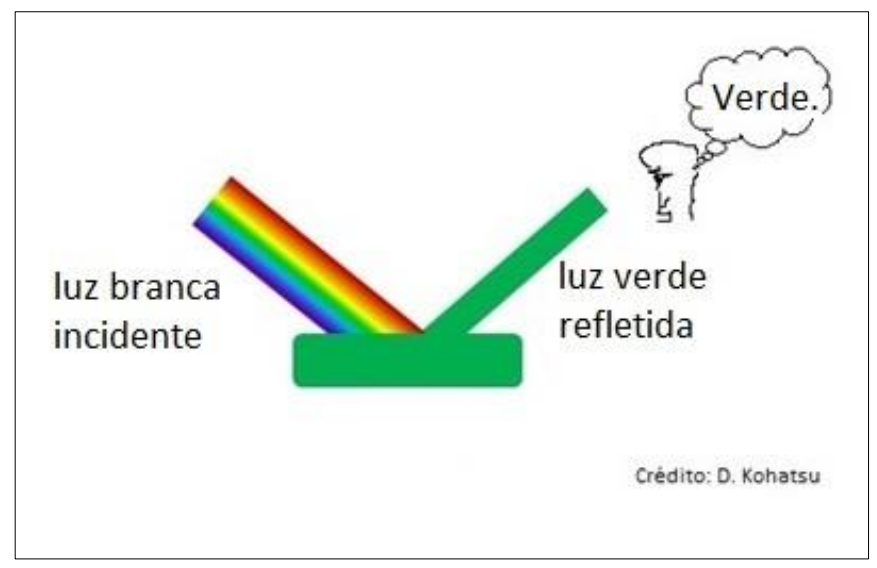

A cor branca resulta da reemissão de uma faixa ampla do espectro que sensibiliza o olho humano de modo a informar o indivíduo que a cor do objeto é branca (figura 12).

Figura 12 - Percepção da cor branca em uma superfície opaca.
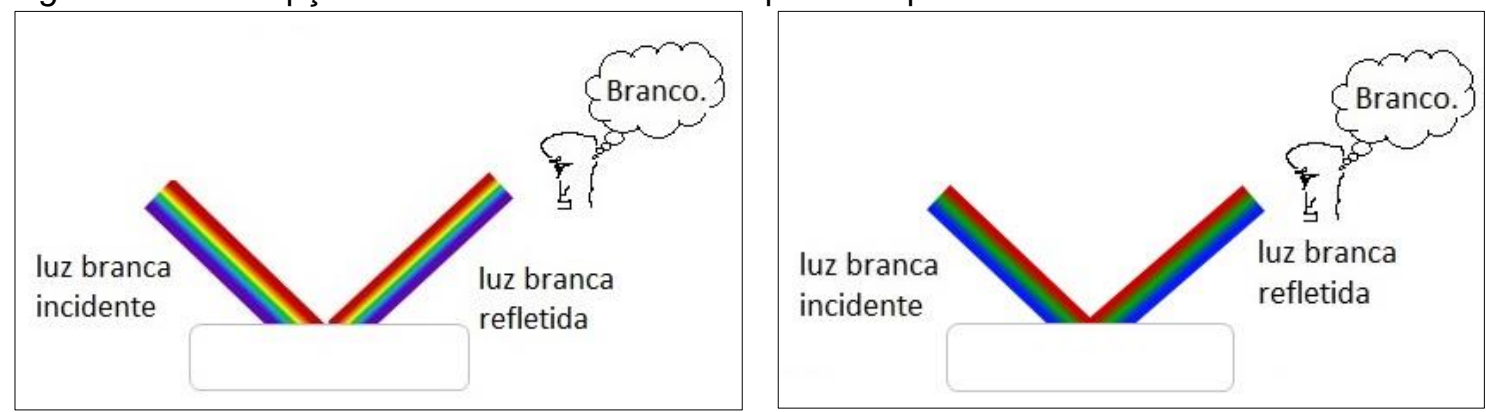

Crédito das imagens: D. Kohatsu 
Quando há absorção total do espectro visível estamos diante do negro ideal. As superfícies pretas do dia a dia refletem um pouco de luz. O olho humano é pouco sensibilizado pela luz, e o indivíduo interpreta a cor do objeto como preta (figura 13). O material de menor refletividade atualmente é o Vantablack $^{13}$, fabricado com nanotubos de carbono, que reflete menos de $0,04 \%$ da luz. A instalação Descida para o limbo, de Anish Kapoor (Índia, 1954), uma cavidade de 2,5 m de profundidade pintada com Vantablack parece plana (figura 14). A variação de intensidade da luz refletida por absorver gera a percepção de profundidade.

Figura 13 - Percepção da cor preta em uma superfície opaca.

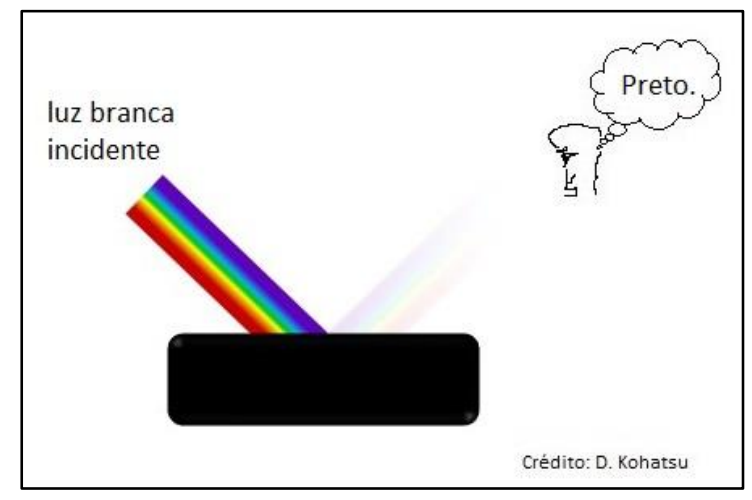

Figura 14 - Anish Kapoor - Descida para o Limbo. Instalação: cimento, tinta preta Vantablack. Museu Serralves, Porto, 06.jul.2018 a 06.jan.2019.

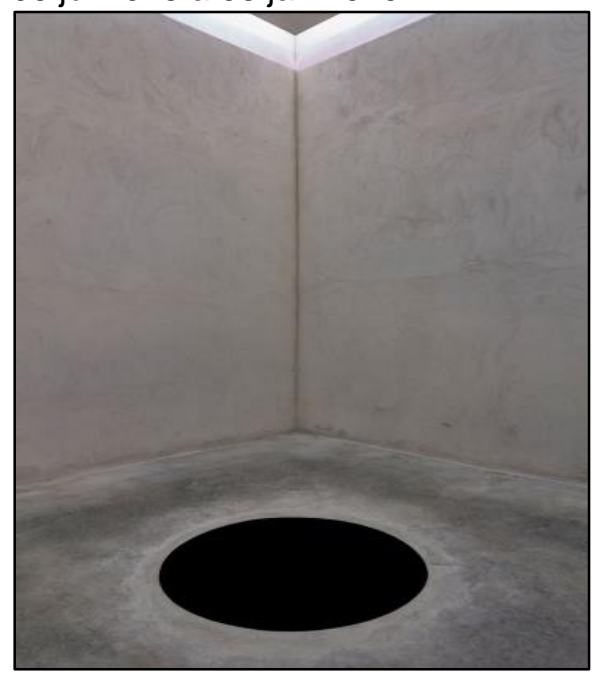

Disponível em https://www.theartnewspaper.com/news/ man-hospitalised-after-falling-in-anishkapoor-installation [acesso em 18.10.2018 ].

O grau de transparência de um objeto depende da quantidade de radiação transmitida. Em objetos transparentes como o vidro, os elétrons são ressonantes na frequência do ultravioleta. A região visível do espectro da luz é transmitida, por isso enxergamos alguém do outro lado do vidro. No vidro colorido há uma absorção seletiva da luz incidente por pigmentos coloridos misturados no vidro. Um vidro vermelho transmite luz na faixa do vermelho e absorve as demais cores do espectro visível. $O$ indivíduo percebe a luz vermelha oriunda de uma superfície semi transparente vermelha. (figura 15).

\footnotetext{
${ }^{13}$ Disponível em https://www.surreynanosystems.com/assets/media/vantablack-vb-a4-data-brochure2016-009-download.pdf [acesso em 01.11.2018].
} 
Figura 15 - Percepção da cor vermelha através da transmissão da luz branco por um filtro vermelho.

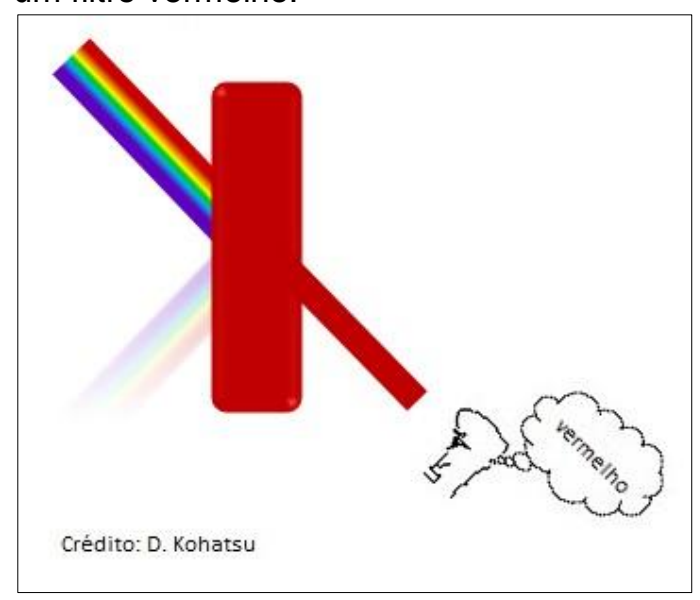

O vitral foi concebido para sua Figura 16 - Vitrais do Teatro municipal de São Paulo. arte se manifestar para um (a) Vista exterior. (b) A beleza do vitral se manifesta observador no interior da construção. A foto do vitral do teatro Municipal de São Paulo ilustra o que acontece com a luz. O observador no interior do teatro capta a luz transmitida através dos vidros coloridos. A predominância de reflexão difusa sobre a especular permite a visão dos contornos das figuras. A arte do vitral se manifesta, quando observado do interior.

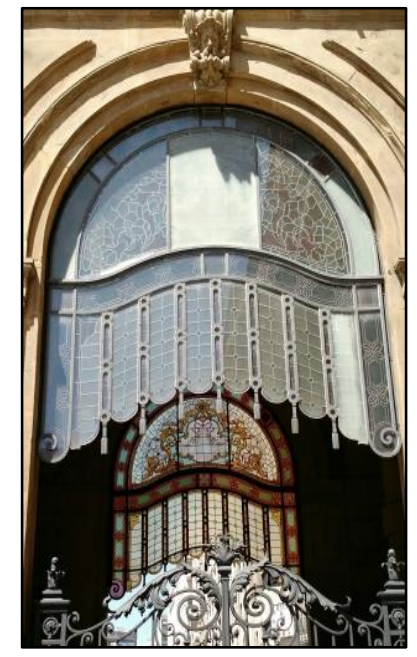

(a)

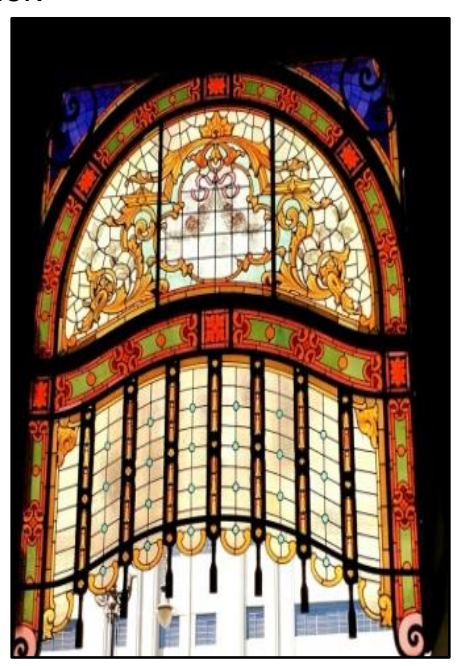

(b)

então, com cores mais saturadas e Crédito das fotos: D. Kohatsu as formas nítidas (figura 16). No lado exterior onde há incidência direta da luz solar, as cores e as formas das figuras desaparecem devido ao excesso de luz refletida (Weisskopf 1968).

A radiação incidente interage com o material constituinte do objeto que reemite uma radiação captada pelo sensor de luz humano, os olhos. 


\subsection{Um modelo de visão de cor}

No ensino básico, adota-se 0 modelo tricromático de Young-Helmhotz para compreender os fenômenos de cor. Simplificadamente, no olho humano a luz entra pela pupila após passar pelo sistema refrativo córnea - cristalino incidindo na retina que contém as células fotorreceptoras cones e bastonetes. O nervo óptico conduz o sinal da retina ao cérebro (figura 17).

Os cones são células fotossensoras responsáveis pela visão cromática. Em geral, o ser humano possui três tipos de células com pigmentos fotoquímicos sensíveis a três faixas de comprimento de onda: curto, médio e longo (figura 18). Os textos didáticos do ensino básico costumam dizer que são

Figura 17 - Diagrama esquemático do olho humano. Corte de seção horizontal do olho direito.

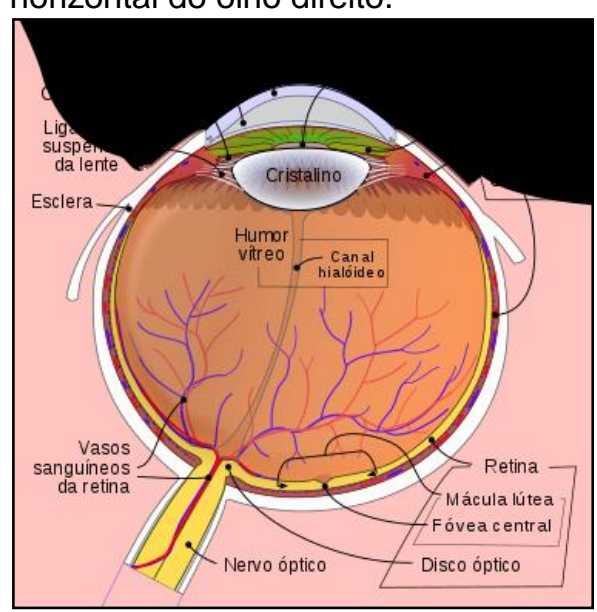

Por Rhcastilhos. And Jmarchn Disponível em https://commons.wikimedia.org/w/ind ex.php?curid=1597954 [acesso em 16.07.2018]. cones sensíveis às cores azul, verde e vermelho. Essa denominação pode induzir a uma compreensão de que cada cone responde somente a um comprimento de onda específico, porém, observando os gráficos de sensibilidade em função do comprimento de onda na figura 18 , percebe-se que os cones são sensíveis a uma faixa do espectro visível. A sensibilidade máxima dos cones é $447 \mathrm{~nm}$ (azul-violeta ondas curtas), $540 \mathrm{~nm}$ (verde - ondas médias) e $577 \mathrm{~nm}$ (amarelo - ondas longas). O espectro das ondas longas é amplo o suficiente para incluir a região de vermelho (Arnheim 2017, p.331). A resposta de cada cone depende do comprimento de onda e da intensidade da radiação luminosa. No processo de evolução, o ser humano desenvolveu menos cones azuis. Há maior sensibilidade para as cores de ondas médias (verde, amarelo) e menor sensibilidade para as cores de comprimento de onda curto (azul, violeta) (figura 19). Os cones concentram-se na fóvea, uma pequena região no centro da retina (figura 17), e necessitam de boa quantidade de luz para seus pigmentos reagirem. Assim, a percepção de cores predomina na visão diurna e frontal.

Quando há baixa luminosidade os bastonetes entram em ação, sendo responsáveis pela visão noturna. O ser humano tem apenas um tipo de bastonete que fornece somente uma informação sobre a quantidade de luminosidade. $O$ 
cérebro interpreta toda a atividade dos bastonetes como tons de cinza, a percepção de claro e escuro - a visão noturna é acromática (Livingstone 2014, p. 33).

A sensibilidade dos bastonetes varia com o comprimento de onda. Sob baixa luminosidade, a cor azul se torna mais visível que a cor vermelha (figura 18).

Figura 18 - Curvas de sensibilidade dos cones e bastonetes do olho humano.

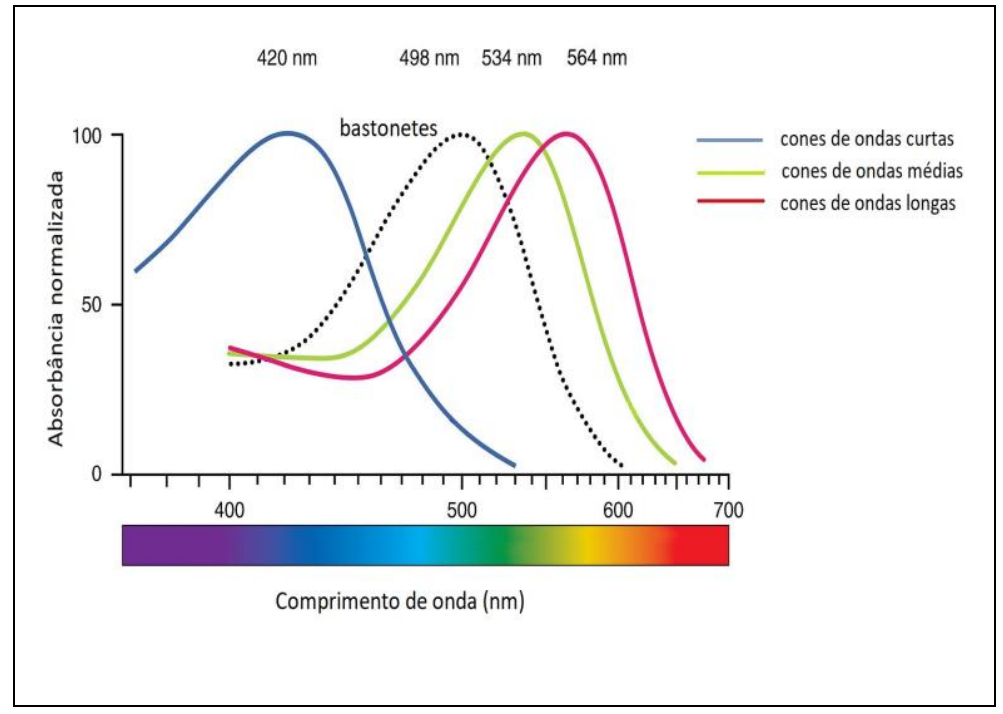

By OpenStax College - Anatomy \& Physiology, Connexions Web site. http://cnx.org/content/col11496/1.6/, Jun 19, 2013., CC BY 3.0, [adaptação e tradução nossa; acesso em 06.02.2019]. Disponível em https://commons. wikimedia.org/w/index.php?curid=30148003

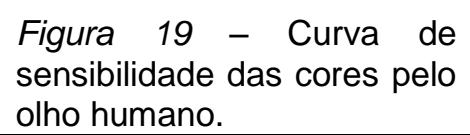
sensibilidade das cores pelo olho humano.

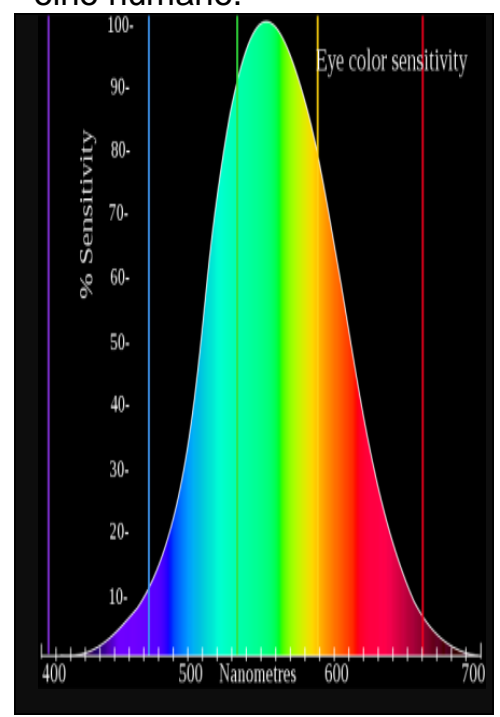

By Skatebiker, vector by Adam Rędzikowski [acesso em 16.07.2018]. Disponível em

https://commons.wikimedia. org/w/index.php?curid=2449 $\underline{2291-}$

As curvas de sensibilidade apresentadas são representações médias da visão humana. A fisiologia do sistema visual varia entre os indivíduos de visão normal. Há uma variação de $25 \%$ na faixa de $350-420 \mathrm{~nm}$, em parte devido aos efeitos do envelhecimento do corpo humano. Há um desenvolvimento gradual da percepção normal de cor do nascimento até a juventude e um declínio a partir de trinta anos em média. $\mathrm{O}$ amarelamento do sistema refrativo, principalmente $\mathrm{o}$ cristalino, aumenta com a idade reduzindo a sensibilidade do olho para comprimentos de onda curtos e médios (Fletcher e Voker 1985, p 68-72). 


\subsection{As cores primárias}

Uma cor primária é uma cor primeira, uma cor fundamental a partir da qual se obtém as demais. Podemos escolher quantas e quais cores primárias desejarmos, mas um sistema eficiente requer o mínimo de cores primárias para criar a maior variedade de cores. "Não há um único conjunto de cores primárias, no entanto algumas cores quando misturadas proverão uma gama maior de cores" (Williamson e Cummins 1983, p.19, tradução nossa).

Newton definiu as cores espectrais, as cores presentes no espectro visível da luz solar ou branca, como as cores primárias. Na tradição newtoniana, são cores espectrais vermelho, alaranjado, amarelo, verde, azul, anil e violeta. As cores não espectrais são branco, preto, os tons de cinza, magenta, púrpura, marrom. O argentino Julio Le Parc ${ }^{14}$ (1928) criou obras com cores espectrais, que podem ser visualizadas na sua página http://www.julioleparc.org/index.html ( não temos autorização para reproduzi-las).

Uma vez que a maioria dos seres humanos tem três tipos de cones, três cores primárias escolhidas adequadamente podem gerar todas as outras cores. Young e Maxwell mostraram que o conjunto de três cores de luz vermelho, verde e azul, em inglês, red, green e blue (RGB), poderiam formar todas as demais cores (Heesen 2015) (Jones 1953, p.38). Este é o modelo tricromático de formação de cores, utilizado pelo sistema RGB em telas de TV, de smartphone, monitores de computador. O nome específico da cor primária não é relevante, uma vez que o nome da cor e o pigmento podem variar, e, sobretudo, a maioria dos cones tem uma faixa ampla de absorção, como vemos na figura 18 (Livingstone 2014).

As cores primárias de impressão e de fotografia são ciano, amarelo e magenta de onde vem o sistema CYMK - ciano, yellow, magenta, black. Na pintura, tradicionalmente, as cores primárias são azul, vermelho e amarelo, mas podemos encontrar ciano, magenta e amarelo dependendo dos pigmentos utilizados.

O pintor holandês Piet Mondrian (1872-1944) pensava que "a arte devia se opor à natureza e de que seu vocabulário deveria ficar restrito às linhas horizontais e verticais e às três cores primárias (Gage 2012, p.27).”

\footnotetext{
${ }^{14} \mathrm{O}$ Instituto Tomie Ohtake realizou uma exposição Julio Le Parc: da Forma à Ação (25.11.2017 a 25.02.2018). O conjunto da obra de Le Parc é um ótimo exemplo da transformação da Ciência na Arte. Ele desenvolveu obras de arte óptica e arte cinética.
} 
Figura 20 - Mondrian, Composition A, 1930, óleo sobre tela, Composition II in Red, Blue, and Yellow, Kunsthaus Zürich, Zürich, $46 \times 46 \mathrm{~cm}$

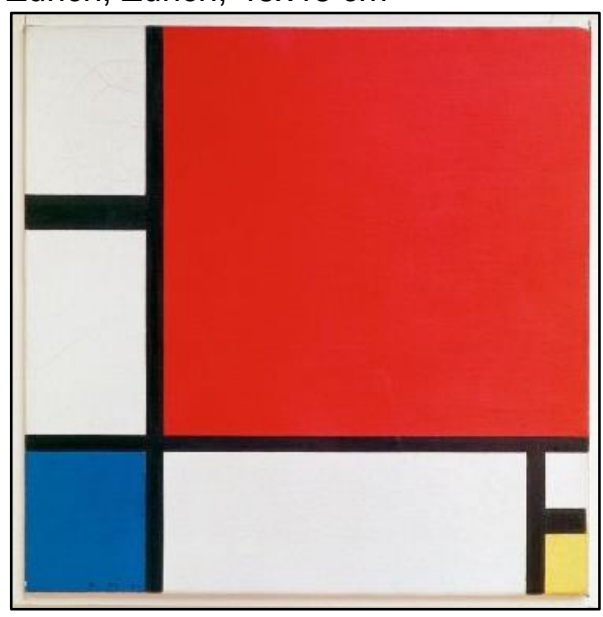

Disponível em:

https://commons.wikimedia.org/wiki/File:Pi et Mondriaan, 1930 -

Mondrian Composition II in Red, Blue, and Yellow.jpg [acesso em 16.07.2018]

\subsection{Mistura de cores}

Há dois processos de mistura de cores, o aditivo e o subtrativo. A mistura aditiva resulta da sobreposição de luzes coloridas. A mistura subtrativa resulta da absorção da luz pelas moléculas dos pigmentos presentes na superfície. Se a superfície do objeto é opaca, a luz não absorvida será refletida. Se a superfície for semitransparente, como um filtro de luz, a luz não absorvida será transmitida. A subtração produz sensações de cor com o que sobra depois da absorção (Arnheim 2017).

A mistura das cores primárias duas a duas gera as cores secundárias. A soma das três cores primárias nos dois processos aditivo e subtrativo resulta numa cor não espectral neutra: branco, a soma das luzes coloridas do processo aditivo, ou preto, a ausência de luz, a total absorção da luz no processo subtrativo.

A cor complementar é a cor oposta à cor primária. A soma de uma cor primária com sua complementar resulta numa cor acromática - branco (processo aditivo) ou preto (processo subtrativo). Por exemplo, misturando-se luz azul e luz amarela nas proporções corretas, a cor luz resultante é branca. Misturando-se tinta azul com tinta amarela, nas devidas proporções, obtém-se uma tinta preta. 
Figura 20 - Diagramas de cores primárias e as cores resultantes das misturas das cores.

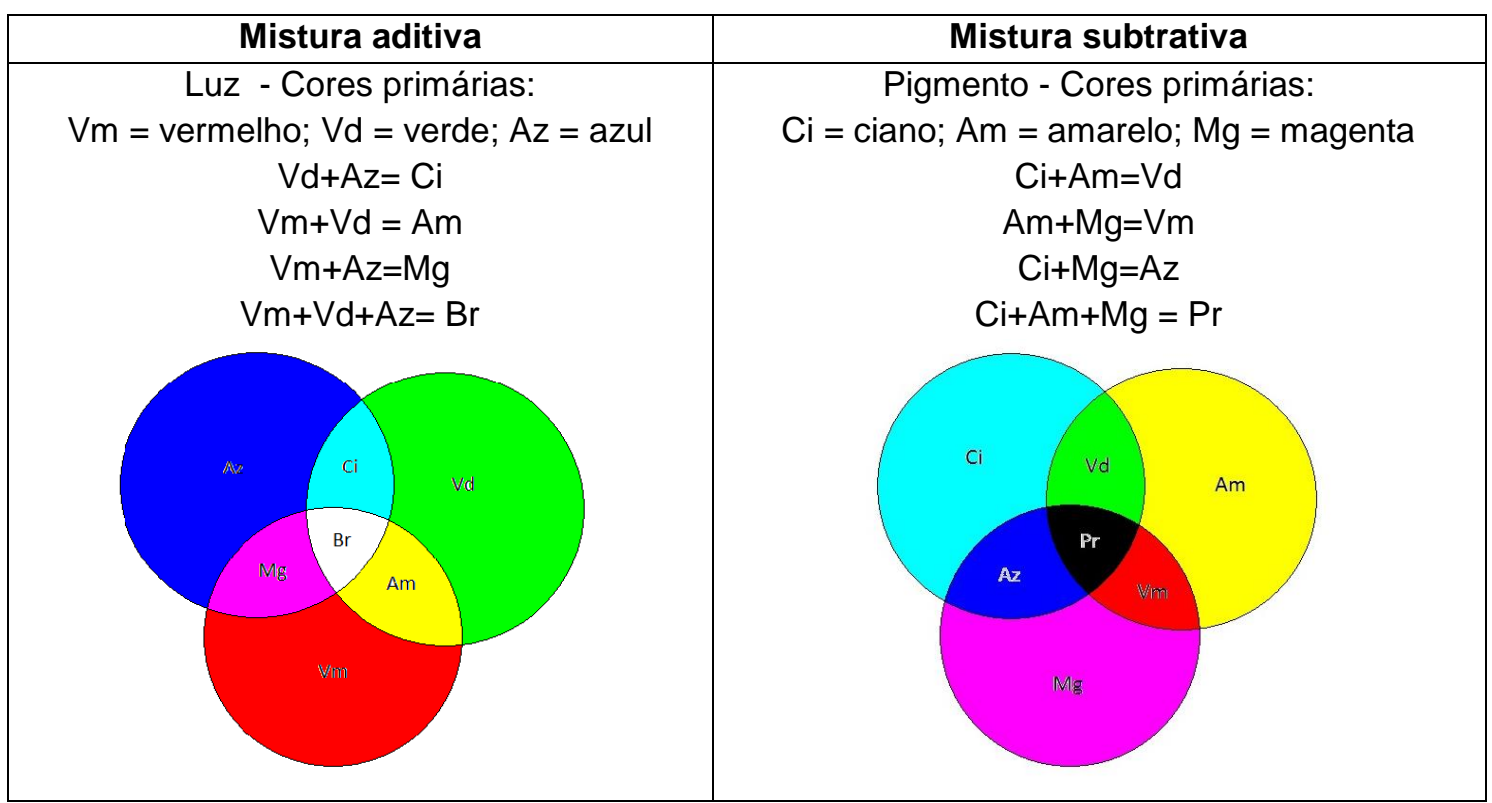

Crédito das imagens: D. Kohatsu

A mistura aditiva de cores pode ser classificada conforme o método de adição de cores. O método de superposição mistura dois ou mais feixes de luz colorida simultaneamente como nas produções teatrais ou na demonstração de sombras coloridas (figura 21) (Williamson e Cummins, 1983, p.21-2).

Figura 21- Sombras coloridas

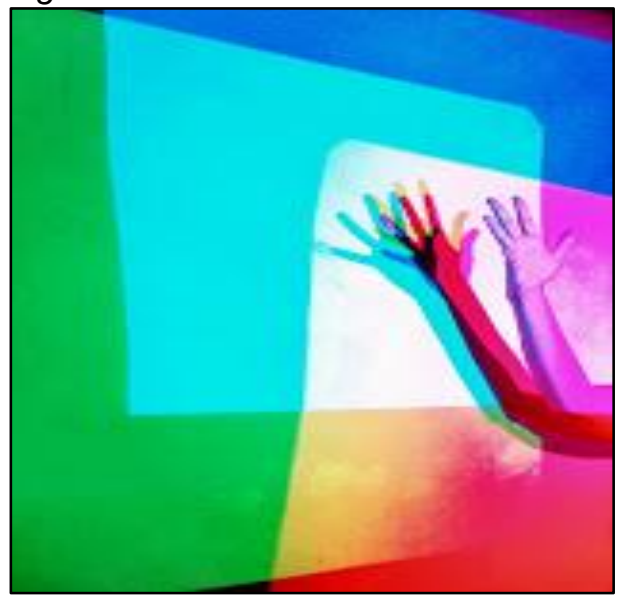

Crédito da imagem: D. Kohatsu 
$\mathrm{Na}$ mistura partitiva as fontes luminosas das cores não são percebidas individualmente, elas são suficientemente pequenas e próximas para dar a impressão de uma imagem colorida única. Na tela do smatphone e/ou computador há pequenos pontos luminosos de luzes vermelho, verde e azul (figura 22).

Figura 22 - Sistema RGB. Método aditivo partitivo de cores. Na tela do computador ou do smartphone, feixes de luz vermelho, verde e azul são emitidos por pontos invisíveis a olho nu, misturando-se em quantidades diferentes formando uma gama enorme de cores.

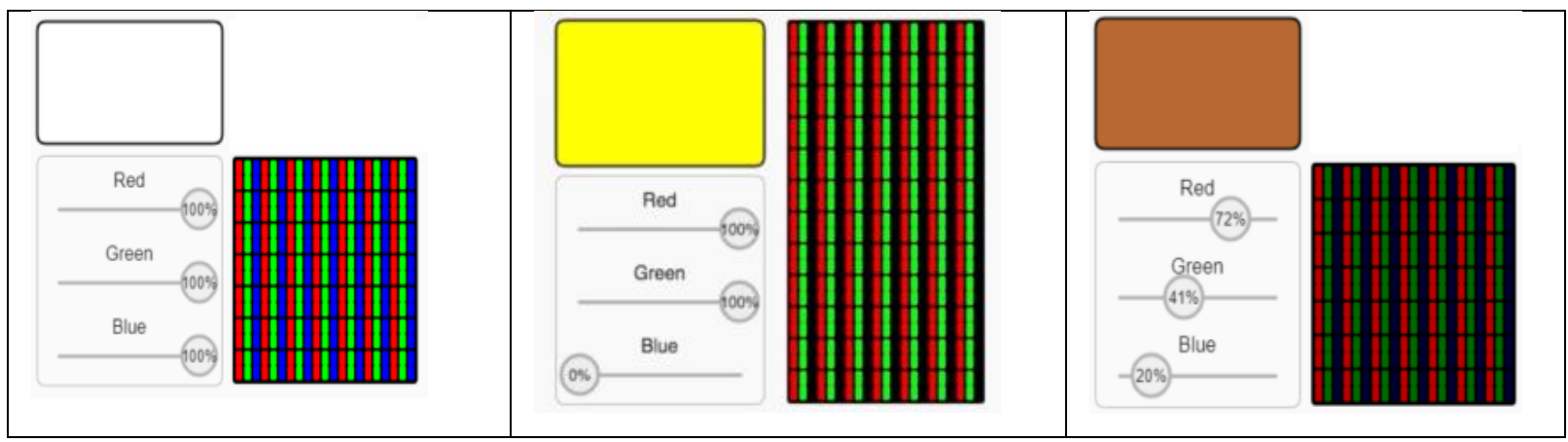

llustrações produzidas em Pixar in a Box. Color Science. Disponível em https://www.khanacademy.org/partner-content/pixar/color/color-101/e/rgb-color [acesso em 30.06.2019].

Na impressão a cores, pontos justapostos de cores ciano, magenta, amarelo e preto refletem a luz misturando-se num processo aditivo partitivo. Com o auxílio de uma lente convergente é possível visualizar os pequenos pontos formadores de imagem na tela do smatphone ou numa folha impressa. O Pontilhismo, movimento de pintura do final do século XIX, utiliza uma técnica pintando pequenos pontos coloridos cuja luz refletida se mistura pela adição partitiva. Os principais representantes do Pontilhismo são os franceses Georges Seurat (1859-1891) (figura 23) e Paul Signac (1863-1935) (Williamson e Cummins, 1983, p.21-2). 
Figura 23 - Seurat, A Sunday on La Grande Jatte,1884 - 1886, óleo sobre tela, Art Institute of Chicago, Chicago, $207.5 \times 308.1 \mathrm{~cm}$

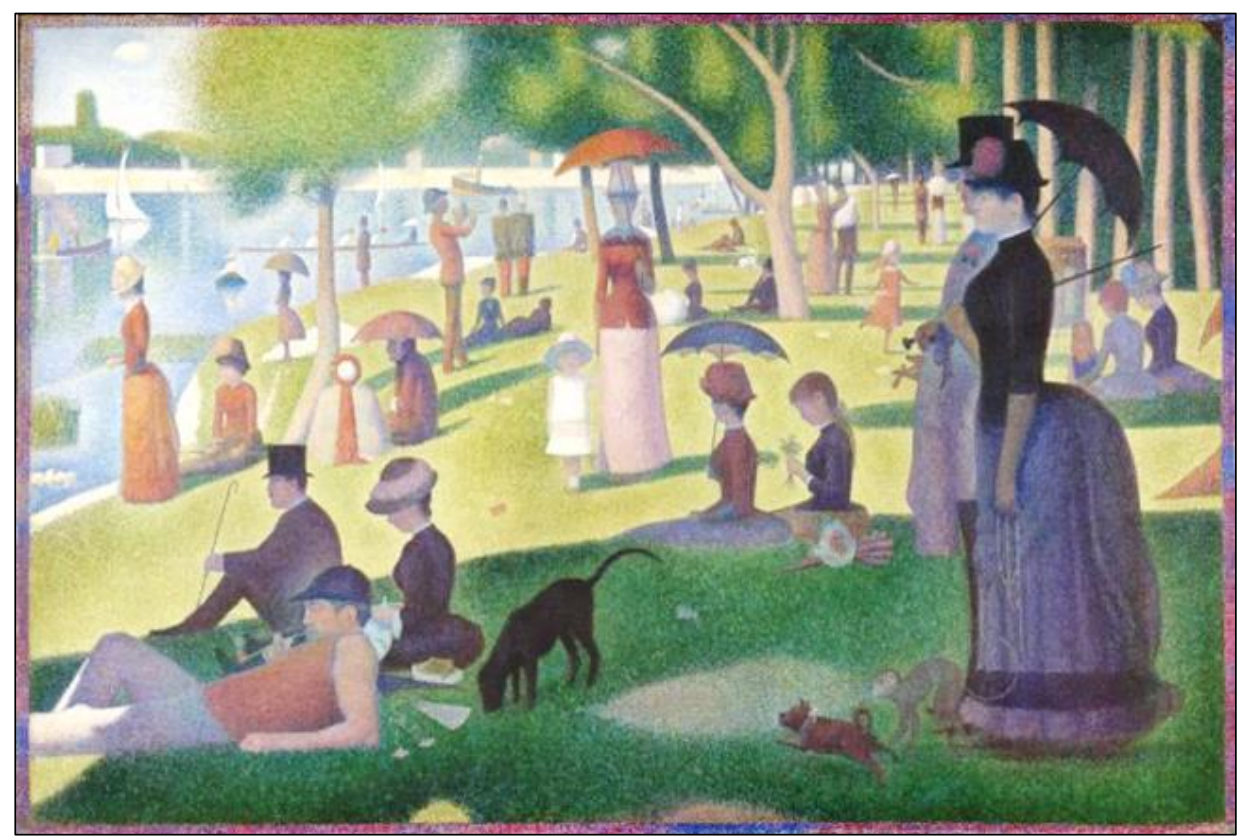

Disponível em https://www.wikiart.org/en/georges-seurat/study-for-a-sundayon-la-grande-jatte-1885 [acesso em 30.06.2019].

Figura 24 - Disco pintado com as sete cores espectrais. Do lado esquerdo girando em baixa velocidade por um peão e à direita em alta rotação girando por um motor.
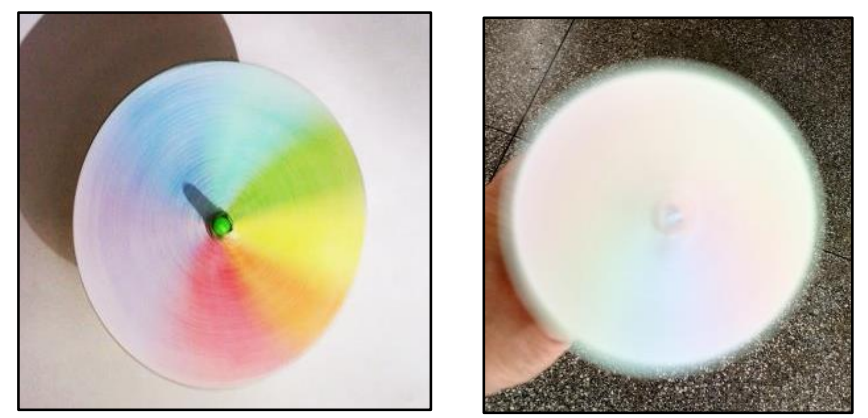

Crédito das imagens: D. Kohatsu

No método de adição por superposição e partitivo a mistura da luz é espacial. Num terceiro método aditivo, a mistura de cores é temporal. Quando duas cores ou mais piscam rapidamente em alternância sobre uma tela, o sistema visual humano não pode seguir os flashes individualmente, a percepção é similar a de mistura aditiva. Efeito análogo é obtido quando um disco com seções pintadas em várias cores gira rapidamente (Williamson e Cummins, 1983, p.22). Uma parcela da energia luminosa incidente é absorvida pelos pigmentos, é a luz refletida pelas cores 
pintadas que se mistura quando o disco gira. Quando pintado com as sete cores espectrais, o tradicional "disco de Newton ${ }^{15}$ ", é comum obter-se cinza ou uma cor clara e não o branco. Aumentando-se a intensidade da luz incidente sobre o disco rotativo ou aumentando-se a velocidade de rotação, a cor obtida pela mistura aditiva torna-se mais clara (figura 24).

\subsection{A percepção da cor}

Como vimos, Goethe contestou a teoria newtoniana das cores devido à subjetividade da percepção das cores. Podemos entender a cor como resultado de um estímulo visual produzido por uma energia radiante, a luz, sobre a retina e da percepção desse estímulo (Jones 1953, pp. 221-2). Sensação e percepção não são sinônimos mas eventos interdependentes. A sensação é gerada pelo estímulo a um órgão sensorial. Como interpretamos esse sinal, depende da nossa percepção. Sensações constituem a matéria prima da experiência humana e percepções são os produtos manufaturados pela cultura humana (Gibson 1950, p. 12). A cor de um objeto depende da energia radiante emitida por ele, da captação desse sinal pelo sensor, o olho, e da decodificação e interpretação desse sinal pelo cérebro. A percepção da cor de um objeto depende:

(i) da absorção seletiva - os pigmentos presentes no objeto determinam a absorbância de uma gama de frequências da radiação incidente. A parte da radiação não absorvida é reemitida por reflexão ou transmissão para o olho gerando um estímulo visual.

(ii) da distribuição espectral da energia radiante incidente - o tipo de luz incidente na superfície do objeto.

(iii) das funções psicofísicas da visão humana.

De acordo com o aspecto da realidade que se deseja descrever, a cor pode se referir a uma propriedade de um objeto característica do material - por exemplo, a cor preta com propriedades ideais possui teria $0 \%$ de transparência, $0 \%$ de reflectância e 100 \% de absorbância; uma característica dos raios de luz ou da radiação eletromagnética, como a frequência ou o comprimento de onda; ou uma classe de sensações luminosas, como interpretação do cérebro - a percepção visual

${ }^{15}$ O que popularmente é denominado de "disco de Newton" originalmente era um diagrama de mistura de cores. Ptolomeu no século II d.C, havia descrito a mistura das cores por variação temporal (Gage 2012, p. 20). 
resultado do sistema olho-cérebro (Nassau 2012). Em função disso, a cor percebida por um indivíduo depende de três atributos:

- Matiz - comprimento de onda ou frequência dominante. O que chamamos de "verde", "vermelho", por exemplo.

- Saturação - relativo à intensidade ou pureza da cor. A cor pura observada no espectro da luz tem saturação máxima. Tons mais claros, mais próximos do branco ou cinza são menos saturados.

- Brilho ${ }^{16}$ - refere-se à percepção da intensidade de luz. Os vários tons de cinza podem ser descritos somente pelo brilho - do preto, ausência total de luz, ao branco brilhante. Como não há matiz, a cor cinza é acromática. (Willianson e Cummings1983, p. 17)

$\mathrm{Na}$ foto da figura 25, as flores são da mesma espécie são vistas em tonalidades diferentes. Todas possuem o mesmo matiz, pois todas absorvem a mesma faixa de frequência da luz solar; as mais claras possuem maior brilho porque a intensidade de luz refletida é maior.

Figura 25 - As flores da região mais iluminada parecem mais claras.

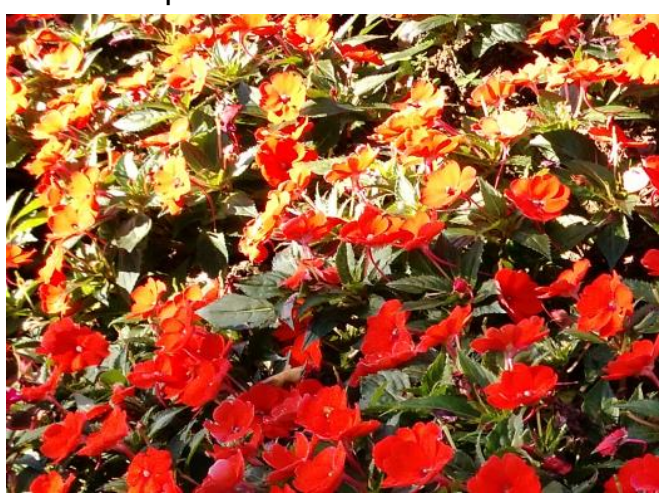

Crédito da imagem: D. Kohatsu

A aptidão do cérebro humano para categorizar sensações e para receber bilhões de estímulos caóticos, diferentes de pessoa para pessoa, garante a criação de um mundo perceptual e semântico próprio de cada indivíduo, de onde emergem o pensamento e a linguagem (Meyer 2002, p.17).

Diferentes línguas possuem diferentes nomes para distinguir cores. Brent Berlin e Paul Kay (1969) conduziram uma pesquisa em linguística e antropologia sobre a influência cultural na nomenclatura de cores. Concluíram que povos iletrados e mais primitivos possuem menos termos básicos de cores, no mínimo têm duas

\footnotetext{
${ }^{16}$ Este terceiro atributo da cor é denominado por valor ou luminância conforme o autor. Joseph Aubers, no livro A Interação das Cores, elucida essa polêmica. Valor representa uma medida precisa da luminosidade da cor no Sistema de Munsell. Nos outros sistemas, não tem um significado preciso. (...) 'O uso descuidado de 'valor', em particular no que diz respeito à luminosidade (...) tornou essa palavra inútil enquanto recurso de medição. Em seu lugar, portanto, usamos 'intensidade de luz' como um termo auto-explicativo (Albers 2009, p. 99).
} 
categorias para distinguir claro e escuro. Todas as línguas contêm termos para branco e preto. A terceira cor que surge é vermelho, seguida de amarelou ou verde, e azul. Nas sociedades modernas industriais, há 11 termos - branco, preto, cinza, vermelho, amarelo, verde, azul, marrom, violeta, rosa, laranja. Nas línguas eslavas, há 12 termos para cores, distingue-se azul claro e azul escuro (Hardyn 2013). Na tabela a seguir, vemos a nomenclatura das cores encontradas nas línguas estudadas por Berlin e Kay.

Tabela 1 - Termos para cores encontrados em pesquisa linguística por Berlin e Kay (1969, p.2- 3)

\begin{tabular}{|c|l|}
\hline $\begin{array}{c}\text { Número } \\
\text { de termos }\end{array}$ & \multicolumn{1}{|c|}{ Nomenclatura das cores } \\
\hline 2 & Branco e preto \\
\hline 3 & Branco, preto e vermelho \\
\hline 4 & Branco, preto, vermelho, amarelo ou verde \\
\hline 5 & Branco, preto, vermelho, amarelo e verde \\
\hline 6 & Branco, preto, vermelho, amarelo, verde e azul \\
\hline 7 & $\begin{array}{l}\text { Branco, preto, vermelho, amarelo, verde, azul e } \\
\text { marrom }\end{array}$ \\
\hline 8 ou mais & $\begin{array}{l}\text { Branco, preto, vermelho, amarelo, verde, azul, } \\
\text { marrom e violeta, rosa, laranja, cinza ou } \\
\text { combinações dessas cores. }\end{array}$ \\
\hline
\end{tabular}

A ausência de nomes para categorias de cores, bem como a presença de subcategorias para outras cores decorre da influência cultural. $O$ interesse que as pessoas apresentam por certas cores e a falta de interesse em relação a outras, diferenças observadas na importância prática que as diferentes cores possuem em diferentes culturas. Por exemplo, populações próximas ao Ártico contêm muitos termos para nuanças de branco, expressões para se referirem a diferentes tipo de neve, um fato de importância prática. Já nuanças de vermelho e verde não possuem nenhuma importância. (LURIA, 1975/2017, p. 47).

A visão genotípica é um fenômeno comum da espécie resultado do desenvolvimento ontogenético, garantido pela natureza física do estímulo da energia radiante e por uma especialização do cérebro. A visão fenotípica é uma percepção individual, que varia em razão das influências do meio e da aprendizagem (Meyer 2002, p.71). A percepção da cor é um processo complexo que depende de fatores físico-químicos, biológicos e do desenvolvimento histórico cultural do indivíduo. 


\section{A PERSPECTIVA HISTÓRICO-CULTURAL}

Liev S. Vigotski ${ }^{17}$ (1896-1934) conhecido pela obra em psicologia genética teórico-cultural ${ }^{18}$, possuía ampla formação humanística e cultural. Graduou-se em Direito e também estudou e atuou profissionalmente em diferentes áreas da psicologia, filosofia, história, arte, literatura, teatro, neurologia, linguística, sociologia, teologia. A formação multidisciplinar de Vigotski permitiu-Ihe unir várias linhas de investigação em uma abordagem integradora dos fenômenos sociais, semióticos e psicológicos (Werstch 1985). Encontramos em suas obras fundamentação para o desenvolvimento e análise de uma sequência de ensino aprendizagem integrando Arte e Ciência por suas concepções de desenvolvimento das funções cognitivas que envolvem a relação entre pensamento e linguagem, a construção dos conceitos científicos e os processos de aprendizagem.

\subsection{Uma visão geral do pensamento de Vigotski}

Embora tenha realizado estudos em muitas áreas, o programa de pesquisa de Vigostski e seus colaboradores concentrou-se em questões de desenvolvimento cognitivo e de ensino-aprendizagem, sistematizado na teoria histórico cultural, também denominada teoria sócio histórica. "Estudar alguma coisa historicamente significa estudá-la no processo de mudança..." (Vigotski 1988, p.74. itálico do autor). Nos processos de desenvolvimento estuda-se os momentos de transição, onde o indivíduo se depara com a necessidade de adaptação e/ou se confronta com um problema. A dimensão sócio-cultural tem papel central na concepção de Vigotski. O desenvolvimento cognitivo do sujeito acontece através da mediação por elementos semióticos (signos e símbolos) e outros indivíduos.

Compreende-se a teoria histórico-cultural dos processos psicológicos de Vigotski através da inter-relação de três eixos estruturantes: (i) o método genético ${ }^{20}$

\footnotetext{
${ }^{17}$ Por uma questão de uniformidade adotaremos a grafia Vigostski mesmo quando na obra original grafa-se Vygotsky. Ver explicação no apêndice I. versão da tradução do russo para o inglês, mantido em algumas edições na língua

${ }_{18}$ Frequentemente se ouve da teoria psicológica da atividade desenvolvida pela escola VigotskiLeontiev-Luria. Este nome é adequado quando a abordagem se concentrar mais em problemas de ação e atividade do que em problemas de signo, significado, símbolo e consciência (Davidov, V.V., Zinchenko, V.P., 1985, prefácio p. XI). Preferimos manter teoria histórico-cultural por nos focarmos nas obras de Vigotski em si.

${ }^{20}$ Genético, do gr. genētikós, "que gera, que produz, relativo às forças produtoras"( Houaiss, 2019) [acesso em 01.06.2019]. Disponível em https://houaiss.uol.com.br/pub/apps/www/v33/html/index.php\#1
} 
ou de desenvolvimento; (ii) a origem social da funções cognitivas ${ }^{21}$ superiores; e (iii) os processos cognitivos superiore se desenvolvem através da mediação de instrumentos externos (signos, símbolos e objetos) (Werstch 1996, p. 9) ${ }^{22}$ (Ardila, 2016).

O método genético explica a formação dos processos cognitivos humanos a partir de sua origem e desenvolvimento da evolução da espécie humana (a filogênese), do desenvolvimento histórico (a sociogênese) e do indivíduo (a ontogênese). Os pontos cruciais no percurso evolutivo são o uso de ferramentas pelos macacos antropoides e o trabalho vinculado ao desenvolvimento da fala humana e outros signos psicológicos. O desenvolvimento do indivíduo depende da maturação das funções biológicas e da aquisição de habilidades, modos de comportamento e pensamento culturais (Vigotski e Luria 1996, p. 52).

O macaco possui pensamento não verbal que independe da fala, uma forma biológica de inteligência prática presente em várias espécies. $\mathrm{O}$ uso de racional de instrumentos pelo macaco antropoide (chipanzé) distingue-o de outros animais. Köehler $^{23}$ realizou experimentos com chipanzés constatando sua capacidade de utilizar um instrumento em resolução de problema. Para alcançar uma banana, um chipanzé alfa observou os objetos disponíveis - caixas e varas - e após testá-los, alcançou a banana. Os outros membros do grupo observando o chipanzé alfa, imitaram seu comportamento, aprendendo a utilizar um instrumento. Os resultados de Köehler levaram Vigotski a concluir que (i) quando um indivíduo está diante de um problema, há aumento de atividade cerebral impulsionando-o a testar os instrumentos presentes em seu campo visual; (ii) a reação intelectual do chipanzé é resposta a um obstáculo que impede a realização de seu desejo; (iii) o instrumento adquire significado quando é compreendido dentro de uma estrutura; (iv) a ação pode acontecer por imitação dos outros membros do grupo.

O instrumento como mediador de uma ação, a descoberta do significado do instrumento através da vivência, a imitação, o problema como mobilizador da ação e do pensamento ressurgem quando Vigotski aborda o desenvolvimento dos

\footnotetext{
21 Embora Vigotski nunca tenha utilizado o termo cognitivo, ele "poderia ser considerado um cognitivista, na medida em que se preocupou com a investigação dos processos internos relacionados à aquisição, organização e uso do conhecimento(...). Os termos utilizados por Vigotski para designar processos que denominamos cognitivos são 'funções mentais' e 'consciência'." (Oliveira, 1992, p.75-6)

${ }_{22}$ In Vygotsky, L.S. e Luria, A.S. Estudos sobre a história do comportamento.

${ }^{23}$ Wolfgang Köhler (1887-1967), psicólogo alemão que investigou o comportamento de chipanzés.
} 
processos cognitivos humanos e a aprendizagem. A utilização pelo chipanzé de objetos limitados ao seu campo visual não the permite generalizar o uso do instrumento. Essa ideia remete ao pensamento concreto da criança e de pessoas iletradas ou limitadas sem capacidade de abstração.

A capacidade de ação dos animais limitada ao seu campo visual, a ausência de fala, a incapacidade de transmissão do uso instrumento para outras gerações e, principalmente, o fato do instrumento não ser essencial para sua adaptação ao meio diferenciam o macaco do homem. No processo evolutivo, o desenvolvimento do cérebro, do intelecto, e da mão como órgão de instrumento de ação, a invenção e o uso consciente de ferramentas marca o início do trabalho pelo homem.

\subsection{A mediação e o desenvolvimento das funções cognitivas}

As ferramentas de trabalho surgem para solucionar um problema externo adequando o ambiente às necessidades do indivíduo e do grupo social. Os signos, instrumentos psicológicos ou culturais, são criados para solucionar um problema interno (lembrar, contar, comunicar etc.) consequência da formação de grupos sociais. O homem modifica o ambiente externo através de atividades mediadas por ferramentas de trabalho. Ele se transforma através dos instrumentos físicos e culturais (signos e símbolos) que cria e transmite culturalmente a seus descendentes. Vigotski (1988 p.44, p.59-60) define signo como "estímulos artificiais, ou autogerados. [...] O signo age como um instrumento da atividade psicológica de maneira análoga ao papel de um instrumento no trabalho." Palavras, números, fórmulas são exemplos de signos, agentes mediadores da formação das funções cognitivas superiores.

As funções cognitivas se desenvolvem conforme a maturação biológica do indivíduo e sua interação com o meio externo. "As funções elementares têm como característica fundamental o fato de serem total e diretamente determinadas pela estimulação ambiental. No caso das funções superiores, a característica essencial é a estimulação autogerada" (Vigotski 1988, p. 44). No ambiente natural, o indivíduo desenvolve as funções cognitivas elementares. No ambiente cultural, a atividade mediada por signos possibilita o desenvolvimento das funções cognitivas elementares para superiores. Por exemplo, da memória natural para memória lógica, da atenção e percepção involuntária para atenção e percepção voluntária, do pensamento concreto para o pensamento abstrato. As funções cognitivas 
elementares caracterizam-se pelo controle exercido pelo ambiente natural, ausência de realização consciente, origens individuais, e ausência de mediação por instrumentos psicológicos. As funções cognitivas superiores são tipicamente humanas. Caracterizam-se por processos voluntários, realização consciente, mecanismos intencionais, origem e natureza social, e mediação por instrumentos psicológicos (signos) (Wertsch 1985, p.27)(Oliveira 1992, p.79).

$O$ instrumento mediador é o elo entre a atividade sujeito e o objeto de conhecimento e do sujeito para o objeto. As funções cognitivas se desenvolvem no percurso de ida e volta. Vigotski enfatizou mediadores simbólicos apropriados pelas crianças no contexto de atividades socioculturais específicas, das quais a mais importante considerava ser a educação formal. Pesquisadores russos consideram além da mediação simbólica ou cultural, a mediação humana e a mediação em uma forma de atividade de aprendizagem organizada. Cada cultura tem seus próprios instrumentos psicológicos e situações de apropriação desses instrumentos. A essência da educação reside em fornecer aos estudantes os instrumentos adequados ao desenvolvimento das funções cognitivas (Kozulin 2003, pp.15, 17). Ao longo dos anos, diversas pesquisas realizadas em diferentes países convergem na questão do impacto cultural em processos de cognição humana (Ardila 2016).

\subsubsection{A mediação cultural na Física}

A física enquanto domínio cultural possui sua própria linguagem. A aprendizagem da física implica na internalização de instrumentos cognitivos específicos. O contexto cultural da física pode emergir na realização de atividades que visam a integração de objetivos conceituais, epistêmicos e sociais.

Como veremos adiante, a palavra é um grande mediador do pensamento. A compreensão conceitual, a interpretação da linguagem matemáticas, a leitura, a discussão, a elaboração de textos são práticas que promovem o uso da linguagem e deveriam ser mais disseminadas nas aulas de física.

\subsubsection{O mediador humano}

O caminho do objeto até a criança e desta até o objeto passa através de outra pessoa. Essa estrutura humana complexa é o produto de um processo de desenvolvimento profundamente enraizado nas ligações entre história individual e história social (Vigotski 1988, p.33). 
Na perspectiva de Vigotski, o mediador humano tem um papel fundamental uma vez que a formação do indivíduo depende do seu contexto social. A capacidade cognitiva é desenvolvida, ela não é inata. "Todas as funções superiores originam-se das relações reais entre indivíduos humanos" (Vigotski 1988, p.64). tipo de processo social que Vigotski enfatiza, o interpsicológico, envolve grupos pequenos de indivíduos, frequentemente díades, engajados numa interação social concreta (Wertsch 1985, p.60).

$\mathrm{Na}$ escola, o professor é mediador da atividade de aprendizagem, enquanto responsável pelo currículo de seu curso, pela escolha de abordagem didática, procedimentos, interações em sala de aula. O professor viabiliza o ambiente de aprendizagem. Ele prepara material para a aula, orienta, apresenta o conceito, sistematiza o conhecimento; é modelo a ser imitado ${ }^{24}$ (Gaspar 2014 pp.203-204, 210).

A importância do mediador humano aparecerá na questão da imitação e da colaboração na aprendizagem que abordaremos adiante na seção sobre a zona de desenvolvimento imediato.

\subsection{A internalização do signo}

O desenvolvimento pleno das capacidade cognitivas do indivíduo só ocorre através de agentes mediadores inseridos no seu meio sócio cultural pelo processo de internalização do signo. Este processo consiste na reconstrução interna da atividade externa, na transformação de um processo interpessoal (interpsicológico) para o intrapessoal (intrapsicológico). "Todas as funções no desenvolvimento da criança aparecem duas vezes: primeiro no nível social, depois no nível individual" (Vigotski 1988, p.64). A internalização envolve um processo da transformação do fenômeno social num fenômeno psicológico. Vigotski viu a realidade social desempenhando um papel primordial na determinação da natureza do funcionamento intrapsicológico (Wertsch 1985, p. 63).

A internalização enquanto processo de assimilação do signo constitui-se ao longo do desenvolvimento psicológico através de transformações qualitativas próprias do indivíduo. Na formação dos processos cognitivos superiores, as

\footnotetext{
${ }^{24}$ A imitação tem um papel importante no desenvolvimento do indivíduo. Discutiremos sobre isso ao abordarmos a ideia de zona de desenvolvimento imediato.
} 
atividades realizadas passam a ser executadas internamente com consciência, constituindo um processo de construção da própria consciência do indivíduo.

A concepção da formação da consciência pelo meio social tem raízes na teoria marxista, como escreve Alexander Romanovich Luria (1902-1977), o principal colaborador de Vigotski. Alinhando-se com o pensamento de Marx e Lenin, a psicologia soviética sustenta que a consciência é a forma mais elevada de reflexo da realidade: ela não é dada a priori, nem é imutável e passiva, mas sim formada pela atividade e usada pelos homens para orientá-los no ambiente, não apenas adaptando-se a certas condições, mas também reestruturando-se (Luria 2017, p. 27). A consciência forma-se de fora para dentro através da atividade do sujeito com signos e símbolos, enquanto formas de representação da realidade externa, presentes no ambiente cultural. Cada cultura tem seus próprios instrumentos psicológicos e situações de apropriação desses instrumentos. A essência da educação reside em fornecer aos estudantes os instrumentos adequados ao desenvolvimento das funções cognitivas (Kozulin 2003, p.16).

\subsection{Pensamento e linguagem}

A linguagem ${ }^{25}$ é o instrumento mediador mais significativo no processo de desenvolvimento humano. Ela possui função comunicativa e cognitiva. A forma de comunicação reflete a operação mental realizada.

A relação entre pensamento e linguagem modifica-se no processo de desenvolvimento tanto quantitativa quanto qualitativamente. [...] No pensamento do homem adulto, a relação entre intelecto e linguagem não é constante e idêntica para todas as funções e formas de atividade intelectual e verbalizada (Vigotski 2009, pp.111,114). Na teoria histórico cultural, define-se "intelecto como o comportamento planejado, organizado, orientado para a solução de algumas tarefas complexas" (Luria 1996, p.208). Nesta perspectiva, há formas de pensamento não verbal, atividade intelectual sem fala. A inteligência prática dos animais é ricamente ilustrada pela atividade de animais como a habilidade dos pássaros na contrução de

\footnotetext{
${ }^{25}$ Linguagem, fala, discurso, conversa, capacidade de falar são traduções de riétch. Vigotski parte da ideia de linguagem egocêntrica de Piaget para chegar na concepção de linguagem/discurso interior. Em a "Formação Social da Mente", traduzido para o português do inglês, encontramos linguagem expressa enquanto fala externa e fala interna (1988, p.65). Em "A Construção do Pensamento e da Linguagem" traduzido do russo para o português, o tradutor Paulo Bezerra manteve o termo linguagem interior em função da coerência terminológica (2009, p.IX). Entendemos que a opção por "fala" na tradução de riétch, pretende explicitar a ação da linguagem falada, a emissão de sonora de palavras.
} 
ninhos ou na ação dos chipanzés que utilizaram a vara para alcançar a banana no experimento de Koeler. No ser humano, as primeiras vocalizações do bebê e da criança, expressões vocais associadas a movimento ou a reações emocionais são exemplos de situações onde há emissão de som não intelectualizada. Uma pesquisa da escola alemã de Würzburg demonstrou que o trabalho mental intenso pode ocorrer sem palavras e sem imagens, e até incoscientemente, quando a pessoa não é capaz de explicar como tal pensamento Ihe veio à mente (Luria 1996, p. 209). $\mathrm{Na}$ cultura escolar podemos encontrar ações como decorar uma fórmula que podem gerar expressões orais sem processamento cognitivo.

A linguagem enquanto instrumento de mediação do pensamento pode ou não se adquirir função cognitiva.

[...] no adulto a fusão de pensamento e linguagem é uma manifestação parcial que só vigora e se aplica no campo do pensamento verbalizado, ao passo que outros campos do pensamento não-verbalizado e da linguagem não-intelectual sofrem influência apenas distante e indireta dessa fusão e não mantêm com ela nenhuma relação causal (Vigotski 2009, p. 140).

O pensamendo verbalizado vinculado ao desenvolvimento da linguagem tem importância fundamental na educação devido à relação direta com a constituição dos processos cognitivos superiores, o desenvolvimento do conceito (o significado da palavra) do conceito científico (o conceito aprendido na escola) e da linguagem interior.

\subsubsection{A formação do conceito}

A palavra (o signo) dotada de significado se torna o conceito, mediador do ambiente interno e externo do indivíduo. $O$ processo de formação de conceito é atrelado ao desenvolvimento do pensamento concreto ao pensamento abstrato.

Os psicolinguistas diferenciam três elementos da palavra: o som, o significado e a imagem. A imagem é o vínculo entre o som e o significado. Qualquer palavra no momento de seu aparecimento, possui uma imagem, ligada ao seu contexto. No processo de desenvolvimento da linguagem, a imagem vai se extinguindo, e a palavra conserva apenas o significado e o som (Vigotski 2003, p.170). A palavraimagem está associada ao pensamento concreto. Nas pesquisas com povos iletrados do Ubezquistão, Luria constatou que o sistema semântico de nomeação de cores reflete a experiência de vida prática dos indivíduos. A ausência de nomes para categorias de cores, bem como a presença de subcategorias para outras cores 
decorre da influência cultural, o interesse que as pessoas apresentam por certas cores e a falta de interesse em relação a outras. A pobreza ou riqueza linguística de termos de cores são resultado das diferenças observadas na importância prática que as diferentes cores possuem em diferentes culturas. Por exemplo, populações próximas ao Ártico contêm muitos termos para nuanças de branco, expressões para se referirem a diferentes tipo de neve, um fato de importância prática. Já nuanças de vermelho e verde não possuem nenhuma importância (Luria 2017, p. 47). O pensamento primitivo é um pensamento visual. As necessidades técnicas e da vida são a fonte verdadeira da característica da linguagem primitiva. Cor de tabaco, cor de palha, cor de cereja resultam de uma necessidade de contato direto com objetos e dos requisitos da atividade técnica (Vigotski 1996, pp. 131-2).

A criança (ou um adulto iletrado) pensa qualitativamente diferente do adulto culturalmente formado. Quando está começando a ser apreendida, uma nova palavra é uma palavra imatura, no início do seu desenvolvimento. $O$ amadurecimento da palavra vem com o desenvolvimento interno do seu significado. A formação do conceito se desenvolve em três estágios: o sincretismo ou pensamento por imagens sincréticas, o pensamento por complexos e o pensamento por conceitos. O desenvolvimento dos conceitos não é linear nem limitado ao desenvolvimento biológico apesar de Vigotski indicar as faixas etária do desenvolvimento de cada estágio. Quando Vigotski escreve sobre "idade" entendese como uma categoria psicológica e não apenas uma característica temporal ou um período de desenvolvimento. As faixas etárias são entendidas como uma construção histórica e material. Histórica porque as funções são construídas através da história de práticas humanas; material porque as funções são desenvolvidas como uma consequência de tarefas e interações com outros (Chaiklin 2003, p.48).

\subsubsection{Sincretismo}

A fase pré-escolar caracteriza-se pelo pensamento egocêntrico. Segundo Piaget, o comportamento da criança caracteriza-se pela dissociação do mundo, na concentração sobre seu próprio eu. Ela fica completamente imersa em si. Frequentemente, a fala da criança não é utilizada para fins sociais de comunicação recíproca, é uma fala dirigida para si (Luria 1996, p. 162).

O significado da palavra nesta fase caracteriza-se pelo pensamento sincrético ou sincretismo. A criança atribui significado a um amontoado de objetos através de 
vínculos subjetivos estabelecidos conforme a sua percepção. A palavra atribuída a um objeto pode ser a mesma para a criança e para o adulto sendo o suficiente para ambos se comunicarem. Porém, o significado da palavra é parcial ou até distinto para a criança (Vigotski 2009, p.176). Conceitos que só têm um aspecto externo em comum são agrupados. A criança substitui um conceito desconhecido por outro familiar. As substituições do desconhecido pelo compreensível, as misturas de significados encontram-se na fala da criança. Uma observação incompleta pode ser suficiente para uma inferência correspondente mesmo que inadequada. $O$ pensamento pré-cultural infantil é um reflexo imediato do mundo percebido pela criança. O pensamento da criança infere de um episódio para outro, orientado, a cada vez, por novos atributos que prendem a atenção infantil (Luria 1996, pp.172-3).

A criança percebe o mundo como ele é da sua própria perspectiva. É uma percepção holística de um mundo concreto que existe dentro do seu campo visual e naquele momento. Ela percebe o objeto a partir do aspecto que the seja mais familiar e the afeta diretamente. Estabelece vínculos subjetivos entre os objetos. Não se preocupa com as conexões entre cada um dos quadros que percebe, nem com a sistematização do mundo e de seus fenômenos. A lógica de relações causais é substituída por uma lógica primitiva de pensamento sem conexão causal ou misturando causa e efeito ou hierarquização (Luria, 1996). O sincretismo constitui um mecanismo de adaptação da criança ao mundo.

\subsubsection{Pensamento por complexo}

Depois do amontoado de objetos do pensamento sincrético, no início da fase escolar, por volta de sete anos, a criança desenvolve o pensamento por complexos. A criança começa a comparar objetos baseada nas impressões visuais. Ela pode agrupar os objetos através de atributos objetivos concretos gráficos (cor, forma) ou funcionais numa lógica associativa sem hierarquia, categorização ou relação causal. Ao comparar dois objetos a partir de propriedades isoladas, ela perde de vista 0 atributo originalmente selecionado e muda de um atributo a outro. Os objetos são agrupados sem um vínculo objetivo, generalizante e unificador em torno de uma palavra. Cada objeto é incluido no grupo de maneira individual formando um complexo de objetos. A estrutura lógica do complexo sugere uma família onde os membros são identificados pelo sobrenome em comum mas mantém sua individualidade, cada um participa de maneira particular, e podendo mudar de 
posição hierárquica. Por exemplo, a mãe pode ser filha ou tia dependendo do contexto do subnúcleo familiar (Luria 1996, pp.168-9; 2017, p.83). Os objetos são agrupados em categorias conforme critérios subjetivos momentâneos. Isso gera uma diversidade de vínculos, uma multiplicidade de traços concretos que é "policrômica, desordenada, pouco sistematizada e não reduzida à unidade, embora esteja baseada em vínculos objetivos" (Vigotski 2009, p. 182).

No pensamento por complexo, a palavra é um signo de representação coletiva - identifica um grupo. Neste estágio, o pensamento da criança coerente e objetivo é estabelecido por um vínculo concreto entre os objetos que se revelam na experiência imediata. Embora a objetividade esteja presente no pensamento por complexo, a palavra contém um caráter subjetivo pois o critério de vínculo entre os objetos é temporal e escolhido pela criança, que pode se comunicar com o adulto através de uma palavra com significado interno distinto do conceito compreendido pelo indivíduo cultural.

O pseudoconceito é último estágio do pensamento por complexo, marcando a transição do pensamento concreto para o pensamento abstrato. Na interação com o adulto, a criança recebe a linguagem pronta dos adultos. A palavra é o meio de comunicação entre ambos. Isso não garante que as operações cognitivas por trás da palavra sejam as mesmas. No desenvolvimento intelectual da criança, primeiro ela começa aplicar e operar com o conceito na prática, a partir do pensamento concreto, e depois ela o assimila abstratamente, formando o conceito. A criança concebe 0 significado (conceito) do signo (palavra) por operações cognitivas distintas do adulto, daí o termo pseudoconceito (Vigotski 2009, pp.196-8). Embora o pensamento do adulto tenha acesso à formação de conceitos e opere com eles, nem sempre isso acontece. "Do ponto de vista dialético, os conceitos não são conceitos propriamente ditos na forma como se encontram no nosso discurso cotidiano. São antes "noções gerais sobre as coisas" (Vigotski 2009, p. 218).

No contexto escolar, é comum o aluno ou até mesmo o professor dar "explicações ou respostas baseadas em denominações simples, encadeamentos ou correlações que, apesar de serem etapas importantes de aquisição da compreensão conceitual, estão ainda distantes dela" (Gaspar 2014, p.122). O desenvolvimento limita-se ao pensamento concreto.

No pensamento por complexo "as palavras da criança coincidem com as palavras do adulto em sua referencialidade concreta, ou seja, referem-se aos 
mesmos objetos, a um mesmo círculo de fenômenos. Entretanto, não coincidem em seu significado" (Vigotski 2009, p. 210).

O sincretismo e o pensamento por complexos são manifestações do pensamento concreto limitado à realidade existente no campo visual da criança e de suas impressões subjetivas. O desenvolvimento do pensamento concreto para o abstrato depende da mudança do significado da palavra construído no referencial concreto, limitado ao contexto experiencial da criança, para um referencial universal. O significado da palavra torna-se único e geral formando-se o conceito.

\subsubsection{Pensamento conceitual}

O último estágio do desenvolvimento infantil, o pensamento por conceitos constitui-se por três fases: a generalização por semelhança, o conceito potencial, o conceito verdadeiro.

$\mathrm{Na}$ fase da generalização por semelhança, em condições experimentais, a criança generaliza a partir de um modelo que lhe é dado. Ela observa objetos diferentes, discrimina atributos essenciais de semelhança e cria a generalização. $O$ ato de discriminar e generalizar é superior à elaboração do pseudoconceito.

$\mathrm{Na}$ fase do conceito potencial, a criança generaliza depois de reunir um grupo de objetos segundo um atributo comum. O vínculo uniforme e estável entre os objetos diferencia o conceito potencial do pensamento por complexo onde as associações se baseiam em vínculos instáveis. O conceito potencial é de natureza concreta e funcional: concreta porque a criança generaliza a partir de um referencial concreto; e funcional porque a criança explica o significado de uma palavra dizendo o que o objeto nomeado por essa palavra pode fazer (Vigotski 2009, pp. 222-5).

A formação do conceito verdadeiro requer análise e síntese da realidade vivenciada, pressupõe a generalização de determinados elementos concretos da experiência. A análise da experiência requer a discriminação, a abstração e o isolamento de determinados elementos, além da habilidade de examinar os elementos discriminados e abstraídos fora do vínculo concreto e factual. O conceito surge quando os atributos abstraídos tornam a se sintetizar na palavra.

Um conceito expresso por uma palavra representa uma generalização, mas os significados das palavras evoluem. Quando uma palavra nova, ligada a um determinado significado, é apreendida pela criança, o seu desenvolvimento está apenas começando. No início ela é uma generalização mais elementar. À medida 
que a criança se desenvolve, a palavra é substituída por uma generalização de um tipo cada vez mais elevado, culminando no processo da formação do conceito (Vigotski 2009, p. 220).

$\mathrm{Na}$ transição do pensamento concreto para o abstrato, o adolescente aplica $\mathrm{o}$ conceito, a palavra, corretamente em uma situação concreta, porém com dificuldade em defini-lo. No caminho inverso, do abstrato para o concreto, ao transferir o conceito a uma nova situação concreta também há muita dificuldade por requerer o uso consciente do conceito. $O$ pensamento do indivíduo oscila entre 0 pensamento por complexos e o pensamento por conceitos. Ele aplica a palavra como conceito e a define como complexo (Vigotski 2009, pp.228-31).

No processo de aprendizado do conceito, o indivíduo não percorre a via lógica do mais particular para o mais geral; e sim do geral para o particular. $\mathrm{O}$ indivíduo assimila a palavra "flor", que é mais genérica, antes da palavra "rosa", que é mais particular (Vigotski 2009, p. 360). O conceito geral está mais próximo do pensamento por complexo, onde a palavra é uma representação coletiva de um grupo de objetos. A subordinação do conceito específico ao geral, a classificação, atrela-se ao desenvolvimento da percepção, da comparação, da categorização, ou seja, uma complexidade de funções cognitivas.

Geneticamente, a palavra primeiro possui função indicativa por indicar um atributo do objeto. A palavra adquire função significativa quando sintetiza, generaliza e significa as impressões concretas. O significado da palavra se torna conceito quando é assimilado e transferido para outras situações. "A formação dos conceitos surge sempre no processo de solução de algum problema que se coloca para o pensamento do adolescente. Só como resultado da solução desse problema surge o conceito " (Vigotski 2009, p.237, itálico nosso).

O conceito ou o significado das palavra é aprendido através de um processo de mudanças das estruturas cognitivas complexas que requer o desenvolvimento de toda uma série de funções como a atenção arbitrária, a memória lógica, a abstração, a comparação e a discriminação que não são simplesmente assimilados. "Por isso, do ponto de vista psicológico dificilmente poderia haver dúvida quanto à total inconsistência da concepção segundo a qual os conceitos são apreendidos pela criança em forma pronta no processo de aprendizagem escolar e assimilados da mesma maneira como se assimila uma habilidade intelectual qualquer (Vigotski, 2009, pp.246-7). 


\subsubsection{A formação do conceito científico}

Segundo Vigotski (2009), o conceito científico se aprende através da cultura escolar. Dentro da cultura cotidiana, o indivíduo aprende o conceito espontâneo. O desenvolvimento do conceito científico começa pela sua definição verbal, por operações que pressupõem a aplicação não espontânea desse conceito. $O$ conceito científico nasce de um pensamento abstrato, efetivando-se no mundo concreto através de ações conscientes do indivíduo. O conceito espontâneo se forma na situação concreta e evolui para a abstração. Apesar de caminharem em sentidos opostos, o desenvolvimento de ambos conceitos se inter-relaciona. "O desenvolvimento do conceito espontâneo da criança deve atingir um determinado nível para que a criança possa aprender o conceito científico e tomar consciência dele [...]" (Vigotski 2009, p. 290). Os conceitos espontâneos mediam a relação entre o objeto de aprendizagem e o conceito científico. A compreensão do significado de uma palavra facilita a criação de relações com outras palavras. $O$ surgimento de um novo conceito se baseia na transformação do conceito anterior.

"Todo conceito é uma generalização" (Vigotski 2009, p.359). Generalização implica em tomada de consciência e sistematização de conceitos. O conceito científico insere-se num sistema de conceitos. Na criança, os conceitos gerais surgem frequentemente antes dos particulares. Ela apreende a palavra "flor" antes da palavra "rosa" sem diferenciar ou hierarquizar esses dois conceitos. Quando generaliza o conceito "flor", muda a relação entre "flor" e "rosa" e outros conceitos subordinados. "A tomada de consciência dos conceitos se realiza através da formação de um sistema de conceitos, baseado em determinadas relações recíprocas de generalidades (Vigotski 2009, pp.292, 295, aspas do autor).

O aprendizado dos conceitos científicos propicia a evolução dos processos cognitivos superiores por envolver o emprego consciente da palavra, a reestruturação e a ressignificação do conceito espontâneo. Uma vez assimilado, o conceito científico começa a mediar o pensamento e a resolução de problemas. $\mathrm{O}$ pensamento do indivíduo se torna independente da experiência pessoal. Ele desenvolve a habilidade de operar no nível do pensamento lógico-formal (Karpov 2003, p.66). Os conceitos científicos capacitam os seres humanos a realizarem a atividade cognitiva com independência máxima do contexto concreto. Representam o ponto final na descontextualização dos instrumentos mediadores. Isto significa que 
os mecanismos semióticos evoluidos sócio-historicamente passam a desempenhar um papel cada vez mais importante nos processos cognitivos, enquanto há uma diminuição do papel do contexto concreto (Wertsch 1985, pp. 103, 105).

Em pesquisa realizada por Luria com indivíduos iletrados e com pouco letramento do Uzbesquistão ${ }^{27}$, percebe-se que a cultura escolarizada favorece 0 desenvolvimento da abstração. O pensamento conceitual envolve a expansão da atividade cognitiva. Uma pessoa capaz de pensamento abstrato reflete sobre 0 mundo externo mais profundamente. Chega a conclusões e inferências a respeito do fenômeno percebido, tomando por base não só sua experiência pessoal, mas também os esquemas de pensamento lógico que objetivamente se formam em um estágio avançado do desenvolvimento da atividade cognitiva (Luria 2017, p.157).

O desenvolvimento pleno das capacidades cognitivas do indivíduo vincula-se à formação do conceito. O ambiente cultural onde o indivíduo cresce é fator essencial no seu desenvolvimento. $O$ aprendizado do conceito científico é aprendido através de um processo sistematizado que considera a mudança das estruturas internas da criança. Um método de ensino que privilegia a memorização e a mecanização, a simples transmissão do conceito do professor para o aluno, pode levar à assimilação da palavra mas não à formação do conceito. $\mathrm{O}$ indivíduo "capta mais de memória que de pensamento e sente-se impotente diante de qualquer tentativa de emprego consciente do conhecimento assimilado" (Vigotski 2009, p. 247).

Vigotski distingue o sentido e significado da palavra conforme sua contextualização e variabilidade. O conceito espontâneo está mais próximo do sentido da palavra; o conceito científico carrega o significado da palavra. O sentido da palavra é variável, contextual, polissêmico. O significado da palavra adquire aspectos subjetivos ao incorporar nuances intelectuais e afetivos subjacentes ao contexto da palavra. "O sentido real de cada palavra é determinado por toda a riqueza dos momentos existentes na consciência e relacionados àquilo que está expresso por uma determinada palavra" (Vigotski 2009, p.466). O significado é um dos sentidos da palavra. O significado é invariável, objetivo, descontextualizado. $\mathrm{Na}$ arte predomina o uso do sentido da palavra, na ciência o signfificado.

\footnotetext{
${ }^{27}$ A descrição da pesquisa está no livro O desenvolvimento cognitivo, A.R. LURIA
} 


\subsection{Linguagem social, egocêntrica e interior}

A linguagem se desenvolve conforme a necessidade de adaptação ao mundo exterior. Vigotski distingue três categorias da linguagem: a social, a egocêntrica e a interior. A social tem função comunicativa; a linguagem egocêntrica e a interior têm função cognitiva.

Primeira surge a linguagem social pela necessidade de comunicação da criança, sendo uma linguagem exterior, sonora, dialógica, dirigida ao outro. A linguagem egocêntrica se manifesta quando a criança se encontra diante de um problema. Assim como a linguagem social, é uma linguagem exterior e sonora, mas monológica, uma fala para si, a oralização do pensamento durante a execução de uma atividade prática. Por conter características da linguagem social e da linguagem interior, e'uma linguagem de transição. Externamente a linguagem egocêntrica tem características da linguagem social e internamente da linguagem interior.

Diante de um problema, a criança fala sobre as possibilidades de resolução, planeja ações e ao mesmo tempo as executa. Experimentalmente observou-se que quando a dificuldade do problema aumenta, a criança aumenta a fala egocêntrica também. A linguagem egocêntrica assume a função de operação de planejamento durante a atividade prática da criança. Planejar implica em pensar ações futuras, fora do campo visual imediato da criança, um processo de abstração. A necessidade da externalização do pensamento caracteriza uma etapa transitória para o pensamento verbal. A linguagem egocêntrica é uma linguagem interior por sua função de estruturação do pensamento e ao mesmo tempo ainda é fisiologicamente externa (Vigotski 2009, p. 136).

A linguagem interior assemelha-se à linguagem egocêntrica quanto à funcionalidade e a estruturação. A linguagem interior é uma linguagem silenciosa, monológica, compreensível para si mesma, reduzida, que revela a tendência a falhas e à abreviação. (Vigotski 2009, pp. 51, 57-8). Concepções anteriores consideravam a linguagem interior como aquilo que se reproduz na memória, uma simples fala silenciosa ou o que antecede a linguagem exterior. A linguagem interior é mais que tudo isso, "é um processo de transformação do pensamento em palavra,... é um processo de evaporação da linguagem no pensamento" (Vigostski 2009, p. 425). A linguagem interior torna-se interior por sua função cognitiva, ela se desenvolve mediante um lento acúmulo de mudanças estruturais e funcionais. 
A dificuldade do indivíduo em expressar verbalmente o conhecimento aprendido está enraizada nas características da linguagem interior. A explicação de um conceito solicita o uso preciso do significado das palavras, um discurso decomposto. A exteriorização da linguagem interior através da fala é facilitada pela comunicação corporal, pela entonação. A linguagem escrita requer o desenvolvimento máximo do pensamento pela ausência do interlocutor. $O$ discurso escrito é sintaticamente complexo. A enunciação de cada pensamento isolado emprega palavras, expressões e construções que pareceriam contranaturais na linguagem falada (Vigotski 2009, p. 452).

Vigotski elaborou a hipótese da linguagem interior no final da sua vida sem a comprovar. Entre o final do século XX e o ínicio do século XXI, neurocientistas verificaram que a linguagem interior está relacionada com a gramática, a produção de linguagem e funções executivas (processos psicológicos superiores), conforme proposto por Vigotski, através de testes com imagens do cérebro realizadas por tomografia e ressonância magnética (Ardila, 2016).

\subsection{A linguagem escrita}

A palavra escrita é um signo mnmônico que enquanto instrumento cultural, amplia a capacidade humana de registro e comunicação. $\mathrm{Na}$ filogênese, o desenvolvimento da escrita vincula-se ao desenvolvimento da memória. $\mathrm{Na}$ ausência da escrita, o homem iletrado desenvolve uma memória eidética (fotográfica) sensorialmente acurada, necessária para se deslocar pelas áreas naturais, transmitir a informação oral e visualmente. A escrita é um instrumento de domínio da memória. Os registros da linguagem escrita presentes na arte rupestre e nos hieroglifos demonstram a tendência do homem primitivo a "falar com os olhos", a desenhar e pintar o que se quer exprimir. Ele usa uma linguagem pictórica, manifestação da sua memória visual (Vigotski 1996, pp.107, 124).

$\mathrm{Na}$ ontogênese, a escrita nasce do gesto que se transforma na garatuja, no desenho da criança, uma linguagem gráfica que surge da linguagem verbal. No entanto, o desenho de letras, gestos mecânicos, não constitui a linguagem escrita em si, um sistema complexo de signos. Ao contrário da linguagem falada, a linguagem escrita se aprende sistematicamente no contexto escolar (Vigostski 1988, pp. 120,121, 127). A escrita requer alta abstração por ser uma linguagem silenciosa e monológica, ao contrário da fala que se manifesta através do som e de um 
interlocutor físico, aspectos concretos da palavra. Outra diferenciação entre a linguagem falada e a escrita encontra-se na forma de produção. A enunciação da palavra acontece pelo todo, sem a consciência de cada parte componente da palavra. Na escrita, o indivíduo deve ter consciência da estrutura sonora da palavra, desmembrá-la e restaurá-la nos sinais escritos. A estrutura semântica da linguagem escrita também exige trabalho consciente com os significados das palavras e o seu encadeamento lógico. A escrita nasce do diálogo interior com um interlocutor imaginário ou desconhecido, constituindo uma linguagem desenvolvida ao máximo. A linguagem escrita é intencional e consciente. Os signos da linguagem escrita e 0 seu emprego são assimilados pela criança de modo consciente e arbitrário, ao contrário do emprego e assimilação inconscientes de todo o aspecto sonoro da fala. A escrita leva a criança a agir de modo mais intelectual (Vigotski 2009, pp.313, 3168).

\subsection{Desenvolvimento e aprendizagem}

Desenvolvimento e aprendizagem são interdependentes para Vigotski uma vez que os processos cognitivos do indivíduo desenvolvem-se através da aprendizagem mediada por ferramentas psicológicas dentro do contexto sócio cultural. "De um ponto de vista vigotskiniano, a essência da educação cognitiva consiste em prover aos estudantes novas ferramentas psicológicas que podem moldar funções cognitivas gerais ou de domínio específico" (Kozulin 2003, p.16, tradução nossa). As ferramentas psicológicas - signos e símbolos - constituem um aspecto da mediação entre o sujeito e o objeto do conhecimento. Estudos recentes consideram também a mediação através de outro indivíduo ${ }^{29}$ e a mediação na forma de uma atividade de aprendizagem organizada (Kozulin 2003, p.17). O papel do professor é valorizado como agente responsável da atividade de aprendizagem.

\footnotetext{
${ }^{29}$ O papel do mediador humano na aprendizagem parece-nos minimizado na tradução do russo para o português da obra de Vigotski. Bezerra ${ }^{29}$ (2009, p. VIII), explica que a palavra em russo obutchênie pode significar ensinar, ilustrar, adestrar, transmitir algum conhecimento ou habilidade a alguém, disciplinar; ou em outra instância significa ser ensinado, aprender, assimilar conhecimentos, estudar alguma coisa. Ele optou por traduzir como aprendizagem na maioria das vezes e eventualmente como ensino. Segundo Oliveira (2010, p. 56), o melhor significado para obutchênie é processo de ensino-aprendizagem pois Vigotski refere-se a "um processo global de relação interpessoal que envolve, ao mesmo tempo, alguém que aprende, alguém que ensina e a própria relação ensinoaprendizagem."
} 
A imitação consiste numa forma de mediação por um indivíduo. Para Vigotski, a aprendizagem relaciona-se com a capacidade de imitar uma atitude através da zona de desenvolvimento imediato (ZDI), determinada peladiferença entre o nível de desenvolvimento atual e o nível de desenvolvimento potencial. A ZDI a tem mais importância para o processo de aprendizagem e desenvolvimento intelectual do indivíduo (Vigotski 2009, p.329). O desenvolvimento atual do indivíduo corresponde àquilo que ele consegue realizar sozinho com autonomia, indicando 0 amadurecimento de uma função cognitiva. $O$ desenvolvimento potencial do indivíduo corresponde àquilo que ele consegue realizar através da imitação ou com a colaboração de outro indivíduo. A função cognitiva está em estado potencial de desenvolvimento. A zona de desenvolvimento imediato define as funções que estão em processo de maturação, funções que estão em estado embrionário. "Essas funções poderiam ser chamadas de 'brotos' ou 'flores' do desenvolvimento, ao invés de 'frutos' do desenvolvimento" (Vigotski 1988, p.97, aspas do autor). A zona de desenvolvimento imediato determina o campo das transições acessíveis ao indivíduo entre o que ele já sabe e aquilo que pode aprender.

A questão da imitação pode ser entendida como um referencial para aprender algo novo. Para que haja aprendizagem é importante que o professor conduza sua prática pedagógica no sentido de poder ser imitado. $\mathrm{O}$ aluno por meio da imitação, pode construir e interiorizar uma nova estrutura de pensamento (Gaspar 2014,pp.190-1). O aprendizado acontece quando o indivíduo desenvolve sua própria estrutura cognitiva, processo que necessita de um tempo.

O desenvolvimento humano é individual, não linear e heterogêneo. A criança pode aprender e inventar formas culturais de enfrentar problemas em uma área, mas permanecer em níveis anteriores e mais primitivos quando se trata de outras áreas de atividade. Em experimentos com crianças em processo de escolarização, foram detectados traços de pensamento primitivo muitas vezes em crianças bastante desenvolvidas (Luria 2018, p.101). Quando uma criança entra na escola, ela possui suas próprias habilidades culturais desenvolvidas no seu ambiente cultural. A criança não é uma tabula rasa, as atividades e as interações sociais do seu cotidiano, a educação familiar, os intrumentos culturais a que é exposta. "Todavia, quando a criança, com suas perguntas, consegue apoderar-se dos nomes dos objetos que a rodeiam, já está inserida numa etapa específica de aprendizagem" 
(Vigotski 2018, p.110). A aprendizagem deve ser coerente com o nível de desenvolvimento da criança. No ambiente escolar, o material primitivo da criança forjado por suas próprias tentativas será sistematizado em situações de aprendizagem propiciando o desenvolvimento das funções cognitivas superiores, considerando a zona de desenvolvimento imediato e almejando o desenvolvimento potencial da criança. "O único bom ensino é o que se adianta ao desenvolvimento" (Vigotski 2009, p. 114). Em condições apropriadas, processos embrionários no indivíduo de manifestação iminente afloram. É papel do professor incitar nos alunos avanços que não ocorreriam espontaneamente através de de interferência na ZDI (Oliveira 2010, p. 60). Ao mesmo tempo, o professor deve respeitar os limites da ZDI dos alunos para que eles aprendam (Gaspar 2014, p.204).

\subsection{Imaginação e criatividade}

A valorização da imitação no processo de aprendizagem pode dar a ideia de mecanização na educação, formando indivíduos pouco criativos. Na visão de Vigotski, no entanto, a imitação não é o objetivo final do processo de aprendizagem. Uma vez apreendido um conceito ou desenvolvida uma função cognitiva, o indivíduo adquire uma nova percepção da realidade e outras possibilidades de agir. "O cérebro não é apenas o órgão que conserva e reproduz nossa experiência anterior, mas também combina e reelabora, de forma criadora, elementos da experiência anterior, erigindo novas situações e novo comportamento" (Vigotski 2009, p. 14) .

$A$ atividade da imaginação subordina-se à experiência, às necessidades e aos interesses do indivíduo. Ela depende do conhecimento técnico e dos modelos de criação que influenciam a pessoa, portanto vincula-se ao ambiente sócio cultural. Nenhuma invenção ou descoberta científica pode emergir antes que aconteçam as condições materiais e psicológicas necessárias para seu surgimento. A criação é um processo de herança histórica em que cada forma que sucede é determinada pelas anteriores (Vigotski 2009, p. 41-2).

Coerente com o pensamento de Vigotski, a imaginação e a criatividade, a Arte e a Ciência desenvolvem-se de acordo com o ambiente sócio cultural do indivíduo. Por um lado como consequência da vinculação do desenvolvimento das funções cognitivas do indivíduo e o meio cultural, por outro, pelas necessidade e condições impostas por esse meio. 


\subsection{A formação integral - afeto e cognição}

Vigotski concebe um modelo integral de indivíduo. O ser humano é a síntese de um ser biológico e um ser social. A dimensão biológica engloba 0 desenvolvimento filogenético da espécie humana. $\mathrm{Na}$ ontogênese, o indivíduo desenvolve processos naturais de interação com o meio como a visão, a audição etc, e, a influência do amadurecimento das funções biológicas no desenvolvimento das funções cognitivas. A dimensão social considera o processo de adaptação no ambiente natural e cultural, as ferramentas culturais e as interações sociais vinculadas ao desenvolvimento das funções cognitivas superiores.

Essa visão integral refere-se também à constituição do intelecto humano. As funções cognitivas funcionam numa relação interdependente promovendo 0 desenvolvimento integral da consciência. A aquisição de uma forma específica de função cognitiva aumenta as capacidades gerais. No contexto escolar, o docente deve pensar e agir considerando que o indivíduo contém um conjunto de capacidades - observação, atenção, memória, raciocínio - e que o melhoramento de qualquer uma delas reflete no crescimento integral. As funções intelectuais atuam independentemente da disciplina sobre a qual operam, o desenvolvimento de uma dessas faculdades leva necessariamente ao desenvolvimento de outras (Vigotski 2018, p. 107).

A dimensão cognitiva do intelecto está integrada à dimensão afetiva. Pensamento, vontade e afeto integram-se na consciência do indivíduo. O próprio pensamento não nasce de outro pensamento mas do campo da nossa consciência que o motiva, que abrange os nossos pendores e necessidades, os nossos interesses e motivações, os nossos afetos e emoções. Por trás do pensamento existe uma tendência afetiva e volitiva. Só ela pode dar a resposta ao último porquê na análise do pensamento (Vigotski 2009, p. 479).

Da relação afetiva do sujeito com o objeto de conhecimento surge a vontade da mobilização para agir, a motivação (mover+ação). As reações emocionais devem constituir o fundamento do processo educativo. Antes de comunicar algum conhecimento, o professor tem de provocar a correspondente emoção do aluno e se preocupar para que essa emoção esteja ligada ao novo conhecimento. Este só pode se solidificar se tiver passado pelo sentimento do aluno. Um certo grau de sensibilidade emocional, de compromisso, deve servir necessariamente como ponto de partida para qualquer trabalho educativo (Vigotski 2003, p. 121). 
Em última instância, para Vigotski o aspecto afetivo-volitivo impera sobre o cognitivo. As funções elementares se tornam superiores quando são voluntárias. $O$ domínio volitivo implica o controle das funções naturais e reações impulsivas diferenciando o homem do animal. Do ponto de vista vigotskiniano, força de vontade, atenção se desenvolvem através da educação. O sentido da palavra resulta da união afetivo-cognitiva podendo pender mais para um ou outro aspecto.

\subsection{A prática de ensino-aprendizagem}

A atividade de aprendizagem organizada trazida pelos pesquisadores russos pós Vigotski, enfatiza a importância da educação formal. O desenvolvimento do conceito científico e das funções cognitivas superiores ocorrem primordialmente no ambiente da cultura escolar. Estudiosos de Vigostki consideram que não há uma proposta pedagógica sistematizada baseada nas suas pesquisas (Karpov, 2003) (Oliveira, 2010) (Gaspar, 2014).

Karpov (2003, p.68-9) aponta para a combinação do conhecimento conceitual e do conhecimento procedimental no ensino dos conceitos científicos. Por essa abordagem didática, pesquisadores russos constataram que os estudantes apresentaram melhor domínio conceitual, transferência e uso intencional da apredizagem. Eles são capazes de justificar suas respostas, comprovar a resolução de um problema e defender uma opinião ou resultado.

Segundo Gaspar (2014, p.175), uma metodologia vigotskiniana de ensinoaprendizagem se apoia em duas ideias básicas: a aprendizagem como fator determinante do desenvolvimento e a relação entre motivação e pensamento. Ele elege como aspecto fundamental as interações sociais em sala de aula. O professor é o parceiro mais capaz que deve orientar sua conduta considerando (i) os limites da zona de desenvolvimento imediato dos alunos para que eles possam aprender ; (ii) a motivação dos alunos, para que eles queiram aprender; (iii) a imitação de sua conduta pelos alunos, para que eles consigam começar a aprender (Gaspar 2014, pp. 203-4, Itálicos do autor). Além destes aspectos, Gaspar aborda outros pontos relevantes no cotidiano de sala de aula que auxiliam na compreensão de como aplicar as ideias de Vigotski. Apresentaremos estes aspectos a seguir. 


\subsubsection{Tempo de aprendizagem e estudo}

O aluno necessita de tempo para construir suas próprias estruturas para consolidar a aprendizagem. Dentro de seu próprio tempo, o aluno pode desenvolver e interiorizar a nova estrutura cognitiva. Dependendo das estruturas genéticas de pensamento do aluno, a compreensão de um conceito pode levar anos (Gaspar 2014, pp.190-2).

A aprendizagem é individual. $\mathrm{Na}$ sala de aula o ensino é coletivo. Dependendo da zona de desenvolvimento imediato do aluno, a aprendizagem de um conhecimento novo pode mais rápida ou mais lenta.

\subsubsection{Aprender é estudar}

Em sala de aula com o professor, os alunos apenas começam a aprender. $\mathrm{O}$ domínio do conteúdo se dá com o desenvolvimento de uma estrutura cognitiva, o que demanda tempo e esforço dos próprios alunos. As tarefas de casa motivadoras e adequadas para o nível de desenvolvimento do aluno são importantes para que ele trabalhe sozinho com situações para construir novas estruturas de pensamento. "Talvez essa seja a principal estratégia vigotskiniana de aprendizagem, que em nada difere da recomendação de qualquer pessoa de bom senso: para aprender é preciso estudar, estudar, estudar..." (Gaspar 2014, p.205). Subentende-se que o "estudar" implica a orientação do professor que propõe uma atividade organizada de aprendizagem, mediadora do desenvolvimento.

Vigotski enfatiza a influência do ambiente sócio cultural no desenvolvimento do indivíduo. Há fatores que estão além da vontade do indivíduo. As condições sociais do aluno também interferem em suas possibilidades de aprendizagem. A necessidade de ajudar a família trabalhando ou com tarefas domésticas, viver em condições que não favorecem um ambiente adequado para estudar ou mesmo sem condições básicas para o desenvolvimento físico e emocional saudáveis podem afetar o processo de aprendizagem do aluno.

\subsubsection{Definir o conceito no início da sequência de ensino-aprendizagem}

Ensinar conceitos prontos a partir de sua definição não é errado do ponto de vista de Vigotski. "O erro está em acreditar que isso é suficiente para que a aprendizagem aconteça de imediato, ignorando o tempo que se faz necessário para a mente do aluno construir as novas estruturas.[...]" (Gaspar 2014, p.192). Quando 
Vigotski diz "os adultos não podem transmitir à criança o seu modo de pensar", e "[...] a relação entre pensamento e palavra é um processo de vivo de nascimento do pensamento na palavra" (Vigotski 2009, p. 484), entendemos que o engajamento do aluno em atividades propostas pelo professor, atividades que realize mobilizado pela sua motivação e o nível do desenvolvimento do aluno são fatores determinantes do processo de aprendizagem.

\subsubsection{Experimentos científicos}

Há duas grandes vantagens na inserção de atividades experimentais no processo de ensino-aprendizagem: a motivação e a concretização de conceitos físicos.

A motivação gerada pelo impacto de experimentos que possam surpreender, os alunos por contrariar ou superar suas expectativas; que possibilitem previsão e verificação do resultado - para isso é fundamental o professor selecionar experimentos acessíveis para o aluno e que funcionem (Gaspar 2014, pp. 228-9). Consideramos também o fator emocional pelo encantamento, como na decomposição da luz, na formação de sombras coloridas e outros experimentos envolvendo cor.

A concretização de conceitos físicos através da atividade experimental pode compensar "a maior desvantagem cognitiva dos alunos na aquisição de conceitos científicos em relação aos conceitos espontâneos - a dificuldade de 'visualizálos'.[...]" (Gaspar 2014, p. 228-9, aspas do autor). Dependendo de como a atividade experimental é proposta, o aluno pode realizar o percurso do pensamento concreto para o abstrato formando o conceito. A palavra evolui do pensamento visual concreto para o abstrato.

A observação, prática inerente à realização da atividade experimental, possibilita o desenvolvimento da atenção voluntária e da percepção. "A percepção é parte de um sistema dinâmico de comportamento; por isso, a relação entre as transformações dos processos perceptivos $\mathrm{e}$ as transformações em outras atividades intelectuais é de fundamental importância" (Vigotski 1988, p.40). O professor como mediador da aprendizagem pode orientar a observação direcionar o olhar do aluno.

A atividade experimental mediadora da aprendizagem pode ser orientada por questões propostas em roteiros, pois é impossível para o professor acompanhar 
todos os grupos ao mesmo tempo. Numa pedagogia vigotskiniana, o aluno não aprende o conteúdo teórico da experiência com a montagem ou com a realização de medidas ou cálculos, mas com as interações sociais desencadeadas durante a execução da atividade que podem também ser originadas por questões propostas para discussão nesses roteiros (Gaspar 2014, p.227).

O roteiro pressupõe um aluno ativo, agente epistêmico. Deve propor questões que permitam o desenvolvimento cognitivo, e não simplesmente a execução de ações mecânicas.

\subsubsection{Aprendizagem do conceito científico}

A palavra é o grande mediador do pensamento. Nos exemplos concretos ou no desejo de contextualizar com um fenômeno familiar para o aluno, cuidar para não incorrer na formação de pseudoconceitos, como no exemplo do arco-íris abordado anteriormente.

O conceito é aprendido quando se adquire consciência do seu significado. $O$ aluno é capaz de explicar o conceito e aplicá-lo na resolução de problemas. No entanto, a dificuldade em explicar um conceito é intrínseca à própria complexidade da transição da linguagem interna para a linguagem exterior falada ou escrita.

\subsubsection{Tecnologia da informação e comunicação (TIC)}

$\mathrm{Na}$ educação do século XXI, o uso de tecnologia de informação e comunicação é uma questão cada vez mais presente. Enquanto instrumentos de natureza simbólica, estes meios de comunicação e informação são potenciais mediadores das relações entre sujeito e objeto de conhecimento e, portanto, possíveis elementos constitutivos das modalidades de fundamento psicológico dos membros dessas sociedades (Oliveira 2010, p. 80).

O pressuposto básico do desenvolvimento humano na perspectiva de Vigotski consiste na constituição histórica da consciência do indivíduo. Os instrumentos psicológicos se desenvolvem, são adquiridos e transmitidos no seu ambiente cultural. Os processos de aprendizagem, portanto, devem ser dinâmicos adaptandose a cada cultura, a cada momento histórico. 


\section{A SEQUÊNCIA DE ENSINO-APRENDIZAGEM}

\subsection{A construção da sequência de ensino-aprendizagem}

\subsubsection{A abordagem histórico-cultural}

A partir de nossos estudos sobre a abordagem histórico-cultural de desenvolvimento de Vigotski, elaboramos uma sequência de ensino-aprendizagem (SEA) considerando:

(i) a motivação, a emoção como ponto de partida através de experimentos que encantam e despertam a curiosidade, da obra de arte observada ao vivo ou uma obra criativa como desencadeadora de exploração experimental;

(ii) o mediador cultural

a. a linguagem: a abordagem conceitual de conceitos mais gerais para o mais específico - a formação de cor como um caso particular da interação luz-matéria; relacionar os conceitos científicos com 0 conceito cotidiano, cuidando da precisão linguística;

b. o museu de arte e as obras de arte;

c. uso de tecnologias: vídeos ilustrativos sobre conceitos científicos; simuladores virtuais, aplicativos para smartphone; apresentação de slides, desmostrações.

(iii) o mediador humano

a. a professora formadora conduz a aprendizagem dos conceitos científicos, facilita a discussão entre pares; organiza as atividades didáticas; dá assistência aos grupos durante a execução das atividades

b. entre pares ; por atividades em grupo, rodas de conversa com a classe;

C. pela

d. imitação através de exemplos;

(iv) a conjugação dos conhecimentos conceitual e procedimental. Os procedimentos da ciência através de experimentos científicos que possibilitam observação, identificação de variáveis, medição, levantamento e verificação de hipóteses, descrição, análise e conclusão. Os procedimentos de arte através da visitação a museu de arte, observação de imagem, criação de obras explorando diferentes materiais. 


\subsubsection{As competências da Base Nacional Comum Curricular}

Na Base Nacional Comum Curricular (BNCC), competência é definida como a mobilização de conhecimentos (conceitos e procedimentos), habilidades (práticas, cognitivas e socioemocionais), atitudes e valores para resolver demandas complexas da vida cotidiana, do pleno exercício da cidadania do mundo do trabalho (Brasil 2017, p. 8). Consideramos esta definição compatível com a abordagem teórico cultural. Vimos que a aprendizagem do conceito implica em aprendizagem conceitual e procedimental; as ações do indivíduo vinculam-se ao desenvolvimento das funções cognitivas mediadas pelas interações sociais, e as funções cognitivas, afetivas e volitivas integram a consciência do indivíduo.

Das dez competências gerais da BNCC (Brasil 2017, p.9) desenvolvemos aspectos de quatro, cujo texto original apresentamos no quadro 1; na coluna à direita do quadro, relacionamos as atividades em que aplicamos tal compentência.

Quadro 1- Competências gerais da BNCC aplicadas na sequência de ensino-aprendizagem .

\begin{tabular}{|c|c|}
\hline $\begin{array}{l}\text { Competências gerais da base nacional comum curricular } \\
\text { desenvolvidas na sequência de ensino-aprendizagem }\end{array}$ & Como \\
\hline $\begin{array}{l}\text { Exercitar a curiosidade intelectual e recorrer à abordagem } \\
\text { própria das ciências, incluindo a investigação, a reflexão, a } \\
\text { análise crítica, a imaginação e a criatividade, para investigar } \\
\text { causas, elaborar e testar hipóteses, formular e resolver } \\
\text { problemas e criar soluções (inclusive tecnológicas) com base } \\
\text { nos conhecimentos das diferentes áreas. }\end{array}$ & $\begin{array}{l}\text { Experimentos } \\
\text { investigativos; } \\
\text { criação de } \\
\text { visuais. }\end{array}$ \\
\hline $\begin{array}{l}\text { Valorizar e fruir as diversas manifestações artísticas e culturais, } \\
\text { das locais às mundiais, e também participar de práticas } \\
\text { diversificadas da produção artístico-cultural. }\end{array}$ & $\begin{array}{l}\text { Visita ao MASP; } \\
\text { pesquisa de artistas: } \\
\text { Anish Kapoor, Carlos } \\
\text { Cruz-Diez, Julio Le } \\
\text { Parc, Mondrian. }\end{array}$ \\
\hline $\begin{array}{l}\text { Utilizar diferentes linguagens - verbal (oral ou visual-motora, } \\
\text { como Libras, e escrita), corporal, visual, sonora e digital -, bem } \\
\text { como conhecimentos das linguagens artística, matemática e } \\
\text { científica, para se expressar e partilhar informações, } \\
\text { experiências, ideias e sentimentos em diferentes contextos e } \\
\text { produzir sentidos que levem ao entendimento mútuo. }\end{array}$ & $\begin{array}{l}\text { Proposição de } \\
\text { questões dissertativas, } \\
\text { apresentação de } \\
\text { trabalhos; expressão } \\
\text { através de desenhos, } \\
\text { esquemas, produção } \\
\text { de "livro de arte". }\end{array}$ \\
\hline $\begin{array}{l}\text { Compreender, utilizar e criar tecnologias digitais de informação e } \\
\text { comunicação de forma crítica, significativa, reflexiva e ética nas } \\
\text { diversas práticas sociais (incluindo as escolares) para se } \\
\text { comunicar, acessar e disseminar informações, produzir } \\
\text { conhecimentos, resolver problemas e exercer protagonismo e } \\
\text { autoria na vida pessoal e coletiva. }\end{array}$ & $\begin{array}{l}\text { Uso de vídeos } \\
\text { didáticos; aplicativos } \\
\text { para demonstração de } \\
\text { fenômenos físicos. } \\
\text { Uso de aplicativo de } \\
\text { comunicação para } \\
\text { trocar impressões, } \\
\text { informações, } \\
\text { esclarecer dúvidas. }\end{array}$ \\
\hline
\end{tabular}


O conteúdo abordado constitui-se de interação luz-matéria (reflexão, transmissão e aborção), cores primárias, processo aditivo e subtrativo de cores, formação e visão de cores. Procuramos introduzir o mínimo de termos específicos e possibilitar a vivência prática com os conceitos através de atividades artísticas e experimentais. Os recursos tecnológicos (vídeos, aplicativos, simuladores virtuais) majoritariamente foram uitlizamos como ferramentas durante a exposição teórica por limitações dos recursos disponíveis no local do curso. Como produto de narrativa do percurso durante o curso, as professoras produziram um "livro de arte", veículo de livre expressão do aprendizado e de impressões pessoais. A orientação de produção "do livro de arte" encontra-se no apêndice 1.

A seguir apresentamos a SEA aplicada no 17ํ USP-Escola (14.01-18.01.2019), as habilidades da BNCC desenvolvidas e os roteiros das atividades práticas propostas.

As tabelas (tabelas 2 e 3) contém as habilidades propostas encontram-se após o programa do curso. Chamamos a atenção para o ano escolar de desenvolvimento da habilidade da BNCC. Em Ciências, o ano é determinado no currículo e em Artes a mesma habilidade pode ser oferecida em todos os anos daquele nível. Esta flexibilização no currículo de Artes facilita a integração de artes com outras disciplinas. 


\subsection{Curso: Cor - Elo de Integração entre Arte e Ciência}

$$
2^{\text {a }} \text { feira }-14.01
$$

\begin{tabular}{|l|l|l|l|}
\hline Horário & Habilidade & \multicolumn{1}{|c|}{ Conteúdo } & \multicolumn{1}{|c|}{ Atividade } \\
\hline $\begin{array}{l}\text { 11h00 } \\
\text { AULA 1 }\end{array}$ & $\begin{array}{l}\text { Visão geral } \\
\text { Apresentações } \\
\text { O que sabemos } \\
\text { sobre cor? }\end{array}$ & \\
\hline 12h30 & ALMOÇO & $\begin{array}{l}\text { O que sabemos } \\
\text { sobre cor? } \\
\text { (cont.) }\end{array}$ & $\begin{array}{l}\text { Atividade lúdico-experimental - Doces } \\
\text { coloridos }\end{array}$ \\
\hline $\begin{array}{l}\text { 13h30 } \\
\text { AULA 2- }\end{array}$ & $\begin{array}{l}\text { EF09CI04 } \\
\text { EF15AR01 }\end{array}$ \\
\hline 15h00 & PAUSA & $\begin{array}{l}\text { Interação luz- } \\
\text { matéria: } \\
\text { reflexão, } \\
\text { transmissão e } \\
\text { absorção }\end{array}$ & $\begin{array}{l}\text { Atividade artístico-experimental: } \\
\text { Criando com materiais diferentes. } \\
\text { Painel coletivo. }\end{array}$ \\
\hline 17h00 2 & $\begin{array}{l}\text { EF02Cl02 } \\
\text { EF15ARI02 }\end{array}$ & FIM \\
\hline
\end{tabular}

$$
3^{\text {a }} \text { feira }-15.01
$$

\begin{tabular}{|c|c|c|c|}
\hline $\begin{array}{l}\text { 10h00 } \\
\text { AULA } 3\end{array}$ & $\begin{array}{l}\text { EF15AR01 } \\
\text { EF69AR04 }\end{array}$ & $\begin{array}{l}\text { MASP } \\
\text { Visita ao acervo } \\
\text { permanente. }\end{array}$ & \\
\hline $12 \mathrm{~h} 30$ & \multicolumn{3}{|l|}{ ALMOÇO } \\
\hline $\begin{array}{l}\text { 14h30 } \\
\text { AULA } 4\end{array}$ & $\begin{array}{l}\text { (EF03CI02) } \\
\text { (EF02CI08) }\end{array}$ & $\begin{array}{l}\text { Roda de } \\
\text { conversa sobre a } \\
\text { visita ao MASP. } \\
\text { Revisão: } \\
\text { absorção e } \\
\text { reflexão. } \\
\text { Percepção da luz } \\
\text { refletida. } \\
\text { Cor fria e cor } \\
\text { quente. }\end{array}$ & $\begin{array}{l}\text { Atividades experimentaos: } \\
\text { Percepção da luz refletida - aplicativo: } \\
\text { Medidor de luz. } \\
\text { Demonstração: } \\
\text { Refletividade do branco e do preto } \\
\text { Cor fria e cor quente. } \\
\text { Determinação da temperatura de soluções } \\
\text { coloridas. }\end{array}$ \\
\hline $17 \mathrm{~h} 00$ & \multicolumn{3}{|r|}{ e } \\
\hline
\end{tabular}


$4^{a}$ feira -16.01

\begin{tabular}{|c|c|c|c|}
\hline $\begin{array}{l}\text { 10h00 } \\
\text { AULA } 5\end{array}$ & $\begin{array}{l}\text { EF02Cl08 } \\
\text { EF09CI04 }\end{array}$ & $\begin{array}{l}\text { Revisão: } \\
\text { absorção e } \\
\text { reflexão. } \\
\text { Aquecimento } \\
\text { global. } \\
\text { Modelos de luz. A } \\
\text { luz como onda. } \\
\text { Frequência, } \\
\text { comprimento de } \\
\text { onda, amplitude e } \\
\text { velocidade de } \\
\text { onda. } \\
\text { Espectro } \\
\text { eletromagnético. } \\
\\
\text { Decomposição da } \\
\text { luz branca. } \\
\text { Interação luz } \\
\text { matéria: refração } \\
\text { e difração . } \\
\text { Prisma. }\end{array}$ & $\begin{array}{l}\text { Vídeo: This World Is Black and White - } \\
\text { NASA } \\
\text { Disponível em } \\
\text { https://youtu.be/sCxlqgZA7ag (Acesso em } \\
15.01 .2019) \\
\text { Demonstração: } \\
\text { Onda com a mola slinky } \\
\text { Vídeo: - Science. Nasa - The } \\
\text { eletromagnetic spectrum } \\
\text { https://youtu.be/cfXzwh3KadE } \\
\text { Simuladores virtuais: } \\
\text { Refração da luz em uma lâmina de faces } \\
\text { paralelas. } \\
\text { Disponível em } \\
\text { https://micro.magnet.fsu.edu/primer/java/science } \\
\text { opticsu/refraction/index.html [acesso em } \\
15.01 .2019] . \\
\text { Decomposição e recomposição da luz solar. } \\
\text { Disponível em } \\
\text { https://micro.magnet.fsu.edu/primer/java/science } \\
\text { opticsu/newton/index.html [acesso em } \\
15.12 .2019] . \\
\text { Atividade experimental: } \\
\text { Observacão do espetro da luz com prisma. }\end{array}$ \\
\hline $12 \mathrm{~h} 30$ & ALMOÇO & & \\
\hline $\begin{array}{l}\text { 13h30 } \\
\text { AULA } 6\end{array}$ & $\begin{array}{l}\text { EF09CI04 } \\
\text { EF15AR04 } \\
\text { EF15AR05 }\end{array}$ & $\begin{array}{l}\text { Decomposição da } \\
\text { luz } \\
\text { Espectroscópio. }\end{array}$ & $\begin{array}{l}\text { Atividade experimental: } \\
\text { Construção de espectroscópio. Observação } \\
\text { do espectro da luz. } \\
\text { Atividade artística: } \\
\text { Criando com cores espectrais - painel } \\
\text { coletivo } \\
\text { Pesquisar as obras de Júlio Le Parc }\end{array}$ \\
\hline $15 \mathrm{~h} 00$ & PAUSA & & \\
\hline $\begin{array}{l}\text { 15h20 } \\
\text { AULA } 6\end{array}$ & $\begin{array}{l}\text { EF06Cl08 } \\
\text { EF09CI04 }\end{array}$ & $\begin{array}{l}\text { Modelo } \\
\text { tricromático de } \\
\text { visão de cores. } \\
\text { As cores } \\
\text { primárias e } \\
\text { complementares } \\
\text { da luz. } \\
\text { Mistura aditiva. }\end{array}$ & $\begin{array}{l}\text { Aplicativos: Visão de cor } \\
\text { https://phet.colorado.edu/sims/html/color- } \\
\text { vision/latest/color-vision pt BR.html } \\
\text { RGB e Color lab. } \\
\text { Visita: Laboratório de Demonstrações } \\
\text { Ernest Hamburger } \\
\text { Mistura aditiva e subtrativa com luzes. } \\
\text { Sombras coloridas. Teatro de sombras } \\
\text { coloridas. Bolhas de sabão gigantes. } \\
\text { Holografia. }\end{array}$ \\
\hline $17 \mathrm{~h} 00$ & \multicolumn{3}{|r|}{ 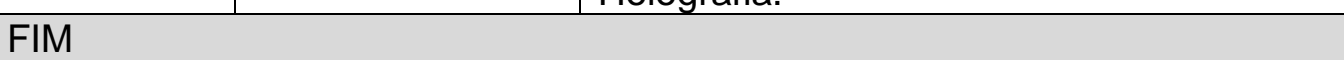 } \\
\hline
\end{tabular}


$5^{\mathrm{a}}$ feira -17.01

\begin{tabular}{|c|c|c|c|}
\hline $\begin{array}{l}10 \mathrm{~h} 00 \\
\text { AULA } 7\end{array}$ & $\begin{array}{l}\text { EF09CI04 } \\
\text { EF15AR04 } \\
\text { EF69AR05 }\end{array}$ & $\begin{array}{l}\text { Mistura aditiva } \\
\text { pelos discos } \\
\text { rotativos. } \\
\text { Matiz, saturação } \\
\text { e brilho } \\
\text { Cores primárias } \\
\text { da impressora e } \\
\text { das pinturas. } \\
\text { Mistura } \\
\text { subtrativa }\end{array}$ & $\begin{array}{l}\text { Atividade experimental: } \\
\text { Discos rotativos de cor - disco de Newton } \\
\text { Aplicativos: Color lab formação de cor no } \\
\text { Windows. } \\
\text { Cores primárias nas telas (smartphone, monitor } \\
\text { etc) } \\
\text { Pesquisar as obras de Mondrian, Carlos Cruz- } \\
\text { Diez } \\
\text { Experimento-arte. } \\
\text { Mistura subtrativa. Pintura a dedo. }\end{array}$ \\
\hline $12 \mathrm{~h} 30$ & \multicolumn{3}{|l|}{ ALMOÇO } \\
\hline $\begin{array}{l}13 \mathrm{~h} 30 \\
\text { AULA } 8\end{array}$ & $\begin{array}{l}\text { EF09CI04 } \\
\text { EF15AR02 } \\
\text { EF15AR04 } \\
\text { EF69AR05 }\end{array}$ & $\begin{array}{l}\text { Mistura } \\
\text { subtrativa }\end{array}$ & $\begin{array}{l}\text { Atividade artístico-experimental: } \\
\text { Construir círculo cromático : investigação com } \\
\text { materiais diferentes: } \\
\text { lápis de cor. }\end{array}$ \\
\hline $15 \mathrm{~h} 00$ & \multicolumn{3}{|l|}{ PAUSA } \\
\hline $\begin{array}{l}\text { 15h20 } \\
\text { AULA } 8\end{array}$ & $\begin{array}{l}\text { EF15AR02 } \\
\text { EF15AR04 } \\
\text { EF69AR05 }\end{array}$ & $\begin{array}{l}\text { Mistura } \\
\text { subtrativa }\end{array}$ & $\begin{array}{l}\text { Atividade artístico-experimental: } \\
\text { investigação com materiais diferentes: tinta } \\
\text { caseira e tinta de impressora jato de tinta }\end{array}$ \\
\hline $17 \mathrm{~h} 00$ & \multicolumn{3}{|r|}{ e } \\
\hline
\end{tabular}

\begin{tabular}{|c|c|c|c|}
\hline \multicolumn{4}{|c|}{6 feira -18.01} \\
\hline $\begin{array}{l}\text { 10h00 } \\
\text { AULA } 7\end{array}$ & $\begin{array}{l}\text { EF03CI02 } \\
\text { EF09CI04 } \\
\text { EF15AR04 } \\
\text { EF69AR05 }\end{array}$ & $\begin{array}{l}\text { Filtros de luz. } \\
\text { Transmissão da } \\
\text { luz. } \\
\text { Trabalho com o } \\
\text { "Livro de arte" }\end{array}$ & $\begin{array}{l}\text { Atividade artístico-experimental: } \\
\text { Observação de imagens artísticas com filtros de } \\
\text { luz. } \\
\text { Criação de obras com filtros de luz. }\end{array}$ \\
\hline $12 \mathrm{~h} 30$ & \multicolumn{3}{|l|}{ ALMOÇO } \\
\hline $\begin{array}{l}13 \mathrm{~h} 30 \\
\text { AULA } 8\end{array}$ & & $\begin{array}{l}\text { Finalização e } \\
\text { exposição do } \\
\text { Livro de Arte }\end{array}$ & \\
\hline $15 \mathrm{~h} 00$ & \multicolumn{3}{|l|}{ PAUSA } \\
\hline 15h20 & & $\begin{array}{l}\text { Avaliação pós } \\
\text { curso. }\end{array}$ & \\
\hline $17 \mathrm{~h} 00$ & \multicolumn{3}{|l|}{ FIM } \\
\hline
\end{tabular}


Tabela 2 - Habilidades de Ciências do ensino fundamental abordadas na SEA [destaques em negrito nosso].

\begin{tabular}{|c|c|c|c|}
\hline ANO/FAIXA & $\begin{array}{l}\text { UNIDADES } \\
\text { TEMÁTICAS }\end{array}$ & $\begin{array}{l}\text { OBJETOS DE } \\
\text { CONHECIMENTO }\end{array}$ & HABILIDADES \\
\hline $2^{0}$ & $\begin{array}{ll}\text { Matéria } & \mathrm{e} \\
\text { energia } & \end{array}$ & $\begin{array}{l}\text { Propriedades e } \\
\text { usos dos materiais } \\
\text { Prevenção de } \\
\text { acidentes } \\
\text { domésticos }\end{array}$ & $\begin{array}{l}\text { (EF02CI02) Propor o uso de } \\
\text { diferentes materiais para a } \\
\text { construção de objetos de uso } \\
\text { cotidiano, tendo em vista algumas } \\
\text { propriedades desses materiais } \\
\text { (flexibilidade, } \\
\text { transparência etc.). }\end{array}$ \\
\hline $2^{0}$ & $\begin{array}{l}\text { Terra } \\
\text { Universo }\end{array}$ & $\begin{array}{l}\text { Movimento } \\
\text { aparente do Sol no } \\
\text { céu } \\
\text { O Sol como fonte } \\
\text { de luz e calor }\end{array}$ & $\begin{array}{l}\text { (EF02CI08) Comparar o efeito da } \\
\text { radiação solar (aquecimento e } \\
\text { reflexão) em diferentes tipos de } \\
\text { superfície (água, areia, solo, } \\
\text { superfícies escura, clara e } \\
\text { metálica etc.). }\end{array}$ \\
\hline $3^{\circ}$ & $\begin{array}{l}\text { Matéria } \\
\text { energia }\end{array}$ & $\begin{array}{l}\text { Produção de som } \\
\text { Efeitos da luz nos } \\
\text { materiais } \\
\text { Saúde auditiva e } \\
\text { visual }\end{array}$ & $\begin{array}{l}\text { (EF03CI02) Experimentar e relatar } \\
\text { o que ocorre com a passagem da } \\
\text { luz através de objetos } \\
\text { transparentes (copos, janelas de } \\
\text { vidro, lentes, prismas, água etc.), } \\
\text { no contato com superfícies polidas } \\
\text { (espelhos) e na intersecção com } \\
\text { objetos opacos (paredes, pratos, } \\
\text { pessoas e outros objetos de uso } \\
\text { cotidiano). }\end{array}$ \\
\hline $6^{\circ}$ & Vida e evolução & $\begin{array}{l}\text { Célula como } \\
\text { unidade da vida } \\
\text { Interação entre os } \\
\text { sistemas locomotor } \\
\text { e nervoso } \\
\text { Lentes corretivas }\end{array}$ & $\begin{array}{l}\text { (EF06CI08) Explicar a importância } \\
\text { da visão (captação e interpretação } \\
\text { das imagens) na interação do } \\
\text { organismo com o meio e, com } \\
\text { base no funcionamento do olho } \\
\text { humano, selecionar lentes } \\
\text { adequadas para a correção de } \\
\text { diferentes defeitos da visão. }\end{array}$ \\
\hline 90 & $\begin{array}{l}\text { Matéria } \\
\text { energia }\end{array}$ & $\begin{array}{l}\text { Aspectos } \\
\text { quantitativos das } \\
\text { transformações } \\
\text { químicas. Estrutura } \\
\text { da } \\
\text { Radiações e ruas } \\
\text { aplicações rua. } \\
\text { saúde }\end{array}$ & $\begin{array}{l}\text { (EF09CI04) Planejar e executar } \\
\text { experimentos que evidenciem que } \\
\text { todas as cores de luz podem ser } \\
\text { formadas pela composição das } \\
\text { três cores primárias da luz e que } \\
\text { a cor de um objeto está } \\
\text { relacionada também à cor da luz } \\
\text { que o ilumina. }\end{array}$ \\
\hline
\end{tabular}

Disponível em http://basenacionalcomum.mec.gov.br/abase/\#fundamental/arte-no-ensinofundamental-anos-iniciais-unidades-tematicas-objetos-de-conhecimento-e-habilidades [acesso em 19.06.2018]. 
Tabela 3 - Habilidades de Artes Visuais do ensino fundamental abordadas na SEA [destaques em negrito nosso].

\begin{tabular}{|c|c|c|c|}
\hline ANO/FAIXA & $\begin{array}{l}\text { UNIDADES } \\
\text { TEMÁTICAS }\end{array}$ & $\begin{array}{c}\text { OBJETOS DE } \\
\text { CONHECIMENTO }\end{array}$ & HABILIDADES \\
\hline $\begin{array}{l}\text { 10; } 2^{\circ} ; 3^{\circ} ; 4^{\circ} ; \\
5^{\circ}\end{array}$ & Artes visuais & $\begin{array}{l}\text { Contextos } \quad \mathrm{e} \\
\text { práticas }\end{array}$ & $\begin{array}{l}\text { (EF15AR01) Identificar e apreciar } \\
\text { formas distintas das artes visuais } \\
\text { tradicionais e contemporâneas, } \\
\text { cultivando a percepção, o } \\
\text { imaginário, a capacidade de } \\
\text { simbolizar e o repertório imagético. }\end{array}$ \\
\hline $\begin{array}{l}\text { 10; } 2^{\circ} ; 3^{\circ} ; 4^{\circ} ; \\
5^{\circ}\end{array}$ & Artes visuais & $\begin{array}{l}\text { Elementos } \\
\text { linguagem }\end{array}$ & 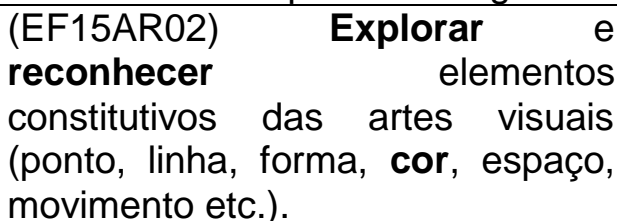 \\
\hline 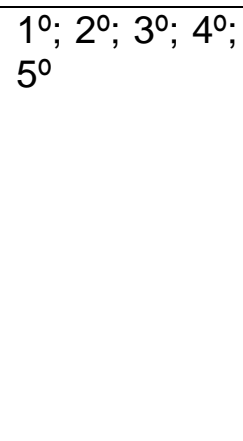 & Artes visuais & Materialidades & $\begin{array}{l}\text { (EF15AR04) } \\
\text { Experimentar } \\
\text { diferentes formas de expressão } \\
\text { artística (desenho, pintura, } \\
\text { colagem, quadrinhos, dobradura, } \\
\text { escultura, modelagem, instalação, } \\
\text { vídeo, fotografia etc.), fazendo uso } \\
\text { sustentável de materiais, } \\
\text { instrumentos, recursos e técnicas } \\
\text { convencionais e nais } \\
\text { convencionais. }\end{array}$ \\
\hline $6^{\circ} ; 7^{0} ; 8^{\circ} ; 9^{\circ}$ & Artes visuais & Materialidades & 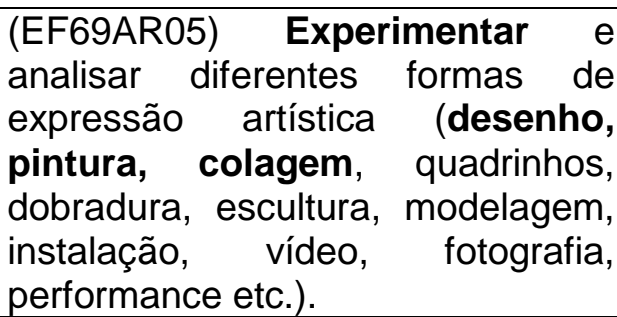 \\
\hline
\end{tabular}

Disponível em http://basenacionalcomum.mec.gov.br/abase/\#fundamental/arte-no-ensino-

fundamental-anos-finais-unidades-tematicas-objetos-de-conhecimento-e-habilidades [acesso em 19.06.2018]. 


\subsection{Roteiro das atividades ${ }^{30}$}

\section{1) Doces coloridos ${ }^{31}$}

Objetivo: problematizar ludicamente a relação entre a percepção da cor de um objeto, a luz incidente e o material da superfície refletora.

Material: doces com cores e texturas diversas como pastilhas de chocolate com cobertura colorida, tipo M\&M (superfície lisa e opaca) ; gelatina Minhoca , tipo Fini (material semi-transparente) ; amendoim colorido; ovinho branco (amendoim japonês com cobertura opaca e esbranquiçada). Bandejas para dispor as guloseimas; luminárias com lâmpadas de LED vermelho, azul; verde; luz branca Obs: lâmpada fulorescente colorida também funciona; a lâmpada de filamento colorida tem um custo menor mas o resultado não é bom.

\section{Orientação:}

Dispor os doces de mesmo tipo na bandeja. Iluminá-los com luz monocromática, uma de cada vez. Observar os doces. Em grupo *, responder:

1.1. Quantas e quais cores você observa com cada luz?

Anotar o resultado de cada grupo no quadro e discutir as razões das diferenças dos valores. Então, responder às questões 2 e 3.

\subsection{Como vemos/percebemos as cores?}

1.3. Qual(is) a(s) dificuldade(s) vocês encontraram para contar a quantidade de cores nos docinhos coloridos? Justifique sua reposta.

*Nota: a atividade em grupo permite aflorar a subjetividade da percepção das cores.

\footnotetext{
${ }^{30} \mathrm{O}$ texto dos roteiros visam o estudante do ensino fundamental.

${ }^{31}$ Vieyra, R., and Hall, C. (2016). Candy Science: Color and Reflection [acesso em 11.04.2018]. Disponível https://www.compadre.org/Repository/document/ServeFile.cfm?|D=14334\&DoclD=4696 


\section{2) Explorando materiais}

Objetivos: criar um painel artístico utilizando materiais de papelaria com propriedades físicas de transparência, opacidade e brilho divesificadas. Explorar, observar e identificar os fenômenos de reflexão, transmissão e absorção da luz.

Material: papéis e materiais de diferentes tipos e cores como papel color set, celofane, lâmina semiespelhada, papelão, espuma vinílica acetinada (E.V.A.), embalagens etc; cola; papel de base do painel (usamos folha de Flip Chart).

Orientação:

2.1. Em grupo, crie um painel com materiais de propriedades físicas variadas, explorando as diferentes formas de interação luz-matéria.

Cada grupo apresenta sua obra, expondo as ideias de concepção. Ao final, os grupos respondem à questão 2.2 .

2.2. O que você pode dizer sobre o comportamento da luz nos diferentes tipos de materiais? Onde a luz é refletida, transmitida e/ou absorvida? 


\section{3) Luminosidade de superfícies coloridas}

Objetivos: propiciar situação para discutir sobre a subjetividade e a objetividade na observação da reflexão da luz. Efetuar medidas de iluminância; utilizar tecnologia aplicativo luxímetro.

Material: papel color set branco, preto, vermelho, azul turquesa, amarelo, verde. Aplicativo: luxímetro O2 LED ILLUMINATION, para Android [download da Playstore em 18.11.2018] ou similar.

\section{Orientação}

3.1. Explore o funcionamento do luxímetro. Quais os parâmetros que você deve considerar para obter bons dados?

3.2. Dispor as folhas de papel sobre o chão, cuidando para que todas incida a mesma intensidade de luz sobre elas.

Antes de medir, que cor você acha que reflete mais luz? Explique sua hipótese.

3.3. Em cada folha de papel, realize a medida da luz refletida com o luxímetro pelo menos cinco vezes. Determine o valor médio e discuta os resultados na próxima questão.

3.4. O valor medido corresponde à sua hipótese? Justifique. 


\section{4) Espectro da luz}

Objetivos: observar o espectro da luz branca por refração e por difração; identificar as componentes do espectro da luz branca, as cores espectrais. Construir um espectroscópio.

Material: prisma, 1 caixa de creme dental, de barrinhas de cereais ou similar; 1 pedaço de $\mathrm{CD}$ descascado ${ }^{32}$ (cerca de $1 \mathrm{~cm} \times 2 \mathrm{~cm}$ ); fita isolante preta.

Construção do espectroscópio

O espectroscópio é um instrumento utilizado para observar o espectro da luz. O espectroscópio de caixinha ${ }^{33}$ utiliza um pedaço de CD como rede difração.

- Num dos lados abertos da caixa, faça uma fenda estreita, menor que $1 \mathrm{~mm}$, utilizando a fita isolante.

- Descubra qual a posição correta do pedaço de CD. Observe a luz através do $C D$ posicionado longitudinal ou transversalmente em relação à caixa. $A$ melhor posição mostra um espectro com faixas nítidas de luzes coloridas.

- Cole o pedaço de CD descascado com a fita isolante.

- Aponte a fenda para a luz. Observe o espectro da luz pelo CD.

Questões:

4.1. ANTES DE REALIZAR A OBSERVAÇÃO, responda quais e quantas cores você espera observar através do prisma? E do espectroscópio?

4.2. O que observou?

4.3. Seus resultados foram semelhantes ou iguais ao que esperava? Como você explica as diferenças caso elas existam?

\footnotetext{
${ }^{32}$ Para remover a película brilhante do CD, quebre-o em pedaços, cole um pedaço de fita crepe na película espelhada, e a puxe rápidamente.

${ }^{33}$ SÃO PAULO. Secretaria Estadual da Educação. Construindo um espectroscópio, p.68. Ciências. Ensino fundamental - anos finais. 8a série/9o ano. Volume 2. Caderno do professor. Material de apoio ao currículo do estado de São Paulo, 2014-2017.
} 


\section{5) Disco rotativo de cores}

Objetivo: efetuar a mistura aditiva de cores através do disco rotativo de cores (comumente denominado "disco de Newton"); dividir um círculo em partes iguais, elaborar e testar hipóteses; observar; identificar variáveis; desenvolver atenção, percepção; descrever.

Material: papel Canson ou similar ; compasso; transferidor; caixa de lápis de cor ou giz de cera com 12 cores; alfinete de mapa.

Construção do disco rotativo de cores

- Construa um círculo de cerca de 6,0 cm de diâmetro.

- Divida-o em sete partes.

- Pinte cada parte com as cores sete cores convencionais do espectro da luz violeta, anil, azul, verde, amarelo, alaranjado e vermelho.

- Prenda o alfinete de mapa no centro. Caso necessite, ajuste com um pedaço de fita crepe.

- Opcional: misturador de líquidos à pilha ou elétrico, furadeira podem ser adaptados para girar o disco produzindo um efeito visual melhor por causa da velocidade de rotação maior e constante.

\section{Questões}

5.1. Antes de realizar o experimento, que cor você espera observar?

\subsection{O que observou?}

5.3. Seus resultados foram semelhantes ou iguais ao que esperava? Como você explica as diferenças caso elas existam?

5.4. 0 que pode fazer para se aproximar do resultado esperado? Realize seus testes e relate o que aconteceu: sua previsão, o que fez e o resultado.

5.5. Desafio: faça um disco rotativo com o mínimo de cores a fim de visualizar a cor branca quando ele girar. Realize seus testes e relate o que aconteceu: sua previsão, o que fez e o resultado. 


\section{6) Mistura subtrativa com lápis de cor}

Objetivos: construir um círculo cromático utilizando três lápis de cor correspondentes às cores primárias de pigmento (ciano, magenta e amarelo). Formar as cores secundárias, terciárias outras pelo processo subtrativo utilizando lápis de cor; observar; desenvolver atenção, percepção; avaliar o efeito da quantidade de cores misturadas; concluir; aplicar os conceitos de reflexão e absorção.

Material: lápis de cor nas cores amarelo, magenta e ciano (nas marcas disponíveis no mercado, o ciano equivale a azul turquesa, o magenta pode ser rosa escuro ou dependendo da marca, o lápis vermelho) ; papel sulfite; régua; transferidor; compasso.

\section{Orientação}

6.1. Testes os pigmentos do seu jogo de lápis de cor, verificando quais são os melhores representantes das cores-pigmento primárias: amarelo, ciano e magenta.

6.2. Desenhe três círculos entrelaçados (diagrama de Venn). Efetue a mistura de cores subtrativas pintando os lápis das cores primárias.

6.3. Quais as cores obtidas a partir das misturas das cores primárias?

6.4. Qual a cor obtida a partir da mistura das três cores? Era o resultado esperado? Explique a diferença, caso houver e o que você poderia fazer para o resultado obtido se aproximar do resultado desejado.

6.5. Explique como acontece o processo subtrativo de formação de cores. Você pode fazer desenhos para ilustrar suas ideias.

6.6. Utilizando três lápis de cor nas cores amarelo, ciano e magenta construa um círculo cromático de 12 partes com as cores primárias, secundárias e terciárias.

6.7. O que você conclui sobre a mistura das cores a partir desta atividade? 


\section{7) Mistura subtrativa com tintas de impressora jato de tinta e/ou tinta caseira com corante alimentício}

Objetivo: perceber a influência do pigmento na formação de cores a partir da formação de cores secundárias e outras pelo processo subtrativo utilizando tintas com diferentes pigmentos; observar; desenvolver atenção, percepção; concluir; criar; descrever, registrar.

Material: tinta para impressora jato de tinta nas cores amarelo, ciano, magenta e preto; tinta caseira (receita após a "orientação"); papel Canson.

\section{Orientação}

(Registre detalhadamente suas investigações.)

7.1. A tinta é produzida basicamente misturando pigmentos com um aglutinante.

Produza suas tintas primárias e teste-as. Qual a cor resultante da mistura das cores-pigmento primárias?

7.2. Você consegue fazer a cor preta?

\subsection{Situação problema}

Você precisa produzir uma obra de arte colorida com custo mínimo, deixando registrado para posterior restauração um registro do processo de fabricação das tintas e da sua palheta de cores. Você recebeu apenas de pigmentos das três cores primárias (magenta, amarelo e ciano) e o aglutinante. Utilizando as cores primárias produzidas, crie uma palheta de cores e a partir dela produza uma pintura.

\section{Tinta caseira}

Material: 1 xícara de chá de farinha de trigo; 2 xícaras de água fervente; 2 xícaras de água fria. Corante alimentício (usamos o corante líquido Mix Coralim - 1 embalagem de $10 \mathrm{~mL}$ nas cores Amarelo Damasco, Rosa Cereja e Azul Anis para ter as cores primárias de pigmento - amarelo, magenta e ciano.)

Procedimento: Coloque duas xícaras de água para ferver. Enquanto isso dissolva a farinha de trigo, preferencialmente peneirada, pouco a pouco na água fria. Quando a água ferver, retire-a do fogo e pouco a pouco adicione a pasta de farinha de trigo 
gradualmente, mexendo sempre para formar uma massa homogênea. Coloque a panela novamente no fogo e deixe ferver durante cerca de 1 minuto. Se necessário deixe evaporar a água ou acrescente mais água até obter uma massa pastosa mais densa. Retire e divida a mistura em diferentes potes (um para cada cor de tinta). Adicione o corante alimentício na cor desejada. A quantidade de corante irá depender da saturação da cor que você deseja para sua tinta. Deixe esfriar para usar. Guarde a tinta na geladeira para conservar melhor. Pode ser usada para pintura a dedo. 


\section{METODOLOGIA DE PESQUISA}

Nossa pesquisa visa a validação de uma sequência de ensino-aprendizagem (SEA) de conteúdos de física da cor na disciplina de Arte para o ensino fundamental.

Delineamos uma pesquisa qualitativa utilizando alguns dados nos moldes de um estudo de caso (Moreira 2011). Os dados foram coletados de questionários pré e pós-curso com questões objetivas e dissertativas; questões propostas nas atividades experimentais; "livro de arte". A análise dos dados para avaliação da aprendizagem conceitual foi baseada em contagem de palavras-chave no início e no final do curso de todas professoras (Pereira 2004, p.34) ; avaliação do uso correto destas palavras por inferência nas representações produzidas no livro de arte e nas respostas das questões dissertativas abertas. A aprendizagem epistêmica foi avaliada através da análise qualitativa das respostas dos roteiros de experiências e da aprensentação de trabalhos.

A avaliação pré e pós-curso foi adaptada de um teste elaborado e aplicado por Teixeira (2007) em alunos do 3 a ano do ensino médio e na questão aplicada por Brito (2015) em alunos do 9ªno ensino fundamental. Validamos esta avaliação com monitores do grupo Arte e Ciência, alunos da graduação de licenciatura e bacherelado em Física do Instituto de Física da USP e um pesquisador sênior do grupo. Os questionários estão no apêndice 2.

Referenciamos a elaboração das propostas experimentais e da SEA num workshop validado de formação de professores Operation Primary Physical Science: Light and Color da Louisiana State University (Kirwin 2000), baseado numa abordagem de ensino investigativo. Testamos e adequamos os experimentos propostos aplicando-os em oficinas com um grupo de cerca de 40 alunos do ensino médio do programa Vivendo USP. Realizamos uma pré-avaliação da SEA que descrevemos a seguir.

Pré-avaliação da sequência de ensino aprendizagem:

Local: curso intensivo de formação continuada docente no 15 USP-Escola.

Perfil: onze docentes da educação básica - Arte, Física, Ciências, Língua Portuguesa e Matemática.

A avaliação da efetividade da sequência de ensino aprendizagem deu-se através de relatos livres ao final do dia sobre o que aprendeu e/ou o que the 
foi mais impactante; observação participante; entrevista com professora de Arte que aplicou a sequência no ensino médio; observação de oficina e comunicação oral (ver anexo 1 ) relativos à sequência de ensinoaprendizagem sobre cor oferecida por essa professora no encontro da Associação dos Professores da Escola Pública, de 16 a 20 julho de 2018, evento paralelo ao $16^{\circ}$ USP-Escola, no Instituto de Física da USP, em São Paulo.

Esta pré-avaliação nos indicou a possibilidade do ensino-aprendizagem de Física na disciplina de Arte. E para isso, a necessidade de simplificar o conteúdo de física e privilegiar atividades experimentais e artísticas. A professora de Arte não desenvolveu nenhuma atividade artística após aplicar a SEA de física da cor, como esperávamos num curso de Arte. Segundo Vigotski a imitação é uma etapa da aprendizagem, conjecturamos que a ausência de exemplo de como integrar arte e ciência justifique as escolhas da professora. Outro indicativo deste ensaio experimental para a coleta de dados foi a necessidade de questões diretivas que possibiltassem a avaliação da aprendizagem.

A coleta efetiva de dados ocorreu no curso intensivo de formação docente continuada oferecido no $17^{\circ}$ USP-Escola, de 14 a 18 de janeiro de 2019, no Instituto de Física da Universidade de São Paulo, em São Paulo. A duração do curso foi de 30 horas de aulas. No total, participaram 24 professoras e professores majoritariamente da rede pública estadual e municipal. O curso contou com uma professora-formadora, dois monitores de física e um monitor de arte para a visita ao MASP. 


\section{ANÁLISE DE DADOS}

\subsection{Visão geral}

A formação inicial das 24 professoras cursantes pode ser visualizada no gráfico 1. Analisamos o material das professoras que desenvolvem atividades de artes visuais - professoras de Artes, Polivalentes e de Educação Infantil. Consideramos para análise o material coletado de 18 cursantes (75\%) do total.

Gráfico 1 - Formação inicial das professoras cursantes. Destacamos em tons de azul o grupo pesquisado.

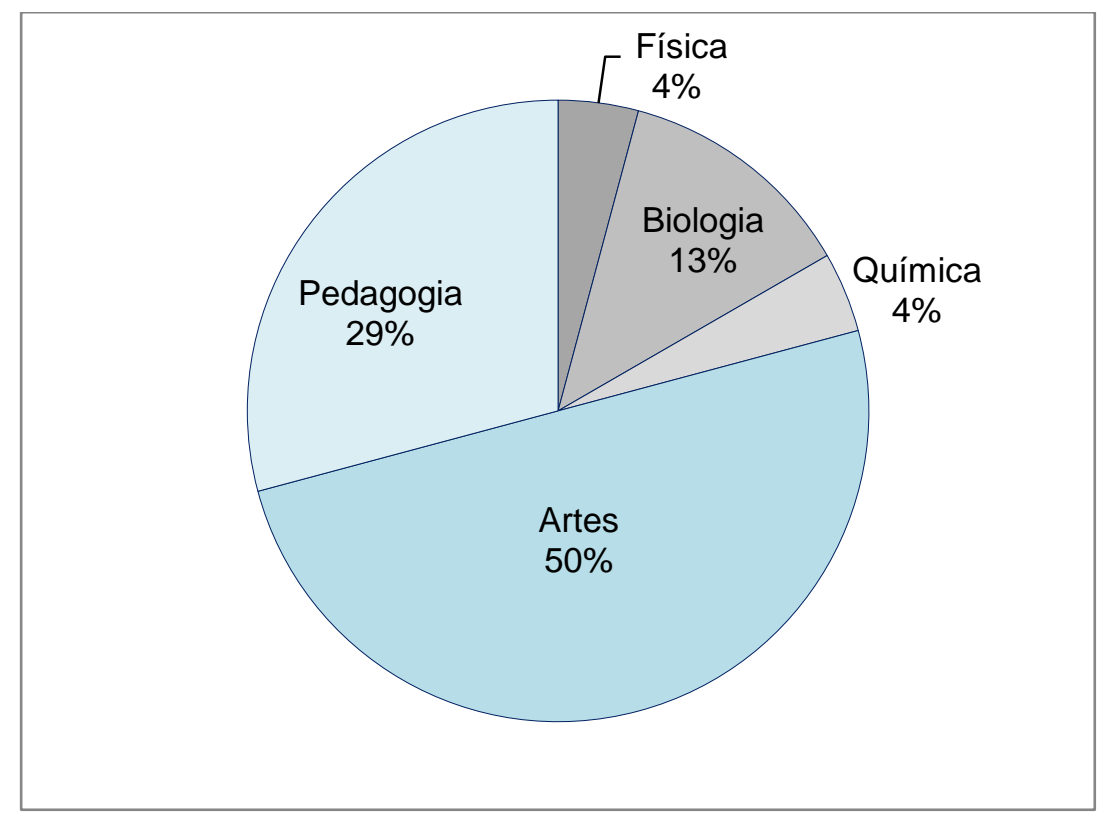

\begin{tabular}{|c|c|}
\hline Pesquisados & $\mathbf{1 8}$ \\
& $\mathbf{7 5 \%}$ \\
\hline Cursantes & 24 \\
\hline
\end{tabular}

\subsection{Avaliação pré e pós-curso}

\subsubsection{Teste geral}

O teste aplicado encontra-se no apêndice 2.

O resultado dos testes pré e pós-curso pode ser visualizado no gráfico 2 . E os acertos por questão no gráfico 3 . 
Gráfico 2 - Total de acertos do teste pré e pós-curso.

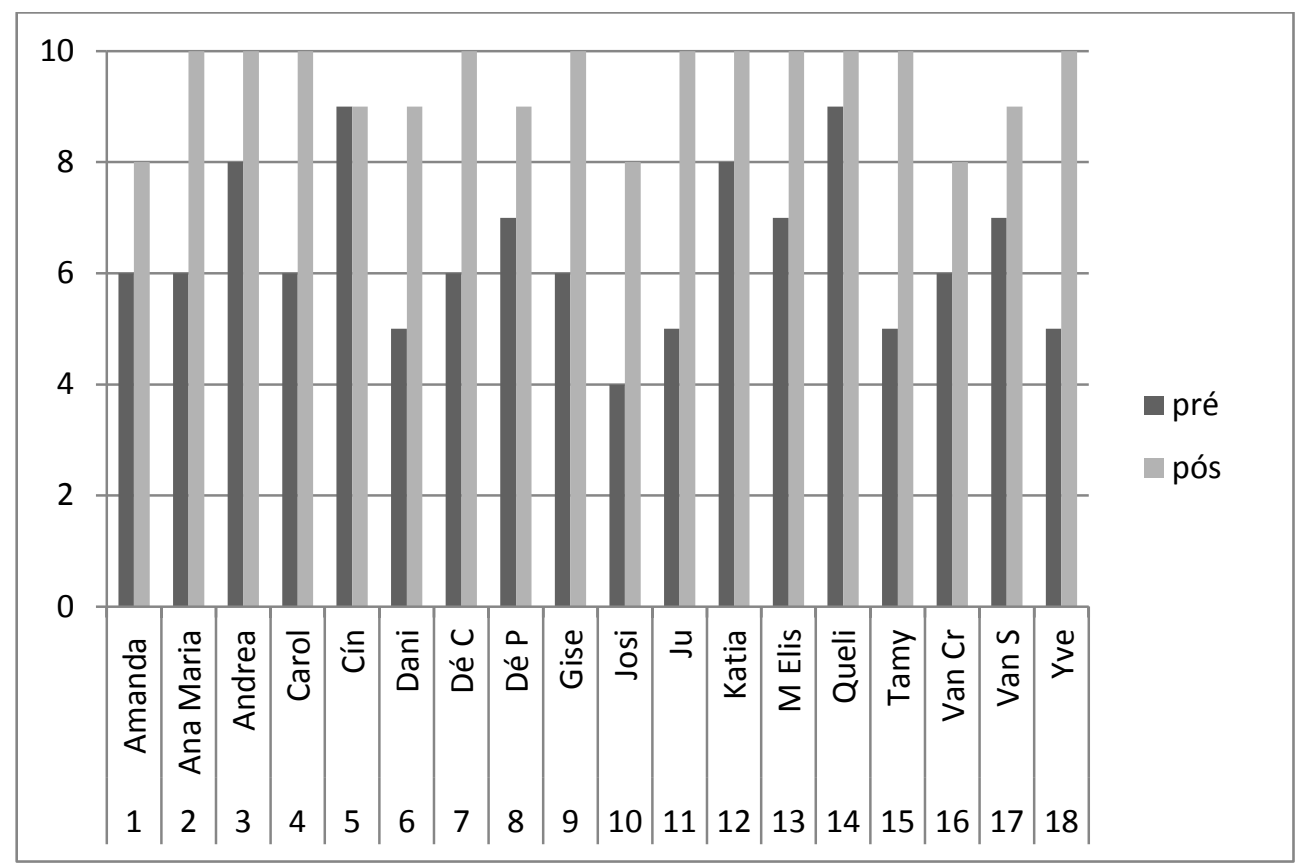

Gráfico 3 - Acertos do teste pré e pós-curso.

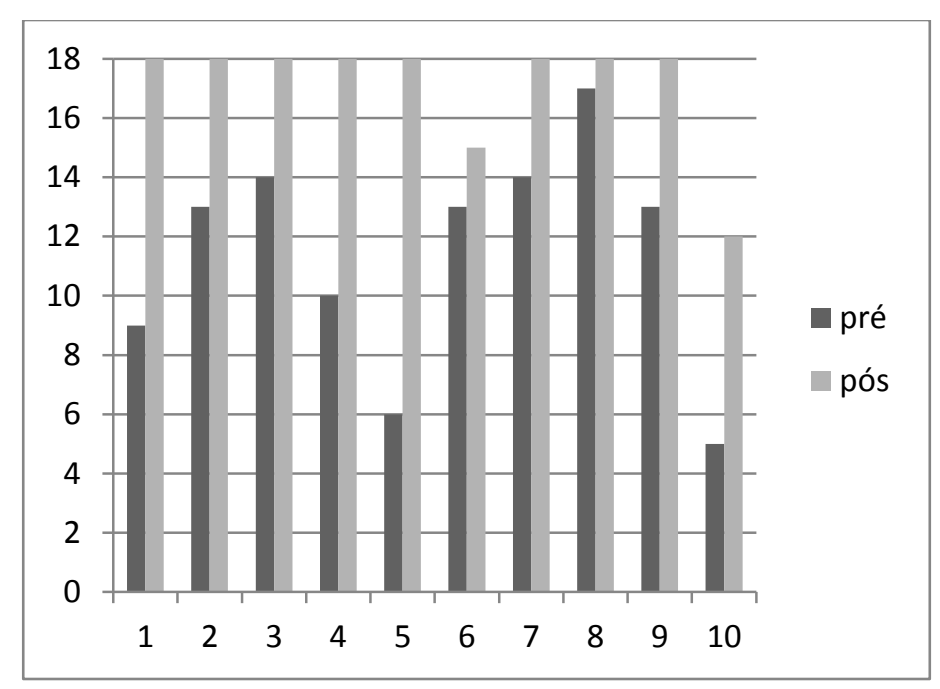

No geral houve um aparente aprendizado de todas as professoras. Consideramos "aparente" porque os testes não foram justificados majoritariamente, apesar da solicitação da justificativa. Baseando-nos no desempenho geral, teceremos comentários sobre algumas questões.

A questão 1 refere-se à identificação dos fenômenos ópticos de reflexão e absorção na visão da cor de um objetos opaco colorido. A questão 4 tem como obejtivo identificar os fenômenos ópticos de transmissão e absorção em filtros e 
vitrais. Acreditamos que o erro no pré-teste seja oriundo da não consideração da absorção da luz. A ideia de absorção é mais abstrata que a de reflexão e transmissão da luz. No primeiro dia do curso quando apresentamos os conceitos de reflexão, absorção e transmissão da luz, a dúvida foi sobre a absorção. No curso anterior, uma professora de Arte manifestou a mesma dúvida.

A questão 5 apresentou o maior aproveitamento. A mistura de luz vermelha e luz verde resultando em luz amarela costuma apresentar muito erro porque se confunde com a mistura de pigmentos. Em ambos os cursos, as professoras se interessaram em especial pela mistura aditiva de cores e as cores primárias de luz. Diziam que não era totalmente desconhecido mas não conheciam os fundamentos.

As questões 6 e 10 apresentaram a maior taxa de erro. Vamos discuti-las com mais detalhes.

\section{Questão 6.}

Objetivo: verificar a compreensão da mistura subtrativa de cores.

Afimativa - Tinta vermelha misturada à tinta verde resulta na cor preta ou quase.

Resposta esperada: Verdadeira. $\mathrm{Na}$ mistura subtrativa, tinta vermelha adicionada à tinta verde resulta em preto numa situação ideal com pigmentos puros e adicionados na mesma quantidade. Numa situação real, em geral obtém um tom escuro como marrom ou verde escuro.

Ao longo do curso enfatizamos a precisão linguística, supomos que as professoras que assinalaram "falso", consideraram a cor obtida ao realizarem as misturas de tinta verde com tinta vermelha durante o curso, em geral marrom ou verde escuro. Talvez tenham entendido "quase preto" como cinza escuro. Inferimos essa hipótese baseando-nos na justificativa:

Gis. "Falso. Marrom não é quase preto."

\section{Questão 10}

Objetivo: verificar a diferenciação entre as cores observadas do espectro e as sete cores disseminadas nos textos didáticos.

Afimativa - O arco íris contém sete cores. 
Resposta esperada: Falso. A quantidade de cores do arco íris depende da percepção da cada indivíduo.

Conjecturamos que o conhecimento disseminado institucionalmente prevaleça sobre o entendimento de que as cores visíveis do espectro da luz ou do arco íris dependem da percepção das cores do indivíduo. No curso anterior, quando perguntamos quantas cores os professores observavam no espectro da luz através do espectroscópio, todos os participantes responderam sete cores, inclusive um professor daltônico. Da fala de uma professora:

Queli . "Falso. Relativa - porque eu por exemplo só enxergo 6 cores, não vejo a diferença entre o violeta e azul, mas os livros didáticos apontam como sete cores."

Ao escrever "relativa" e mencionar os livros didáticos, a professora parece-nos sugerir um conflito entre aquilo que observou e o conhecimento institucionalizado.

Por outro lado, a questão 10 obteve uma variação positiva alta, podendo indicar uma ressifignicação do conhecimento prévio.

\subsubsection{Imagens das pinturas da série da Catedral de Rouen por Monet}

Nesta questão, o objetivo é avaliar a compreensão de que a percepção da cor depende da luz incidente. Na avaliação das respotas desta questão, consideramos o uso dos conceitos abordados durante curso avaliando o desenvolvimento da linguagem.

Dos 18 questionários entregues, foram avaliadas 17 respostas pois uma professora não respondeu esta questão. Realizamos a contagem de vocábulos/termos (tabela 4 e gráfico 4) a fim de analisarmos a mudança de linguagem pré e pós-curso verificando o uso de conceitos/termos cotidianos e científicos. De uma maneira geral, as professoras relacionam a variação da luz incidente com a mudança na percepção da cor de uma mesma superfície. Nas respostas do fase pré-curso, houve maior menção da influência da posição do sol, do horário e da estação do ano na luminosidade ambiente. 
Tabela 4 - Contagem de vocábulos e termos na avaliação pré e pós-curso na questão de avaliação dissertativa.

\begin{tabular}{|c|c|c|}
\hline Vocábulos/termos & $\begin{array}{c}\text { Pré- } \\
\text { curso }\end{array}$ & $\begin{array}{c}\text { Pós- } \\
\text { curso }\end{array}$ \\
\hline Luz e matéria; interação luz matéria & 0 & 3 \\
\hline Incidência; luz incidente & 2 & 14 \\
\hline Luz bate & 1 & 1 \\
\hline Luz refletida; reflexão & 6 & 10 \\
\hline Absorção & 1 & 8 \\
\hline Transmissão & 0 & 4 \\
\hline Refração & 2 & 2 \\
\hline Sombra & 3 & 1 \\
\hline Luz ambiente; luminosidade; iluminação & 12 & 1 \\
\hline Intensidade de luz & 3 & 2 \\
\hline Quantidade de luz & 1 & 0 \\
\hline Frequência das ondas & 1 & 0 \\
\hline Posição do sol & 1 & 0 \\
\hline Ângulo do sol & 0 & 1 \\
\hline Pigmento & 0 & 1 \\
\hline Percepção & 9 & \\
\hline
\end{tabular}

Gráfico 4 - Contagem de termos específicos na questão dissertativa de avalição pré e pós-curso.

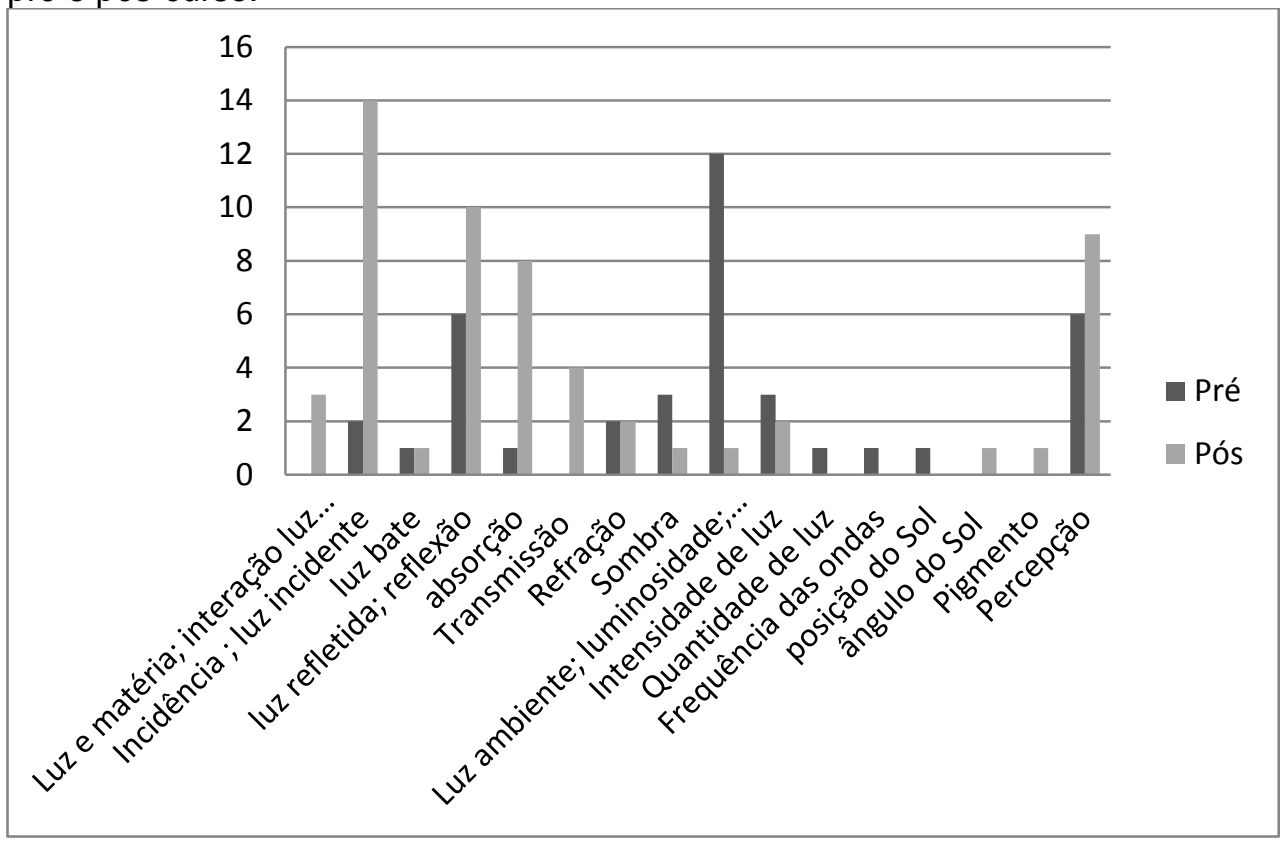


No geral, o emprego de termos científicos aumentou. Há um indicativo da substituição de luz ambiente, luminosidade, iluminação por luz incidente. A seguir transcrevemos ${ }^{34}$ e analisaremos algumas respostas signfinificativas.

A melhor resposta, indicando um potencial de aprendizagem maior.

\section{Cíntia}

Pré - A percepção da cor depende de como a luz é absorvida pelo objeto e da frequência das ondas refletidas. Também depende de como o cérebro "interpreta" as informações recebidas (daltônicos, por exemplo) [aspas da professora] .

Observando as pinturas, os horários do dia também influenciam na percepção através da intensidade da luz e das cores dos raios.

Pós - A percepção da cor se dá por vários processos diferentes e Monet procurou retratar as diferenças através das pinturas. Além da absorcão e da reflexão da cor no objeto, a cor da luz que incide sobre o objeto também pode modificar a percepção da cor. Para enxergar uma cor, a luz deve bater no objeto, que absorve as cores da luz e então ela reflete a cor que não foi absorvida. Essa cor refletida é a cor que enxergamos. Para a percepção do ser humano, ocorrem processos neurobiológicos que resultam na percepção da cor observada.

Observação - Foi a única a mencionar frequência de onda e intensidade da luz na fase pré-curso. E na pós a única a explicar o processo de percepção de cores. Estranhamente, descuidou-se ao utilizar bater ao invés de incidir, termo que já havia utilizado.

Algumas respostas apresentam ideias semelhantes mas o emprego de uma linguagem mais técnica após o curso. Grifamos os termos que mudaram do conceito cotidiano para o científico.

\section{Amanda:}

Pré - Que a luz do ambiente influencia diretamente a percepção das cores, por exemplo, a localização do sol

Pós - A luz incidente na catedral interfere na percepção da cor. No quadro W1321, podemos inferir que a luz incide em menor quantidade.

\footnotetext{
${ }^{34} \mathrm{Na}$ transcrição mantivemos as grafias originais com erro para transmitirmos a qualidade da escrita da professora importante para termos noção de sua formação básica. Escrevemos sic somente no final do texto original para deixá-lo mais fluente.
} 
Observação - Melhoria na linguagem semântica e sintática. Maior especificidade ao indicar o quadro a que se refere (O portal cinzento), aplicando o conceito corretamente ao relacionar aparência acinzentada à diminuição de luz incidente.

Quéli

Pré - A percepção das cores varia de acordo com a luz/iluminação que incidi sobre o objeto observado, demonstrando uma inconstancia da luz, cor e atmosfera. [sic]

Pós - A cor é resultado da interação luz/matéria, por isso intensidade da luz incidente faz com que "enxerguemos" certas cores ou sombras...

Observação - Quando escreve "luz/iluminação" parece-nos que tem dúvida em que palavra utilizar. No texto pré, utilizou "percepção" e na pós "enxerguemos" entre aspas, indicando o emprego figurado da palavra.

Van $S$.

Pré - [1] Desconheço os conceitos científicos, porém, com base em minha percepção e vivências, acredito que as mudanças de cores na catedral acontecem devido a posição do sol e quantidade de luz. [2] As formas presentes na arquitetura também devem ter influência, considerando que algumas áreas receberão mais luz que outras.

Pós - De acordo com o horário e época do ano a quantidade-[rasura da professora] incidência de luz solar será diferente, assim como o ângulo do Sol. Isso influenciará em quais cores serão refletidas.

Observação - Inicialmente a professora anuncia seu desconhecimento científico. No texto pós, referiu-se somente à parte [1]. Apresenta maior objetividade na sua explicação com relação às causas da variação da luz incidente ao mencionar horário e época do ano e ângulo do Sol. Escreveria novamente quantidade mas corrigi-se, escrevendo incidência. Trocou posição por ângulo, apesar da primeira ser um termo científico. Ela foi a única do grupo a relacionar a forma do objeto (a catedral) como fator de influência na percepção visual, como escreve na parte [2] da resposta pré.

Em quatro casos, as professoras apenas escreveram as palavras sem explicação. Os termos reflexão, absorção, transmissão e refração foram utilizados sem explicação, como palavras avulsas, indicando o pensamento por complexo e não conceitual. Como no exemplo, 
Josi

Pré - lluminação (luz/reflexo solares) influenciam na percepção e na coloração de um determinado objeto.

Pós - [1] A luz incidente interfere na percepção da cor do elemento observado.

[2] Os conceitos relacionados são os da luz com a matéria são reflexão, absorção e transmissão.

Observação - A parte [1] da resposta pós é uma reelaboração objetiva e conceitual do texto pré. Na parte [2] temos um exemplo de pensamento por complexo onde apenas nomeia os conceitos como numa associação livre. Sem explicação é impossível sabermos se o conceito está correto. Houve mais três casos de professoras que responderam por complexo reflexão, absorção e transmissão.

Alguns casos específicos iremos analisar individualmente.

Carol

Pré - A percepção da cor depende da quantidade de luz refletida na catedral. O que também nos traz a ideia de calor. Quanto mais iluminado maior a riqueza de detalhes, clareza das cores e supostamente seria devido a incidência do sol e a porção da catedral em horário mais quente e iluminoso do dia [sic].

Pós - A luz incidente na catedral interfere na percepção da cor. No primeiro quadro (O portal do tempo cinzento) podemos concluir que o resultado da catedral retratada em cores mais escuras se deve a menor incidência de luz [CERTO]. Aqui a maior parte da luz recebida foi absorvida [ERRADO]. Enquanto os quadros W1322, W1324, W1326 estão mais iluminados, portanto reflete mais luz [CERTO] [sic]

Observação - Na fase pré, esta professora já emprega conceitos científicos. Procura explicar relacionando a intensidade da luz incidente e refletida. Inferimos que a palavra "calor" foi associada com o horário de maior "incidência do sol", termo mencionado por ela na sequência de sua narrativa. Por estes termos, percebemos confusão conceitual e falta de precisão de linguagem. Na fase pós, há uma melhoria semântica e sintática. A redação do texto está melhor, ela separa em casos e referencia o que está explicando. "Incidência do sol" troca por "incidência de luz"; procura explicar as percepções variadas de cor relacionando a mudança da luz incidente com a luz refletida. Acerta quando diz que "cores mais escuras se deve a menor incidência de luz" no entanto, confunde com uma superfície pintada com cor escura que absorve mais luz. O objeto concreto - superfície escura - pode ser explicado das duas maneiras, indicando que ainda o pensamento da professora transita entre o pensamento por complexo (pseudoconceito) e o conceitual. 


\section{Daniela}

Pré - A luz tem total influência sobre as cores. De acordo com sua intensidade é possível observarmos diferentes tons em um mesmo objeto.

Pós - A luz influencia as cores que irão ser refletida, dependendo do pigmento do objeto irá subtrair a cor absorvida e refletir a cor do objeto [sic].

Observação - A explicação pós curso está correta mas não para este caso em que a mudança de cor se deve à mudança de superfície material. Um caso de pseudoconceito, onde o pensamento visual concreto foi utilizado.

Ana

Pré - [...] Arriscaria dizer que o conceito de refração da luz na atmosfera é responsável pelos diferentes efeitos das cores.[...]

Pós - [...] Refração da luz na atmosfera e reflexão da luz na superfície da fachada. [Grifos no original.]

Observação - A palavra refração é utilizada no lugar de espalhamento. Inferimos que Ana reconhece a influência da atmosfera na mudança de coloração da luz solar mas desconhece o fenômeno de espalhamento da luz, pouco abordado em cursos de Física do ensino básico, que também não incluímos no nosso curso. $O$ pseudoconceito surge pois observamos componentes da luz solar na refração e no espalhamento.

\subsection{Doces coloridos - atividade lúdico experimental}

Após observar a bandeja com doces coloridos iluminados por uma luz monocromática, cada grupo anotou no quadro a quantidade de cores observadas. Com o ovinho branco todos observaram apenas uma cor, igual a da luz monocromática. Sob iluminação da luz verde, a minhoca de gelatina variou entre 3 a 5 cores observadas, o amendoim colorido de 5 a 8 cores, a pastilha colorida de 5 a 7 cores.

A formadora conduziu a discussão com a turma sobre as causas das diferenças de cores. No final, as professoras-alunas escreveram suas respostas. 
Quadro 2- Quantidade de cores dos doces observadas por cada grupo (preto, vermelho e azul)

\begin{tabular}{|c|c|c|c|c|c|c|c|c|c|c|c|c|}
\hline & \multicolumn{3}{|c|}{ Ovinho branco } & \multicolumn{2}{|c|}{ Minhoca de gelatina } & \multicolumn{3}{|c|}{ Amendoim colorido } & \multicolumn{3}{|c|}{ Pastilha colorida } \\
\hline Verde & $\mathbf{1}$ & $\mathbf{1}$ & $\mathbf{1}$ & $\mathbf{5}$ & $\mathbf{5}$ & $\mathbf{3}$ & $\mathbf{8}$ & $\mathbf{7}$ & $\mathbf{5}$ & $\mathbf{6}$ & $\mathbf{7}$ & 5 \\
\hline $\begin{array}{c}\text { Vermelh } \\
\text { o }\end{array}$ & $\mathbf{1}$ & $\mathbf{1}$ & $\mathbf{1}$ & $\mathbf{3}$ & $\mathbf{4}$ & 3 & $\mathbf{4}$ & $\mathbf{2}$ & 3 & $\mathbf{3}$ & $\mathbf{3}$ & 4 \\
\hline Azul & $\mathbf{1}$ & $\mathbf{1}$ & $\mathbf{1}$ & $\mathbf{4}$ & $\mathbf{3}$ & 3 & $\mathbf{6}$ & $\mathbf{6}$ & $\mathbf{6}$ & $\mathbf{6}$ & $\mathbf{5}$ & $\mathbf{5}$ \\
\hline Branco & $\mathbf{1}$ & $\mathbf{1}$ & $\mathbf{1}$ & $\mathbf{5}$ & $\mathbf{5}$ & $\mathbf{4}$ & $\mathbf{8}$ & $\mathbf{9}$ & $\mathbf{7}$ & $\mathbf{6}$ & $\mathbf{7}$ & $\mathbf{7}$ \\
\hline
\end{tabular}

O relato de Ana sumariza a discussão da classe. Ela elenca seis fatores sobre as causas da difença de percepção das cores: [1] ângulo visual, [2] nomenclatura das cores, [3] tempo de observação, [4] problemas de visão, [5] material, [6] cor da luz incidente.

Ana

[...] diferentes tipos de doces de diferentes cores, observados sob luzes de cores diferentes [...].

Após a experiência discutimos sobre os diferentes resultados dos grupos, que apresentam a percepção de um número variado de cores, de quantidades de cores percebidas. Como possibilidades que justificaram essas diferenças foram elencados alguns itens, como por exemplo, [1] ângulo de visão; [2] nomear cores de forma diferente, considerando ou não diferentes tonalidades; [3] tempo de observação [...] , [4] problemas de visão de um participante, q. [sic] revelou a incapacidade de perceber o objeto,[...], ou mesmo, observação com ou sem óculos, feitas por outro participante, atestando relevantes alterações da percepção. $O$ [5] tipo de doce também foi condicionante da percepção já que um dos tipos, a gelatina, era transparente, afetando a percepção das cores [...]

[Sobre a dificuldade em contar os doces] Em alguns momentos [6] as cores pareciam se transformar, principalmente sob a luz verde. [...]

A influência do material na percepção da cor e da cor da luz incidente apareceu melhor nas falas de Ju.

[...] A luz mistura com a cor do alimento modificando-o. Ex. luz vermelha no alimento verde enxergávamos marrom. A transparência também influencia no reflexo das cores. A cor da luz irá interferir e modificar a cor do doce. [sic]

Por que a mudança da cor da luz altera o reflexo emitido pelo objeto causando uma confusão em nossas vista, fazendo com que reflita apenas as cores que não forem absorvidas apresentando uma alteração na quantidade em cada cor colocada, pois a que estão em estado de sombra não é possível enxergá-las. [sic] [Sobre a dificuldade em contar os doces coloridos.] 
O ângulo visual, a posição do observador apareceu com frequência. Este fator não era esperado. Grupos grandes, com oito pessoas, o espaço pouco adequado, impossibilitando uma boa posição de observação para todos os membros do grupo e a área de iluminação da bandeja com doces pequena podem ser as causas da dificuldade de visualização dos doces.

A nomenclatura das cores foi citado por Ana e na fala de Gis:

E a nomeamos associando a cores pré-estabelecidas como aprendemos desde a infância e as associando com nomes de alimentos ou frutas ou coisas. Ex: caramelo, guaraná, goiaba...

Nomear cores de acordo com o elementos do ambiente concreto é uma características do pensamento concreto visual, conforme Vigotski (1996) e Luria (2017).

No geral, esta atividade parece-nos efetiva para conscientizar sobre a subjetividade na percepção da cor. Este aspecto predominou entre as professoras.

Gis - A percepção da cor é individual e cultural.

Kátia - Como vemos as cores? De acordo com a percepção de cada com a luz ambiente [sic] .

Josi - Não encontramos dificuldades na contagem de cores dos docinho [sic], apenas em enxergar, enquanto grupo as mesmas cores, alguns não percebiam algumas cores [duplo grifo da professora].

Cíntia - A partir da demonstração, também é possível concluir que a percepção da cor, além da influência dos fenômenos físicos (absorção, reflexão, frequência, cor da luz) também é influenciada pelo repertório e particulares [sic] de cada indivíduo.

A linguagem pictórica, conforme vimos perspectiva histórico cultural, é uma forma de comunicação mais acessível por expressar o pensamento visual concreto. O experimento com os doces coloridos foi representado artisticamente por algumas professoras nos "livros de arte" produzido como síntese do conhecimento aprendido durante o curso. $\mathrm{Na}$ figura 26, a professora percebeu que o efeito do filtro luminoso (papel celofane) como substituto das lâmpadas monocromáticas. A fim de rerpesentar a diferença das cores dos "doces" iluminados por luz branca e por luz colorida, ela colou o papel celofane somente numa borda. 
Figura 26 - Representação artística do experimento com doces coloridos iluminados com luzes monocromáticas. Desenho com giz de cera e colagem com papel color set e celofane.

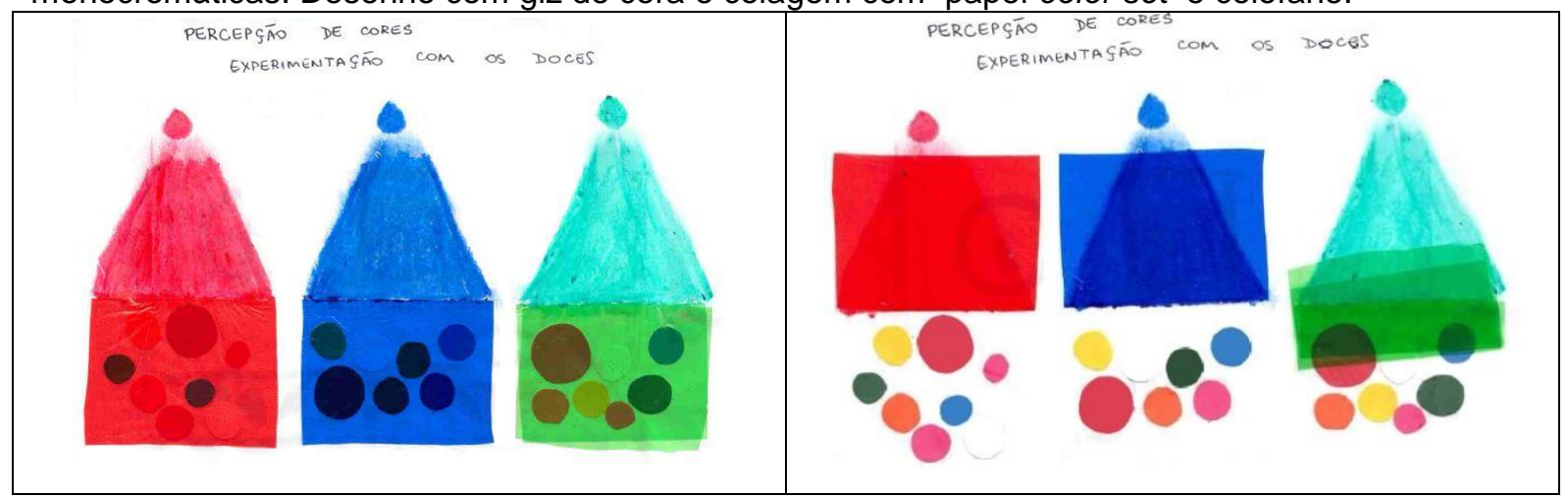

Crédito da obra: Carol.

O desenho seguinte (figura 27) foi a capa de apresentação do "livro de arte" de Ana. Inferimos que a professora representou a variação da cor dos doces nas quatro cores de luzes que utilizamos. O amendoim branco permanece branco quando iluminado pelas luzes branca, verde e vermelha, e tornou-se rosado sob a luz azul. O amendoim branco é percebido branco somente sob luz branca. Sob iluminação colorida, a cor do amendoim será da mesma cor da luz incidente. Por exemplo, quando iluminado pela luz vermelha, o amendoim é visto vermelho; sob luz azul, azul. O desenho foi realizado pela memória visual da professora. Este erro no desenho pode ser um indicativo de um problema na aprendizagem de formação de cores, talvez oriundo da frase "o branco reflete todas as cores" que dita desta forma está incompleta podendo induzir ao erro conceitual. Nossa hipótese baseia-se na representação aparentemente correta da cor dos doces coloridos quando iluminados pelas diferentes luzes.

Figura 27 - Representação artística do experimento com doces coloridos iluminados com luzes monocromáticas. Desenho com giz de cera.

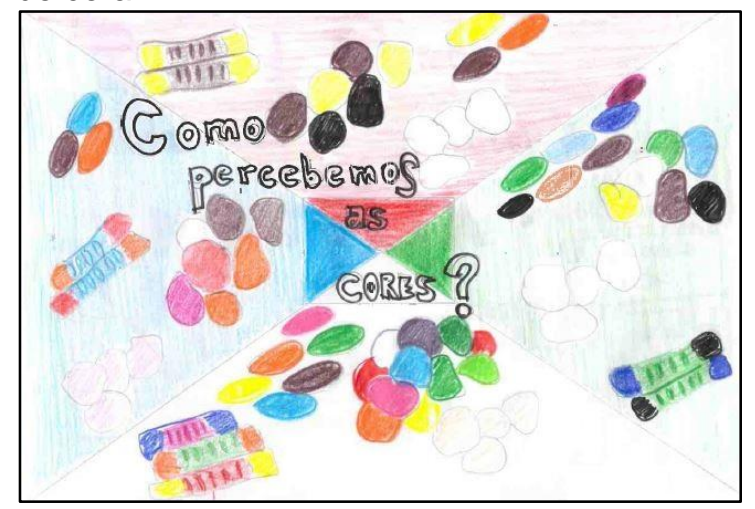

Crédito da obra: Ana. 
O "livro de arte" como instrumento de coleta de dados, permite-nos extrair informações de diferentes natureza. Andrea produziu um "livro-diário", registrando sua memória e percepção emocional principalmente (figura 28). No trecho que destacamos a seguir, podemos perceber a importância da realização de atividades experimentais para a compreensão conceitual.

Andrea. [...] durante as explicações sobre os processos de interação entre luz e matéria não estava sendo muito compreendida de minha parte.

Iniciei uma compreensão melhor quando descemos para o laboratório (blackout) e houve observação de objetos (doces: confetes, amendoins, minhocas gelatinosas, amendoins ovinhos) sob a incidência das luzes verde, vermelha e azul.

Notamos que na página onde ela relata sua dificuldade de compreensão, escreveu conceitos científicos soltos, relacionados com a explicação da lousa dada pela professora formadora. Na página seuinte, quando narra a melhora na compreensão, associa os conceito científicos com palavras do cotidiano.

Figura 28 - Trecho do livro-diário da professora mostrando a importância de atividades práticas para a aprendizagem.
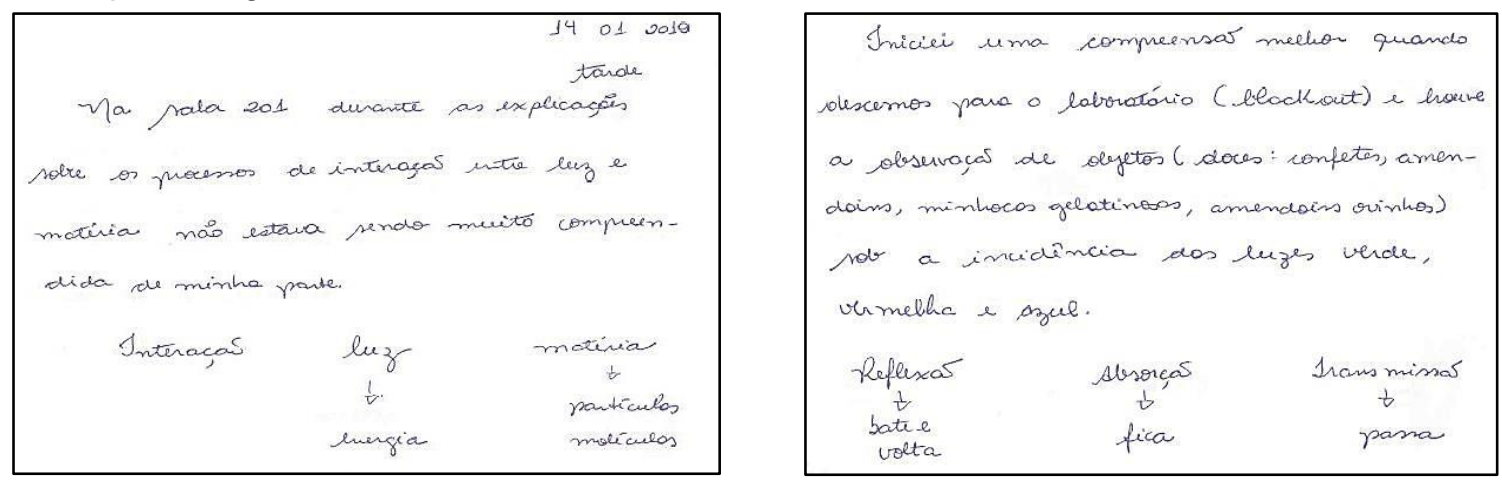

Crédito: Andrea 


\subsection{Interação luz matéria - atividade artístico experimental}

Foram criados seis paineis artísticos. Os dados foram coletados da transcrição da gravação das apresentaçãoes e de relatórios realizados no final da atividade. Selecionamos os dois seguintes em função da qualidade dos relatórios.

Figura 29 - Mandala. Colagem de materias diversos.

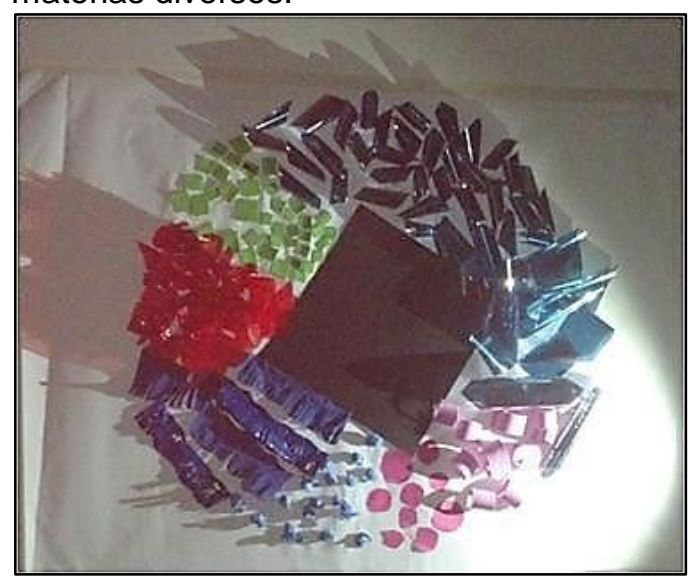

Créditos da obra: Denise, M. Elis, Queli, Tamy.
Figura 30 - Blue Black. Colagem de materias diversos.

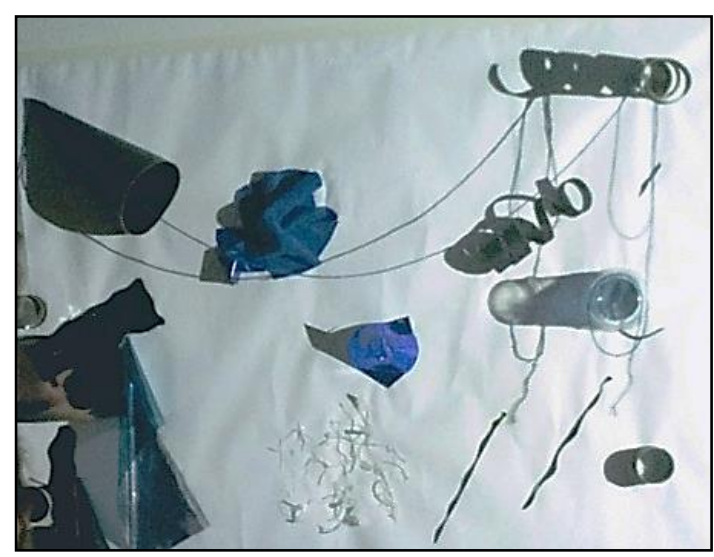

Créditos da obra: Dé P., Dé C., Ive., Gi.

Os grupos apresentaram seus trabalhos na sala escura. Enquanto expunham as ideias da concepção do painel, destacavam os diferentes efeitos da interação da luz com o material incidindo a luz da lanterna do smartphone.

Do grupo Mandala (figura 29).

\section{Apresentação oral:}

De - Nós quisemos explorar não só a cor como também o reflexo, a opacidade, a forma.[...]

Tamy - A gente tentou explorar todas as inter-relações da matéria com a luz. A gente tentou explorar o máximo as texturas, as formas para tentar demonstrar todos os tipos de interação que a gente conseguiu com os materiais.[sic]

\section{Relatos individuais por escrito}

Queli - Transmissão - celofane - a luz é transmitida - sombra colorida [Refere-se à projeção da luz transmitida pelo celofane.]

Reflexão - materiais metalizados

Absorção - materiais opacos - cartão preto/E.V.A. verde 
Do grupo Blue Black (figura 30).

\section{Apresentação oral:}

Gi - A gente brincou com a questão de material... espaço. Então tem acúmulo de material num espaço... a gente tentou espalhar um pouco mais esse material diversificado. Daí tem um espaço de reflexão que reflete prata, que o reflete azul de um modo que você olha [sic]. A ideia é que seja explorado mesmo.[...] Ver cada cantinho, o volume... é proposital.

Yve - E a gente tem o azul fosco, o azul brilhante; o preto fosco, o preto brilhante. $\mathrm{E}$ como eles se relacionam um com o outro, com as outras cores também.

Gi - E o branco da cartolina brincando com o branco da cola quente. [Colaram fios de cola quente formando um aglomerado na parte inferior do painel.]

Yve - E o branco ali que deu a sombra que ficou preta. (risos)

\section{Relato do grupo por escrito}

Materialidade, tamanho, posição dos objetos interferem na percepção das cores da obra. Pode explorar as texturas da obra conforme a incidência do foco de luz em movimento lento. Nas partes prateadas/azuladas percebi reflexos da luz. $\mathrm{Na}$ cor preta fosca mais absorção. No copo de plástico houve parte de transmissão da luz. Na cola quente ... reflexão da luz.

Em ambos trabalhos as professoras procuraram explorar a formação de sombra através das formas tridimensionais, as diferentes propriedades de reflexão da luz utilizando materiais de texturas variadas, associadas à cor do objeto.

O grupo Blue Black buscou explorar as variações na reflexão difusa e especular em objetos de mesma cor - "azul fosco, o azul brilhante; o preto fosco, o preto brilhante" .

A ocorrência da reflexão, da absorção e/ou da transmissão na fala de Quéli são descritas como absolutas e isoladas em cada material. Inferimos que identifica somente transmissão no papel celofane, reflexão especular (reflexão - materiais metalizados) e absorção em materiais opacos (absorção - materiais opacos - cartão preto/e.v.a. verde). Já a fala de Andrea indica a percepção da ocorrência simultânea dos eventos ao descrever como cor preta fosca mais absorção ou no copo de plástico houve parte de transmissão da luz. Ao utilizar "mais" e "parte" parece indicar o entendimento da ocorrência conjugada da reflexão, da transmissão e da absorção.

Dos "livros de arte", destacamos a colagem de Ana com uma síntese didática dos fenômenos de reflexão (figura 31) utilizando diferentes tipos de materiais de sucata. 
Figura 31- Colagem sobre tipos de reflexão.

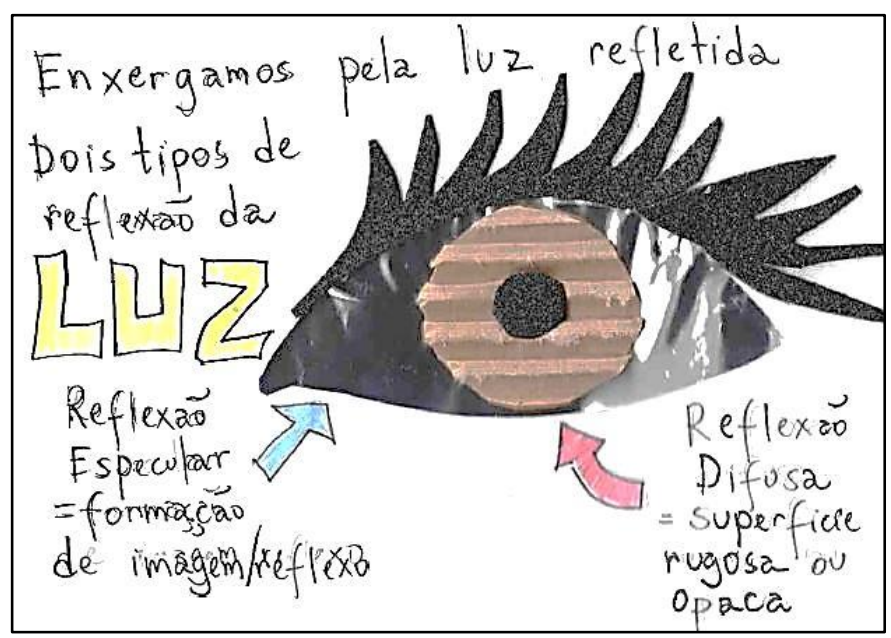

Crédito: Ana

Van S criou uma obra mais abstrata (figura 32) e Dé C. uma obra mais ingênua (figura 33).

Figura 32- Colagem sobre interação luz matéria

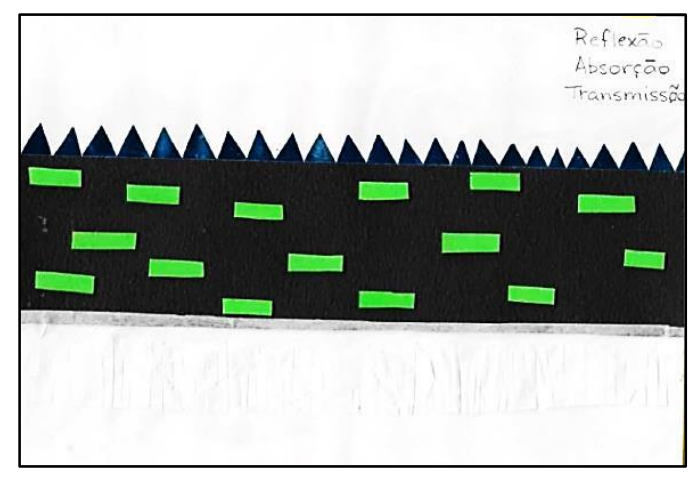

Crédito: Van S.
Figura 33 - Colagem sobre interação luz matéria

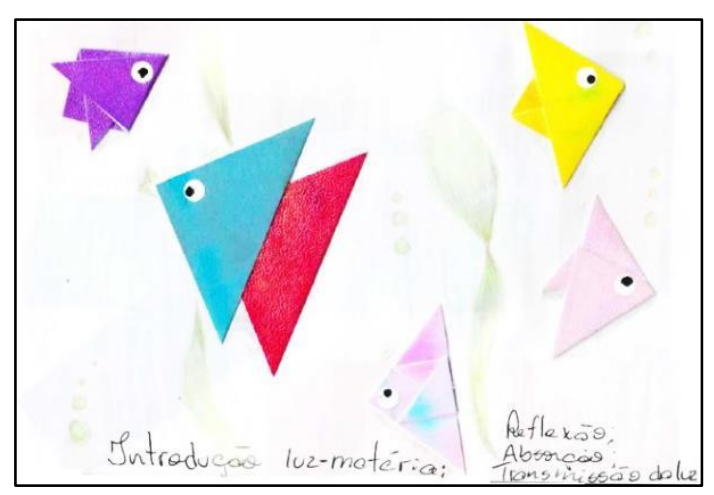

Crédito: De C

\subsection{Luminosidade de superfícies coloridas - atividade experimental}

\subsubsection{Identificação de variáveis}

As professoras descobriram como o luxímetro funcionava, realizando medidas em diferentes condições de luminosidade, comparando os valores lidos nos aparelhos das colegas. Identificaram como variáveis da medida da intensidade luminosa: intensidade da luz incidente - identificada como luz ambiente, incidência da luz, iluminação ambiente, luminosidade da sala; distância do aparelho à fonte de luz; ângulo da luz incidente ; a posição do aparelho ao captar a luz incidente; área da superfície refletora; sensor. 
$\mathrm{Na}$ etapa seguinte, as professoras observaram as folhas de papel coloridas dispostas no chão da sala, anotando qual cor refletia mais luz. Em seguida realizaram as medições com o luxímetro, compararam o resultado com sua hipótese procurando explicar a concordância ou não com sua conjectura.

\subsubsection{Experimentação}

Para nossa análise, consideramos somente as repostas qualitativas.

Andrea supôs que a cor amarela refletiria mais luz que a cor branca. Efetuou a medição três vezes; na figura 34 , dispôs as cores em ordem descrecente de iluminância. No seu registro, ela descreve seu raciocínio.

Figura 34 - Representação impressão emocional do experimento extraídos do "livro de arte" da professora.
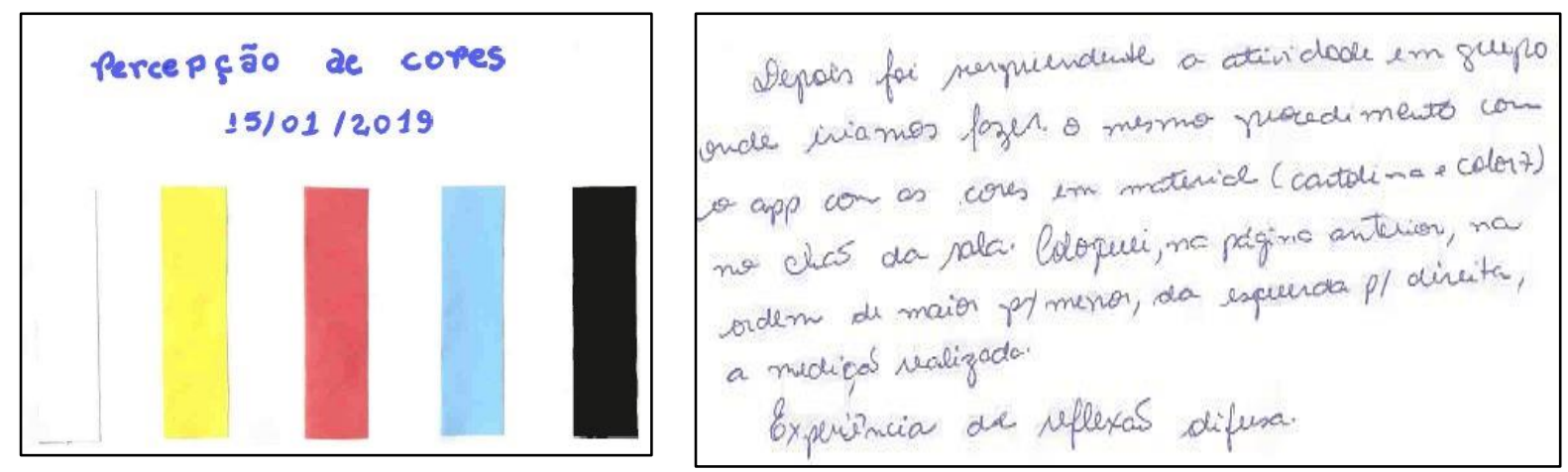

Crédito: Andrea

Andrea. (a) Achei que seria a cor amarela. Percebi mais reflexos da cor amarela que a cor branca. Talvez pelo papel (material diferente entre os dois). (b) Houve a suposição ... em relação das cores amarela e branca terem um valor maior na medição do que as outras três, já que em relação a cor preta acertei em ter o menor valor na medição. Acredito ser possível que a textura da cartolina por ser diferente do [papel] color 7 pode interferir (cartolina mais rugosa e os colors 7 mais lisos). Os piguimentos também podem interferir com a incidência da luz. (sic)

Andrea parece busca melhor elaboração do pensamento utilizando os conceitos ensinados como textura lisa e rugosa, pigmento e luz incidente que confundiu com luz refletida. Parece caminhar para um grau maior de abstração quando relaciona as características da superfície (rugosa ou lisa) e o efeito que luz refletida causa na percepção da cor, também no seu "livro" registrou "reflexão difusa", identificando o fenômeno. 
Nas respostas a seguir, encontramos alguns denominadores comuns.

Amanda. (a) Branca, porque reflete todas as cores. (b) Sim, porque o branco é chamado a cor da luz e reflete todas as cores.

Cíntia. (a) A hipótese inicial era que a folha branca refletiria mais luz devido ao conhecimento sobre o arco íris e a imagem icônica do Led Zeppelin (Dark side of the moon) [refere-se à capa do disco do conjunto de rock Pink Floyd e não do Led Zeppelin que traz a imagem de um prisma decompondo a luz branca.] A cor preta absorveria mais luz devido à vivência com roupas pretas e também com 0 conhecimento do arco íris. (b) O aplicativo confirmou a hipótese ao apresentar índice de lux mais elevado na cor branca, mostrando que ela reflete mais luz e o preto absorve mais luz.

Quéli. (a) Branco porque ele reflete mais luz. (b) Sim foi. [a hipótese inicial foi confirmada] O branco absorve pouca luz e reflete mais luz. O preto absorve muita luz e reflete pouca luz.

Tamyres. (a) Na minha opinião a cor que irá refletir mais é o branco, depois o amarelo, vermelho, azul e preto. Acredito que cores claras refletem mais a luz e cores escuras absorvem mais a luz. (b) Levando em conta a medição de três pessoas do grupo... os resultados foram como eu previa.

Van S.. (a) Acho que será o branco porque é a cor que percebo iluminar mais os ambientes quando usado na pintura das paredes e objetos. Também é um conselho frequente "utilizar roupas brancas" em dias de muito sol por ser a cor que "reflete a luz." (b) Sim, o valor medido corresponde com minha previsão. Pensando que o branco possui todas as cores e o preto é a ausência delas e, respectivamente, são as que mediram mais e menos lux entre todas as opções, imagino que a quantidade de lux absorvido acontece de acordo com a cor ausente no objeto.

As cinco professoras relacionam o fato da superfície branca refletir todas as cores com maior intensidade da luz medida e a cor preta ter maior absorbância. Amanda, Cíntia e Van S explicam relacionando com a vivência prévia. Amanda evoca o branco como "a cor da luz". Cíntia cita o arco íris e a capa do disco Dark side of the moon. Em ambos os casos, as imagens remetem mais para o espectro da luz branca. Vanessa explica melhor ao associar a iluminação ambiente com a cor das paredes, porém sem menção da luz refletida pelas paredes: "a cor que percebo iluminar mais os ambientes quando usado na pintura das paredes e objetos."

Inferimos que elas associam o fato da superfície branca refletir mais luz porque a luz branca contém todas as cores e todas as cores são refletidas. As explicações mais elaboradas basearam-se predominante na vivência pessoal. Percebe-se a influência sócio cultural no pensamento pré-conceitual. As palavras científicas que mais aparecem são reflexão e absorção. Quéli apresenta a compreensão de que há reflexão e absorção em todas as superfícies, percebe a 
variação na intensidade da luz refletida e da luz absorvida, um pensamento mais abstrato.

Dos "livros de arte" escolhemos dois exemplos criativos $\mathrm{Na}$ figura 35, a professora se baseou na obra de Mondrian indicado para pesquisa durante o curso. $\mathrm{Na}$ figura 36, a professora trabalhou com a linguagem de quadrinhos.

Figura 35 - Representação artística da atividade experimental. Colagem, papel color set, caneta hidrogáfica e giz de cera sobre sulfite.

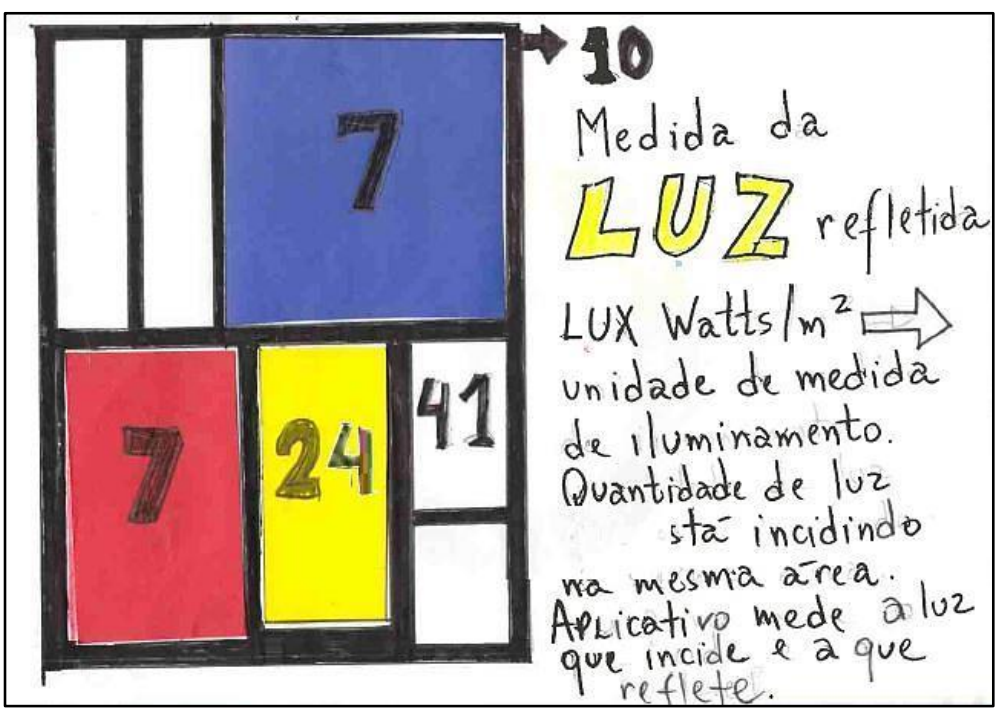

Crédito: Ana

Figura 36 - Representação artística da atividade experimental. O texto do lado direito diz: Imaginando o braço tostando. Grafite sobre sulfite.

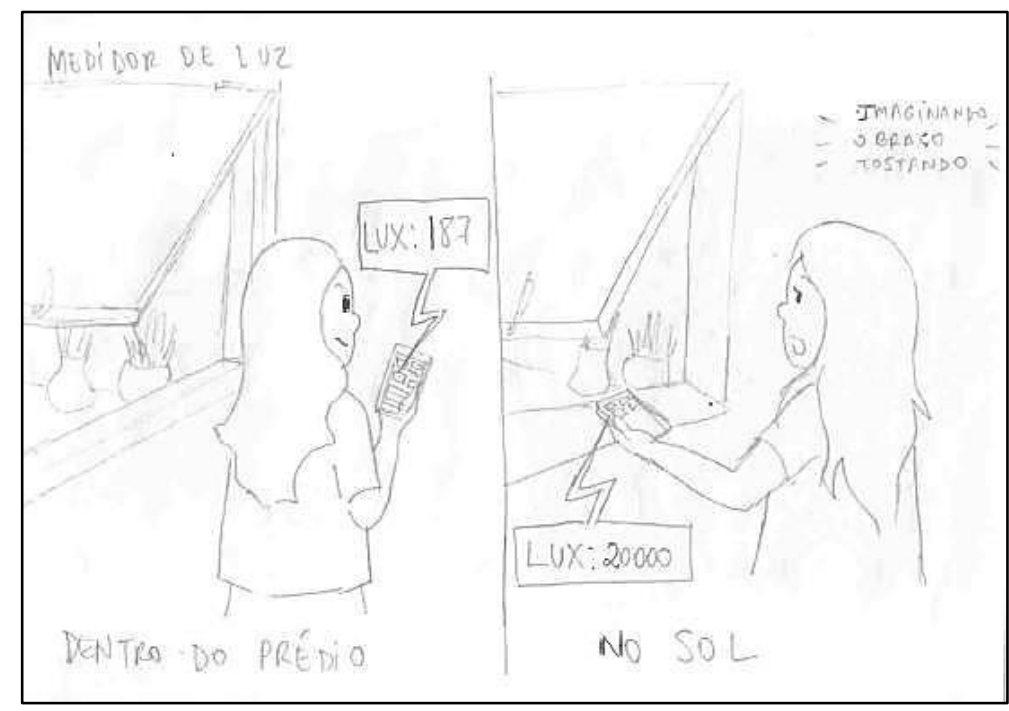

Crédito: Cintia 
Em função deste experimento, a atividade artística que surgiu por iniciativa das professoras foi explorar o efeito de aumento ou diminuição aparente consequência da variação da refletividade de luz da superfície, como vemos na figura 37.

Figura 37 - Expressão criativa baseada na refletividade das cores branco e preta. À esquerda colagem papel color set. À direita, caneta hidrogáfica sobre papel.
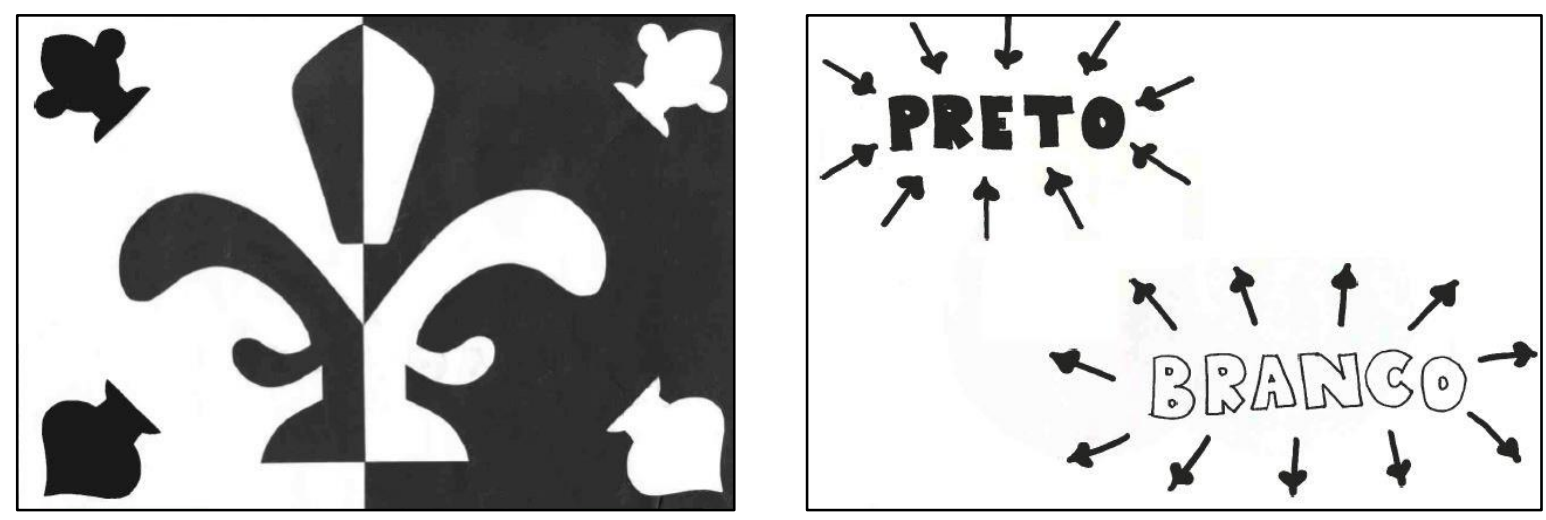

Crédito: Van C

Em um caso, inferimos que a professora entende que o branco reflete mais luz, mas utilizou um papel metalizado representando o branco (figura 38). Parece compreender o conceito de reflexão num nível generalizado, mas não diferencia a reflexão difusa (superfície opaca branca) da reflexão especular (superfície espelhada).

Figura 38 - Expressão criativa com a intenção de representar a diferença de refletividade das cores branco e preta. Colagem pale metalizado com película estrutural sobre papel color set preto.

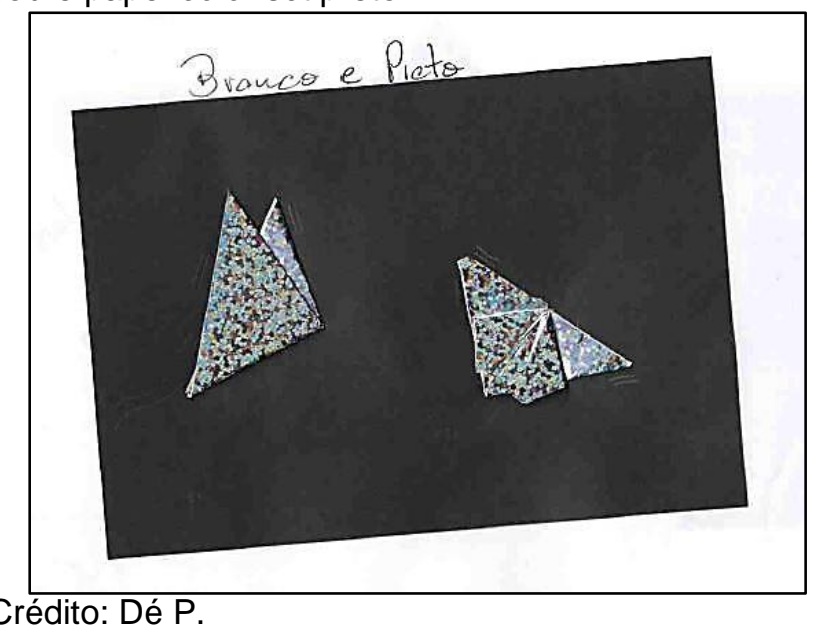




\subsection{Espectro da luz - atividade experimental}

As professoras observaram o espectro da luz da lâmpada fluorescente e da luz solar. Primeiro por um prisma de acrílico e depois por um espectroscópio de caixinha confeccionados por elas. Todas esperavam observar "as sete cores do arco íris" tanto pelo prisma como pelo espectroscópio. Vamos analisar as respostas das questões 2 e 3 selecionadas.

Andrea. Após a confecção [do espectroscópio] pude perceber 6 cores, um fecho menor que o que esperava, porém com cores bem vivas anil, verde, amarela, alaranjada e vermelha. (sic)

Os resultados foram diferentes ao que esperava, com a ajuda do espectro [espectroscópio] e a experiência de observação com prisma em ambientes [diferentes] aclarou para minha prática, ampliando meu conhecimento e agora corretamente. (sic)

Carol. [Pelo prisma observou vermelho, laranja, amarelo, azul e violeta. Pelo espectroscópio observou vermelho, laranja, amarelo, verde claro, verde escuro, azul e violeta]. Os resultados foram diferentes do que eu esperava pela quantidade de cores que foi possível obervar. No prisma não vi o verde e no espectro [espectroscópio] que "divide" a luz em mais cores que o prisma, eu observei dois tons de verde. Acredito que isso se deve às características do material utilizado.

Cíntia. [Pelo prisma observou vermelho, laranja, amarelo, verde e azul. Pelo espectroscópio observou vermelho, laranja, amarelo, verde escuro, verde claro, anil e violeta].

Os resultados foram semelhantes mas não esperava.. No imaginário esperava enxergar as tais 7 cores do arco íris. A diferença entre as cores do prisma e do espectômetro (sic) pode ser devido ao material utilizado (prisma/CD) e também à quantidade de luz (a luz ambiente pode ter influenciado na observação do prisma.

Elis. [Os resultados foram] diferentes, ao vermos o prisma esperamos encontrar 7 cores, segundo a teoria de Newton. Mas durante a decomposição da luz, devido à interferências da superfície este número poderá ser outro. (sic)

Quéli. Não, exatamente. Diferença dos tipos de luz (natural, artificial) e na interpretação das cores.

Tamy. Foram um pouco diferentes pois as cores acabam se fundindo, se misturando e no caso do espectro, podem ocorrer alguns erros na construção do espectroscópio e qualidade do CD.

Van S. [Observação pelo o prisma] As mesmas cores que esperava. Em algumas áreas com mais quantidade de amarelos, alaranjado, e vermelho, outras com mais azul e violeta. $O$ verde aparecia em uma faixa mais fina e em menor quantidade.

[Observação pelo o espectroscópio] As mesmas cores vistas no Prisma (sic), mas o verde estava mais fácil de visualizar e as cores mais saturadas. 
A menção do material indica que percebem a decomposição da luz como consequência da interação da luz com o material, como vemos nos relatos de Carol e Cíntia. Na fala de Cíntia: "A diferença entre as cores do prisma e do espectômetro (sic) pode ser devido ao material utilizado (prisma/CD)"

A relação entre a fonte de luz e o espectro observado, é apontada por Andrea e Cíntia ao se referirem à luz ambiente. E mais precisamente por Quéli: "Diferença dos tipos de luz (natural, artificial)..."

A utilização de instrumentos como elemento de mudança na qualidade da observação é mencionada por Andrea: " [...] a ajuda do espectro [espectroscópio] e a experiência de observação com prisma [...] aclarou para minha prática, ampliando meu conhecimento e agora corretamente".

A subjetividade na observação é indicada por Quéli ao se referir na interpretação das cores e por Cíntia e Elis ao mencionarem a influência do conhecimento prévio na observação:

Cíntia: "No imaginário esperava enxergar as tais 7 cores do arco íris";

Elis: "... ao vermos o prisma esperamos encontrar 7 cores, segundo a teoria de Newton."

Através dessa atividade é possível proporcionar a compreensão de que a observação do espectro da luz depende do material, da fonte de luz, do instrumento de observação e do observador; e, por fenômenos disitintos - por refração ou por difração da luz, embora isto não fora mecionado por nenhuma professora.

Após a realização do experimento, as professoras criaram um painel coletivo com as cores espectrais (figura 39), uma forma de verificar o conteúdo aprendido, e proporcionar atividade artística no tempo reduzido de sala de aula. Indicamos a pesquisa na internet das obras de Julio Le Parc que criou obras baseados nas cores espectrais. As criações apresentadas das figuras 40 e 41, parecem releitura de suas obras. Na figura 40, Van C. cria uma obra de síntese. Inferimos que comunica a luz como onda eletromagnética onde cada cor possui um comprimento de onda. 
Figura 39 - Painel coletivo com cores espectrais. Colagem de papel Color Set sobre sulfite.

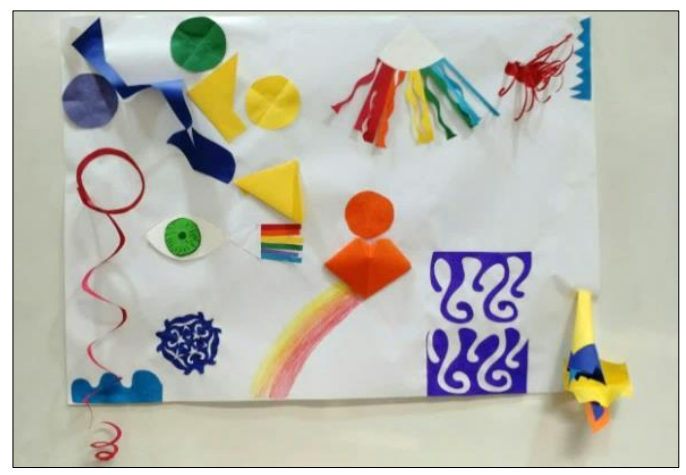

Crédito: Criação coletiva.
Figura 40 - Desenho síntese com cores espectrais. Lápis de cor e caneta hidrográfica sobre papel sulfite.

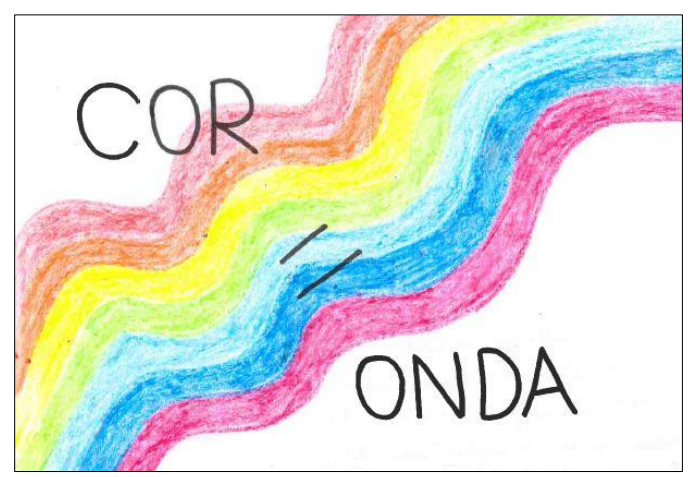

Crédito: Van C.

Figura 41- Representação artística do espectro da luz branca. Colagem, papel color set sobre sulfite.
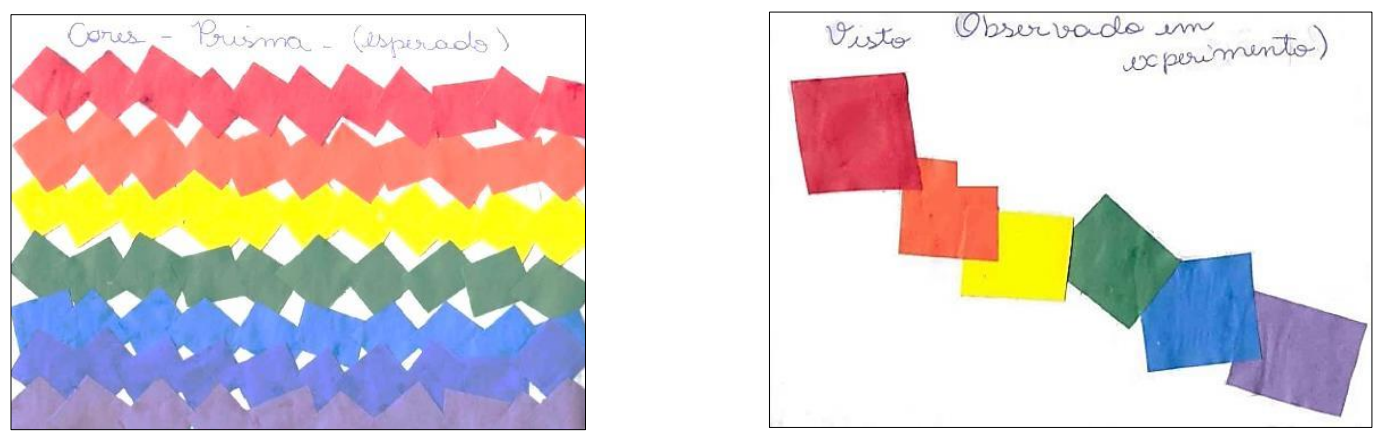

Crédito: Quéli

Na figura 42, Van S. representou criativamente o que observou na caixinha do espectrocópio (identificado por ela). Na obra que vemos na figura 43, parece-nos que a professora expressa as cores da pintura como fruto da decomposição do espectro da luz branca. Observamos que ela utilizou somente cores espectrais e inferimos que procurou representar as "partículas de luz", talvez influenciada pelo modelo particulado representado pelo aplicativo Visão de $\operatorname{Cor}^{35}$ - PHET, que utilizamos em aula para ilustrar a visão de cores.

\footnotetext{
${ }^{35}$ Disponível em https://phet.colorado.edu/pt BR/simulation/color-vision [ acesso em 06.07.2019]
} 
Figura 42 - "Espectroscópio", colagem, lápis de cor sobre sulfite.

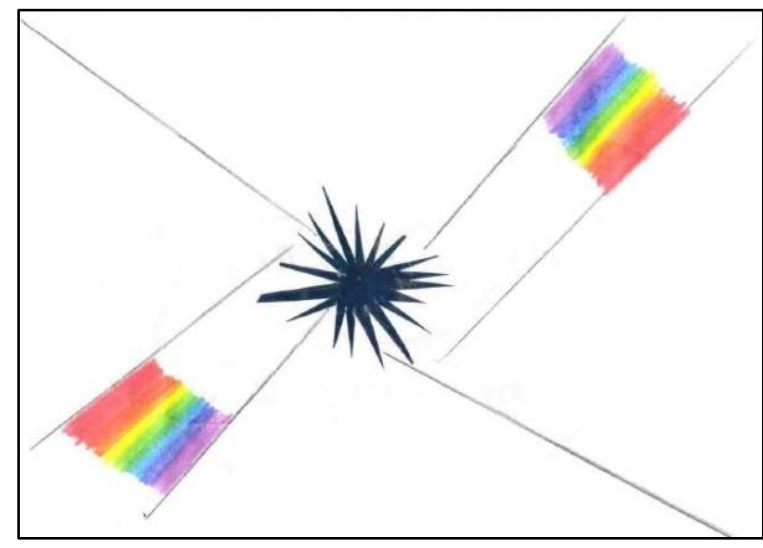

Crédito: Van S.
Figura 43 - As cores das pinturas como expressão da decomposição da luz branca.

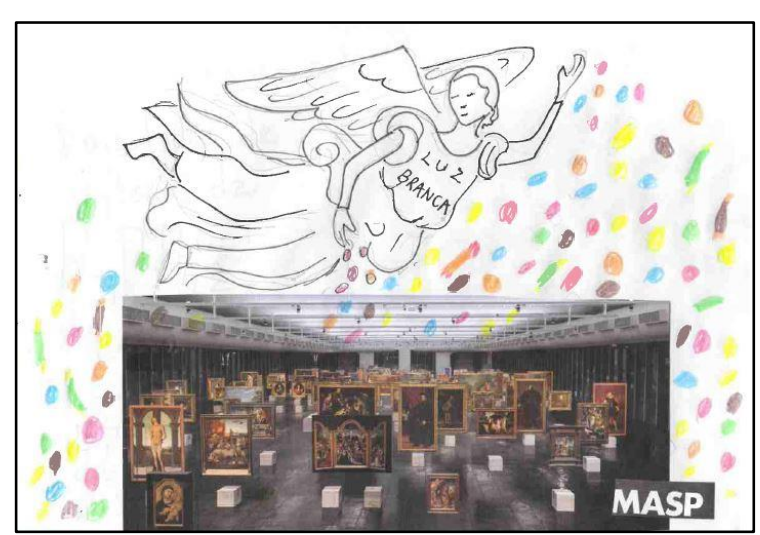

Crédito: Ana

Tamy explicou o processo de decomposição da luz no seu "livro de arte" e não no texto do roteiro da experiência (figura 44) e produziu uma obra com cores espectrais (figura 45).

Figura 44 - Decomposição da luz segundo registro no "livro de arte"de uma professora.

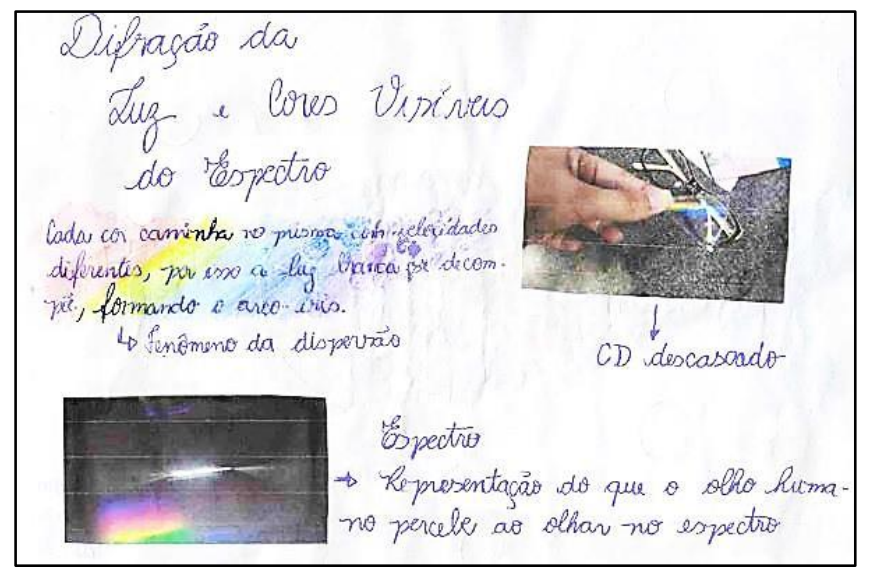

Crédito: Tamy
Figura 45 - Criação com cores espectrais. Colagem

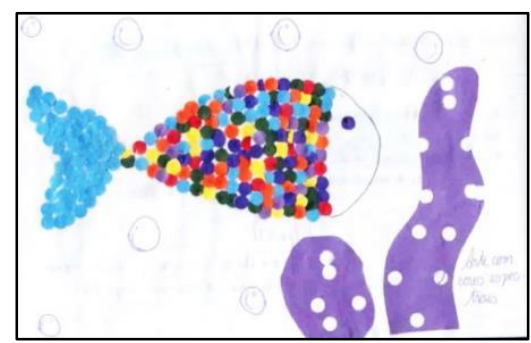

No texto do da figura 44, Tamy escreve

Cada cor caminha no prisma com velocidades diferentes por isso, a luz branca se decompõe, formando o arco íris. $\rightarrow$ Fenômeno da dispersão.

Ela explica corretamente a decomposição da luz por refração mas identifica o espectro da luz branca com o arco-íris, um pseudo conceito muito comum. No 
entanto, na justificativa do teste 10 sobre o espectro da luz, ela escreve corretamente:

"As cores do arco íris são as mesmas do espectro...."

Interpretamos esta oscilação conceitual como exemplo da força do conceito espontâneo sobre o conceito científico aprendido recentemente. A aprendizagem para sedimentar requer tempo e trabalho.

Observamos que em todos os trabalhos criatívos com cores espectrais, as professoras utlizaram as sete cores institucionalizadas, mesmo que não as observaram.

\subsection{Disco rotativo: mistura aditiva de cores - atividade experimental -}

No dia anterior, a mistura aditiva de cores fora demonstrada através de um aplicativo e no Laboratório de Demonstração do Instituto de Física da USP através do experimento de Sombras Coloridas. Todas professoras esperavam observar a cor branca quando o disco girasse.

Neste relato, a professora descreve sua observação e procedimentos, elabora e verifica a hipótese, não explica nem utiliza termos científicos. No novo disco, pintou com seis cores, percebeu que não são necessárias as sete cores para resultar branco. Os discos testados estão na figura 46, extraída do seu "livro de arte".

Andrea. Utilizei as cores vermelha, roxa, azul ciano, verde escuro, verde claro, amarela e alaranjada. Esperava ver, quando rodasse, um resultado branco. Utilizei as cores chapadas. ... Observei que não resultou a cor branca e sim a borda ficou azul anil e o centro ficou amarelado. O resultado não foi semelhante ao esperado. [hipótese] Suponho que ter colorido com sete cores, de maneira intensa e dois tipos de verde, acabou resultando na borda a cor azul e o meio amarelado.

[teste de nova hipótese] Confeccionei outro disco com seis divisões, utilizei ciano, verde claro, amarelo, alaranjado, vermelho e roxo, sem esquecer das tonalidades do escuro para o claro de dentro para fora. Deu certo, o resultado foi branco.

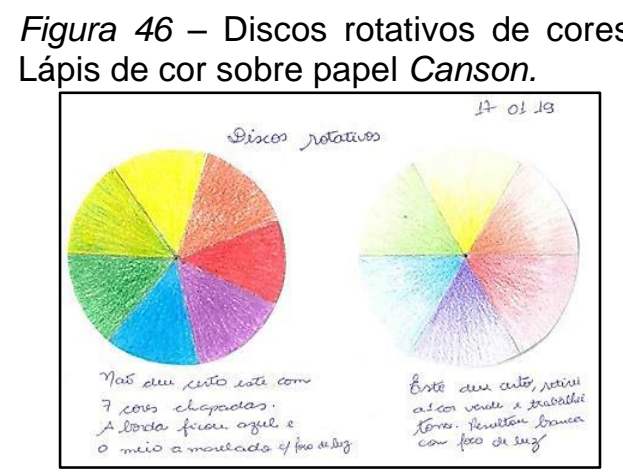

Crédito: Andrea 
No caso a seguir, a professora não explicita sua hipótese apesar de descrever as alterações que fez para visualizar a cor branca. Conclui que é necessário misturar a mesma proporção de cada cor. Indentifica e justifica o fenômeno como mistura aditiva.

Carol. [Observei] branco com a borda roxa (Fiz as cores bem fortes.)... não sei por quê (ver figuras $47 \mathrm{a}, \mathrm{b}$ ). Ao colocar a saturação das cores mais próximas ao centro e fazer as bordas mais claras, o disco ficou branco quando foi girando sob a luz do celular.

Para obter a cor branca é necessário ter a mesma quantidade de cada cor para que ao girar o disco nenhuma cor sobressaia. No disco é mistura aditiva porque está misturando luz.

Figura 47 a - Disco rotativo em repouso. Lápis de cor sobre papel Canson.

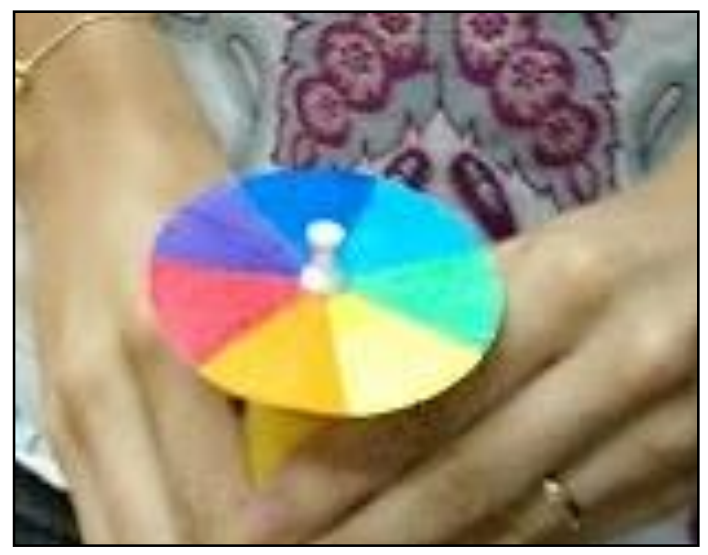

Figura $47 b$ - Disco rotativo em girando por um misturador à pilha.

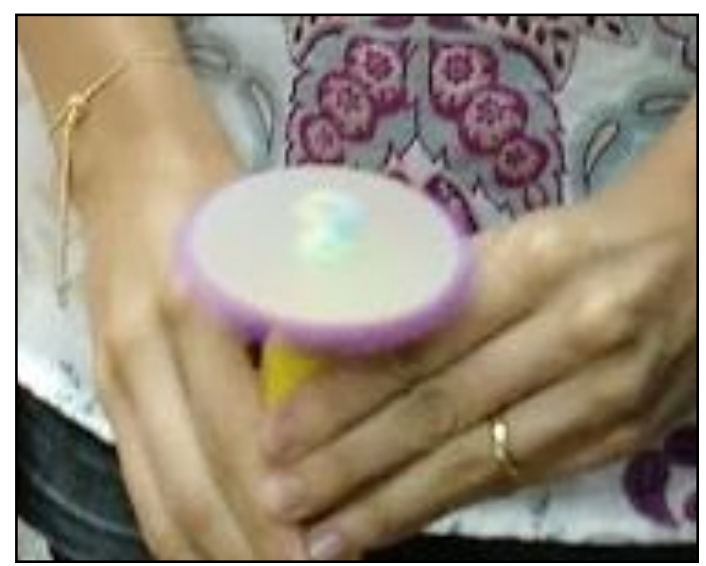

Crédito das fotos: D. Kohatsu

Esta atividade foi no penúltimo dia do curso. A professora parece perceber a especificidade da linguagem científica ao identificar a marca do lápis de cor e as cores utlizadas. Descreve os procedimentos realizados e os resultados obtidos. Tamy.

Figura 48 - Disco rotativo de Tamy com transcrição das cores observadas.

Na construção das cores do espectro utilizei as
seguintes cores dos lápis da Faber-Castell.
- Vermelho
- Laranja
- Amarelo
- Verde claro+verde folhat amarelo limão $\Rightarrow$
- verde
- Azulctaro + Azul $\Rightarrow$ azul
- Violeta $\Rightarrow$ Anil


[...]Ao girar manualmente [com um peão] observei um tom de amarelo claro. Ao girar com a "máquina" [mixer manual adaptado] ficou o centro quase branco e as laterais amarelas, ao iluminar [com a lanterna do smartphone] ficou branco no centro e amarelo claro nas bordas. Os resultados foram semelhantes ao esperado. $O$ ideal seria colorir de maneira uniforme e gradual de forma a mesclar as bordas das cores, colocando menos pressão no lápis ao colorir.

\subsection{Mistura subtrativa de cores - atividade artístico-experimental}

Nessa atividade, as professoras realizaram misturas de pigmentos com lápis de cor, tinta de impressora jato de tinta e tinta caseira. Assim como na mistura aditiva, onde há uma informação institucionalizada de que a mistura das cores forma o branco, na mistura subtrativa divulgasse que a mistura das três primárias de pigmento resulta na cor preta. Prentedíamos mostrar que o resultado da mistura é mais complexo. Esperávamos que as professoras percebessem a importância da qualidade do pigmento, a quantidade das três cores para a mistura resultar em preto, o que apareceu em algumas falas.

A maioria das professoras esperava observar a cor preta após misturar as três cores primárias pigmento (ciano, magenta e amarelo). Algumas perceberam que o lápis de cor limita a mistura das cores.

Amanda. A cor obtida é verde escuro, mas o esperado era preto. Assim, entendo que o lápis de cor interfere na obtenção da cor, pois a pintura não é uniforme.

Carol. Obtive uma cor escura. A cor esperada da mistura das três cores seria a preta. Acredito que o material utilizado não possibilitou a mistura de cores na quantidade necessária para chegar na cor preta; ou seja alguns pigmentos continuaram a refletir.

Juliana expressa isso ao conjecturar " creio que se ... utilizar um espaço menor a mistura fique preta."

Tamy relaciona com a qualidade dos pigmentos. No seu relato da mistura com tinta de impressora, demonstra a precisão do relato na linguagem científica.

Tamy. Lápis de cor. Se aproxima do resultado esperado que é o preto.

Para o resultado se aproximar mais da cor preta é necessário utilizar pigmentos puros.

Tinta de impressora. Consegui fazer a cor preta juntando em um recipiente álcool líquido 46 e um "pingo" de cada um dos pigmentos da impressora (ciano, amarelo e magenta).

Talvez por influencia da atividade com mistura aditiva, uma professora esperava visualizar branco:

Gis. Ficou um 'frutacor'. Eu esperava branco. Talvez girando ficasse branco. 
A formação de cor de uma superfície opaca pelo processo subtrativo, é um entendimento essencial no estudo da cor. Segundo a perspectiva histórico social, a linguagem pictórica vincula-se com o pensamento concreto visual, e antecede a linguagem escrita $A$ maioria das professoras utlizou um desenho com rotulagem para explicar. Nem todas se expressam com clareza.

Um exemplo acima da média apresenta um relato textual. Carol utiliza corretamente os conceitos de reflexão como reemisão da luz, e absorção. Seu desenho é coerente com o texto. Ela representa a luz incidente branca determinante da cor da luz refletida.

Figura 49- Resposta de Carol sobre formação de cores.

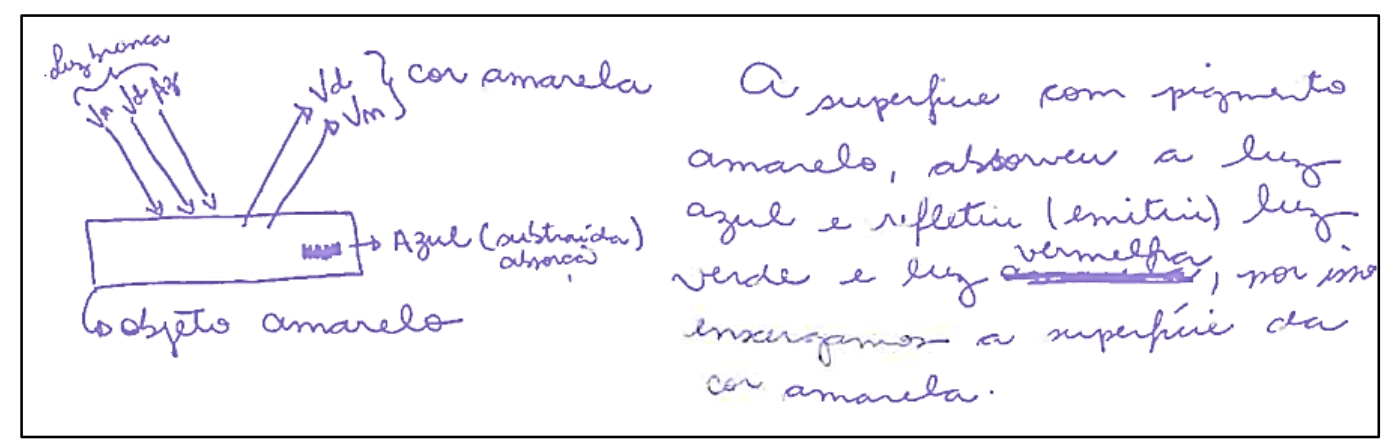

No registro de Van S, ela procura explicar através do relato textual e depois muda para um registro misto. Ela representa somente um raio refletido sem identificar a cor.

Figura 50 - Resposta de Van S sobre formação de cores.

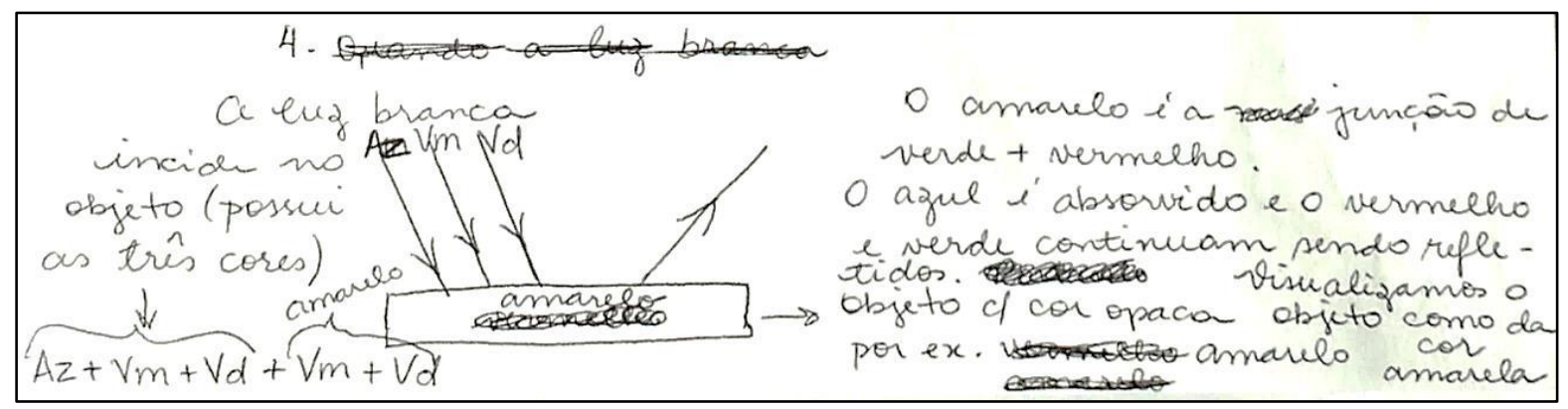

Conjecturamos que as imagens rotuladas incompletas ou confusas denotam a assimilação do conceito em processo, ou ainda, a falta de desenvolvimento de inteligência visual para comunicação, como nos desenhos abaixo. 
Figura 51 - Resposta de Ju sobre formação de cores.

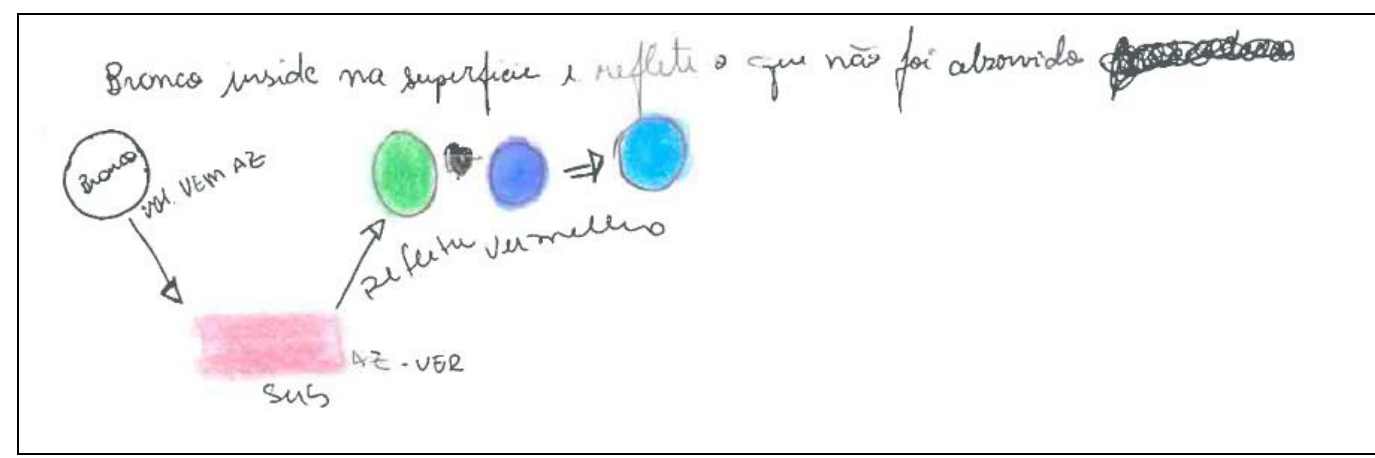

Figura 52- Resposta de Dé S. sobre formação de cores.

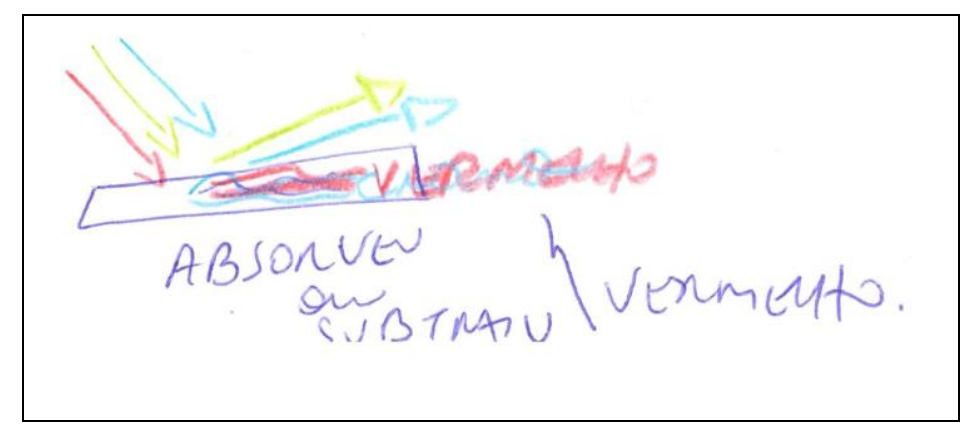

A precedência do pensamento visual sobre o verbal se evidencia na fala de Gis, onde podemos perceber também que ela não compreende a linguagem conceitual, mas sim a linguagem cotidiana e visual. Apesar de dizer que entende $o$ desenho, faltou um raio incidente para representar a luz branca.

Figura 53 - Resposta de Gis sobre formação de cores.

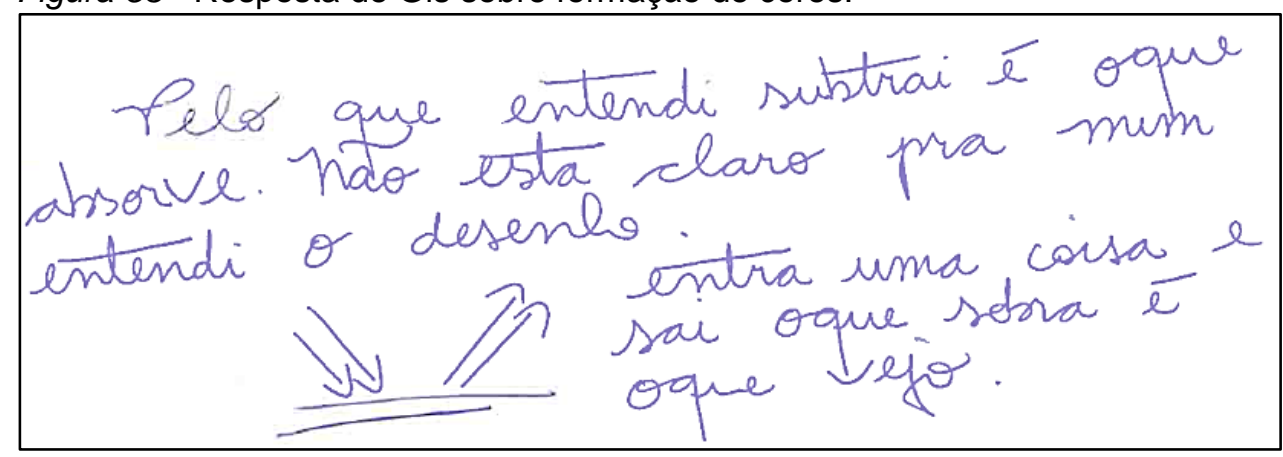

Na situação-problema proposta, nossa intenção era trazer a necessidade do registro técnico que visa a reprodutibiliade, habilidade epistêmica importante para a física, através da criação de uma pintura. A maioria das professoras não correspondeu ao que esperávamos. Entusiamaram-se com as tintas e pinturas, 
negligenciando 0 registro. Apresentamos a seguir, as professoras que desenvolveram algo similar ao esperado.

Van S. especificou a marca do lápis e a cor utilizada na mistura das cores subtrativas com lápis de cor, denotando a preocupação com a reprodutibilidade.

Figura 54 - Mistura subtrativa com lápis de cor .

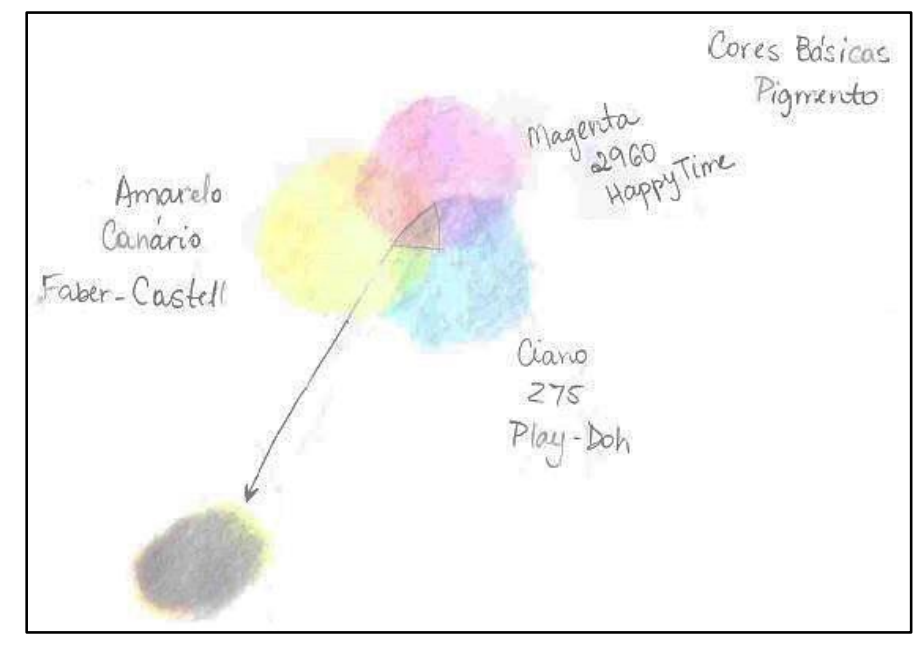

Crédito: Van S.

Elis registrou seu percurso mais artisticamente.

Figura 55 - Mistura subtrativa com lápis de cor . (a) Cores primárias. (b) Teste de cores. (c) Desenho com as cores primárias, secundárias e terciárias.

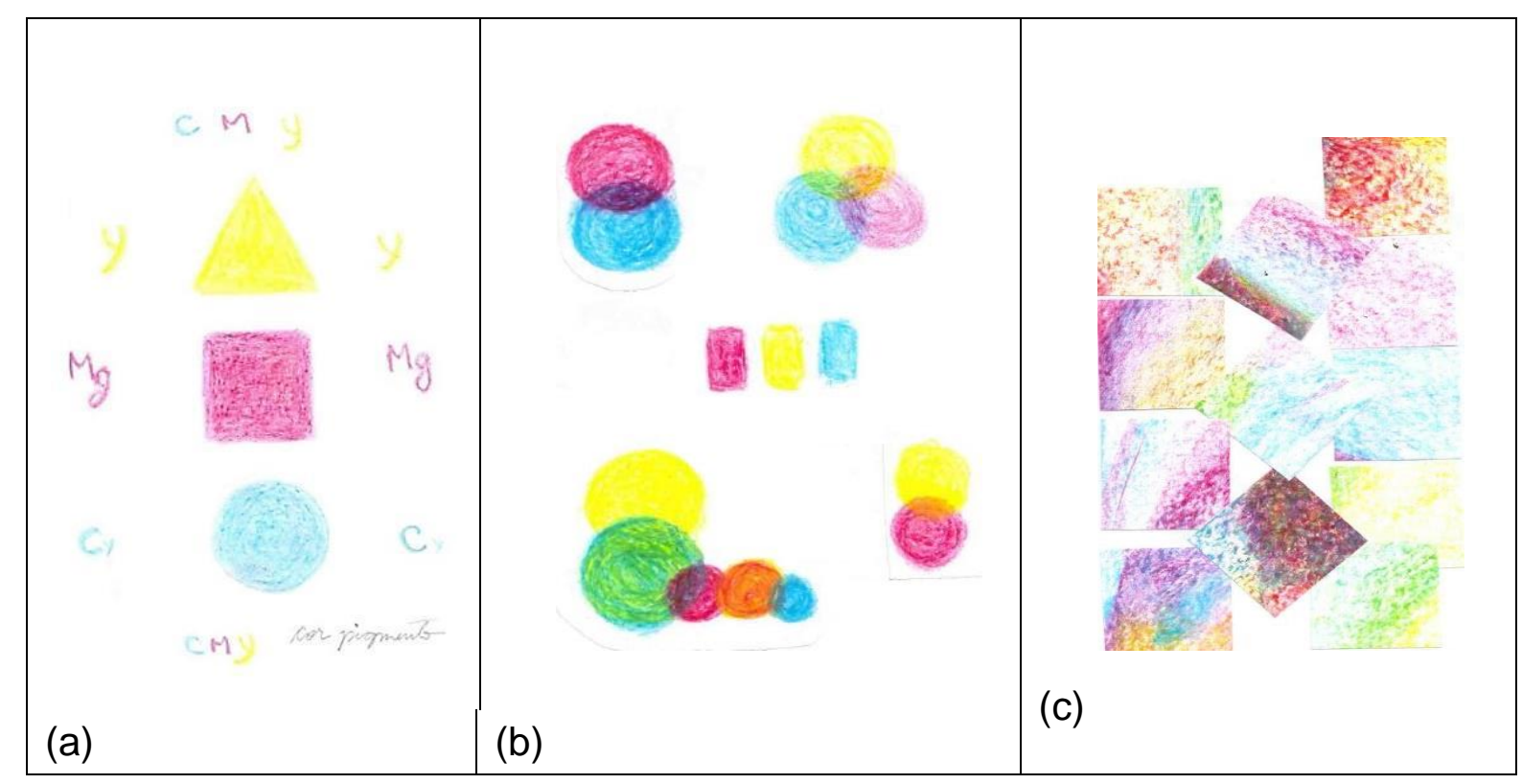

Crédito: Elis 
Tamy registrou o processo de constituição das cores desde as amostras pintadas, a formação do círculo cromático e a obra criada com as cores primárias, secundárias e terciárias. Um tipo de registro indicativo do seu pensamento, no entanto não permite uma reprodutibilidade mais precisa.

Figura 56 - Mistura subtrativa com lápis de cor . (a) Teste de cores. (b) Círculo cromático. (c) Desenho com as cores primárias, secundárias e terciárias.

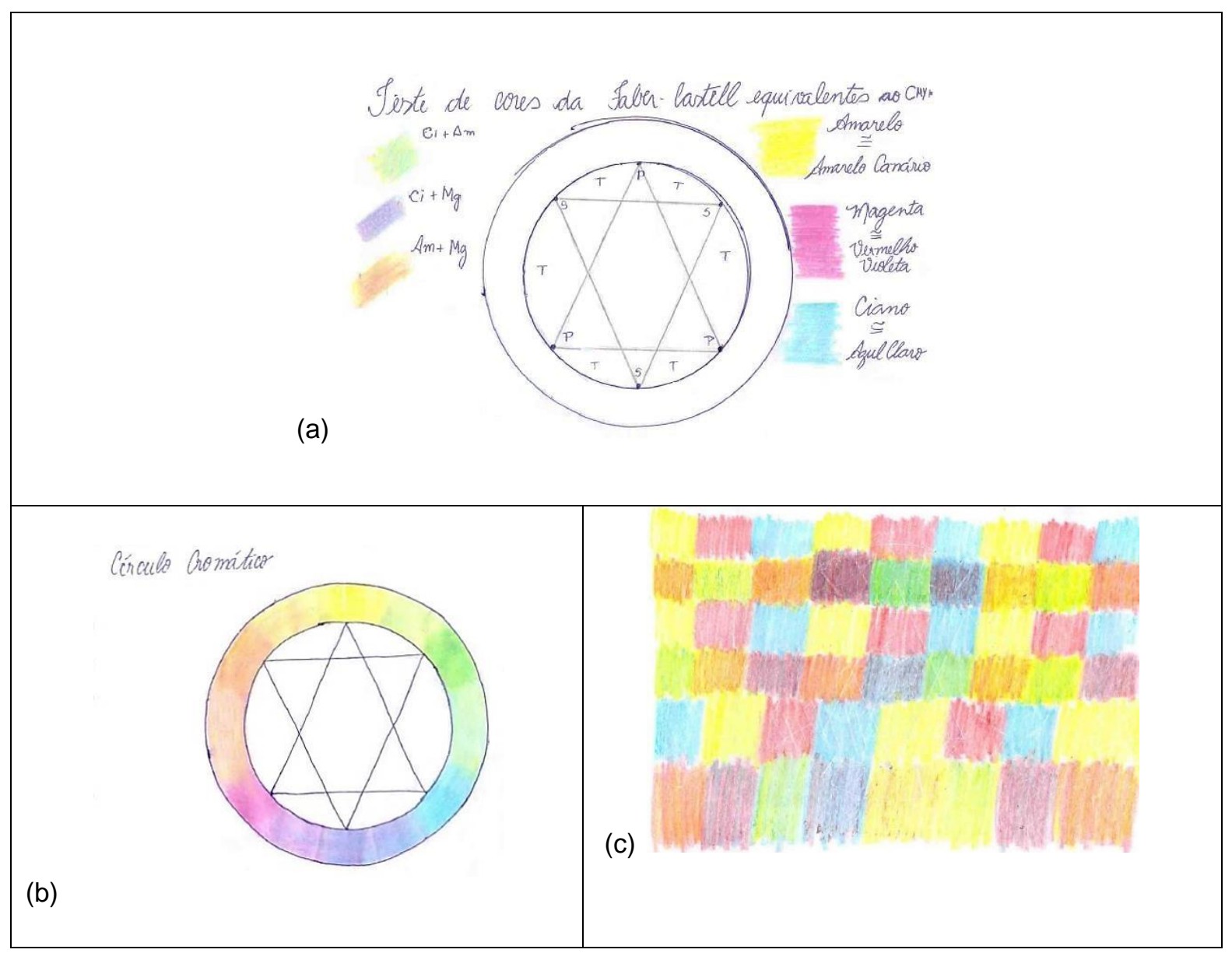

Crédito: Tamy

\subsection{Livros de Arte}

A proposta do "livro de arte" visava propiciar um veículo de narrativa artística sobre o percurso formativo no curso. Percebemos no "livro de arte" uma forma de avaliação aberta. Muitas professoras apresentaram registros dos conceitos abordados, através de linguagem pictórica rotulada ou a imagem do conceito. Mostramos na figura 31 um exemplo criativo, onde a professora ilustra as diversas formas de reflexão. A seguir vemos outras formas de apresentação do conteúdo. 
Figura 57- Imagem do "livro de arte" de Van C. sobre a interação luz-matéria.

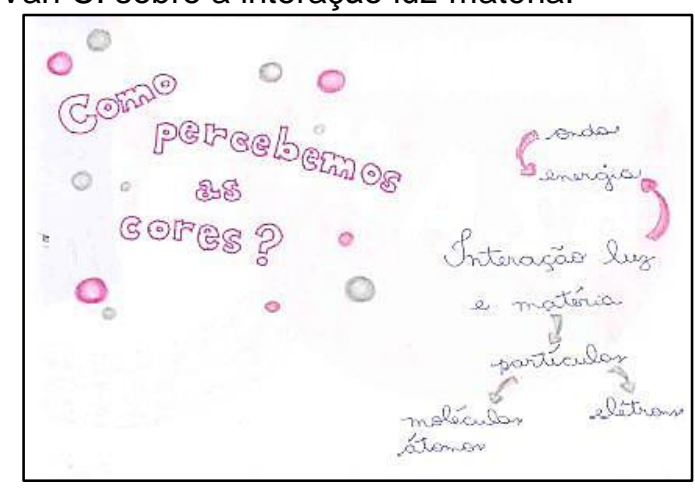

Crédito: Van C.
Figura 58 - Imagem do "livro de arte" de Carol sobre a interação luz-matéria.

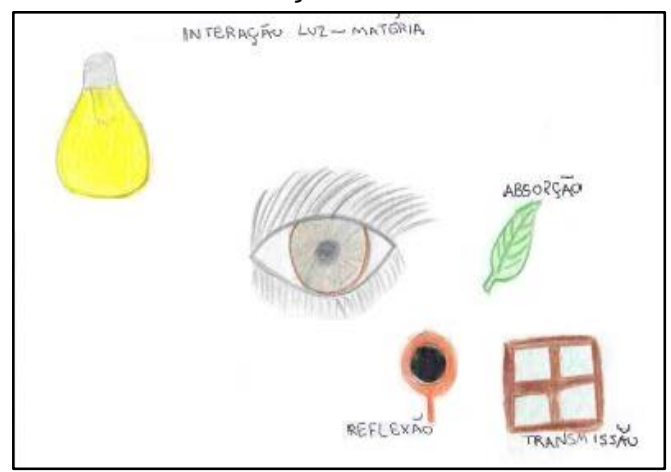

Crédito: Carol

Pela representação da figura 59 percebemos que na representação das cores no espectro da luz visível Dé $C$ pintou uma variação grande de uma cor para outra, comunicando a ideia da continuidade de tons e cores no espectro visível e não um espectro discreto de sete cores. Por outro lado, anotou as sete cores tradicionais duas vezes, ambas as figuras são de sua autoria.

Figura 59 - Excerto do "livro de arte" de Dé P. Representação do espectro eletromagnético (à esquerda) e notas de aula (à direita).

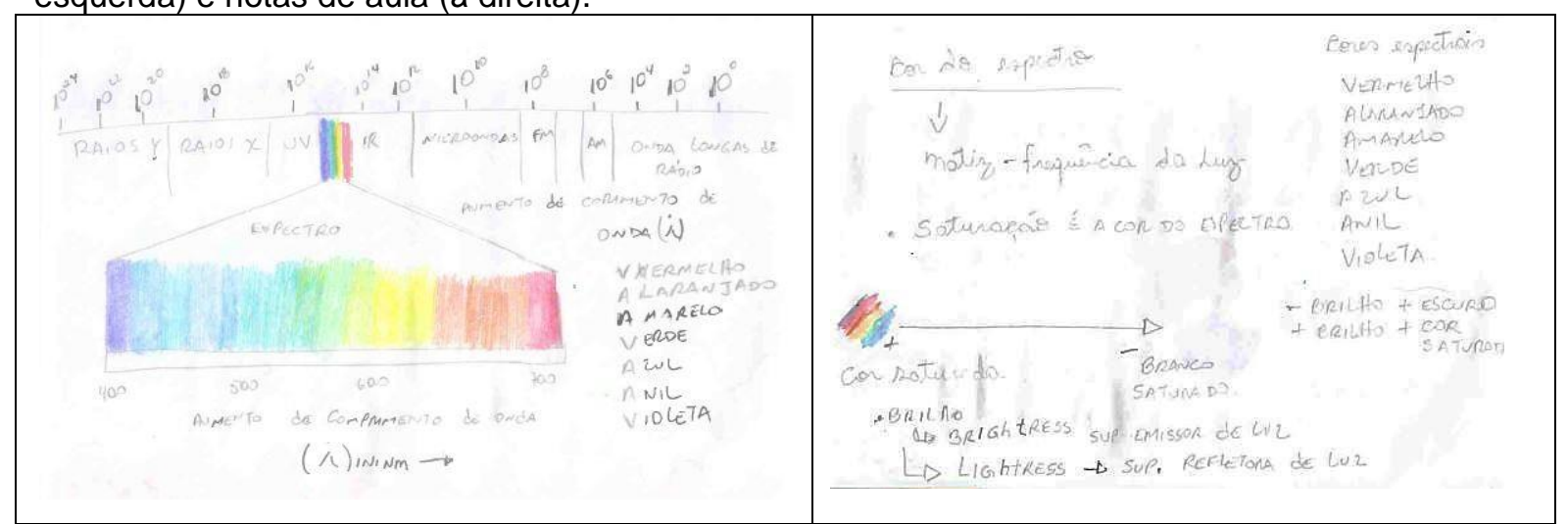

Crédito: Dé P.

A contagem de termos técnicos presentes nos "livros de arte" revelou uma gama de termos conceituais quase três vezes maior que na questão dissertativa pós curso, como vemos no gráfico 5. A comparação de termos comuns na questão dissertativa de avaliação pós curso e os termos registrados no "livro de arte", podem ser visualizados no gráfico 6 . Na tabela 5 listamos todos os termos que surgiram nas questões dissertativas pré e pós-curso e no livro de arte. A linha escura delimita os termos mencionados somente no "livro". 
Gráfico 5 - Total de termos técnicos nas avaliações pré e pós- curso e no "livro de arte" Gráfico 6 - Contagem de termos técnicos nas avaliações pré e póscurso e no "livro de arte"

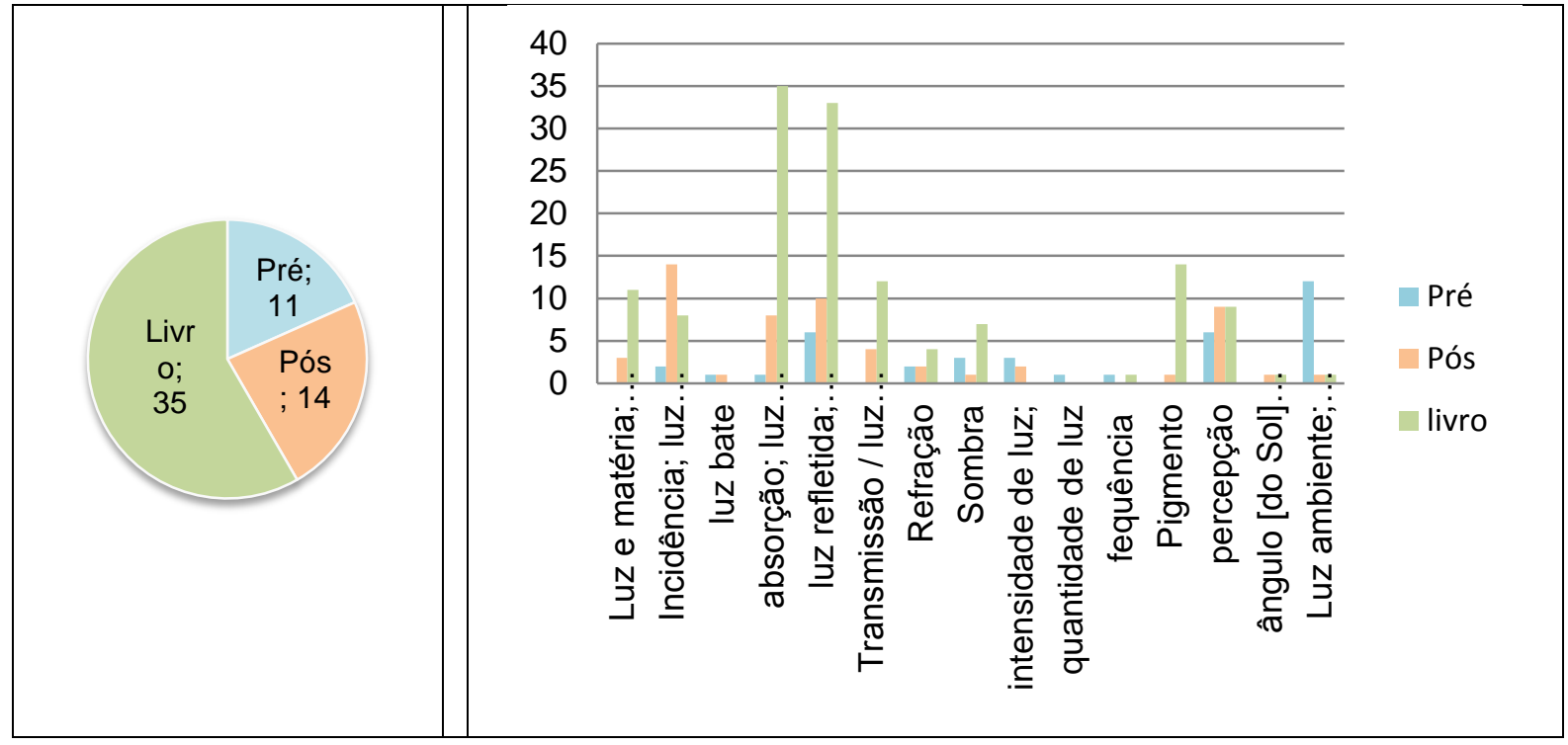




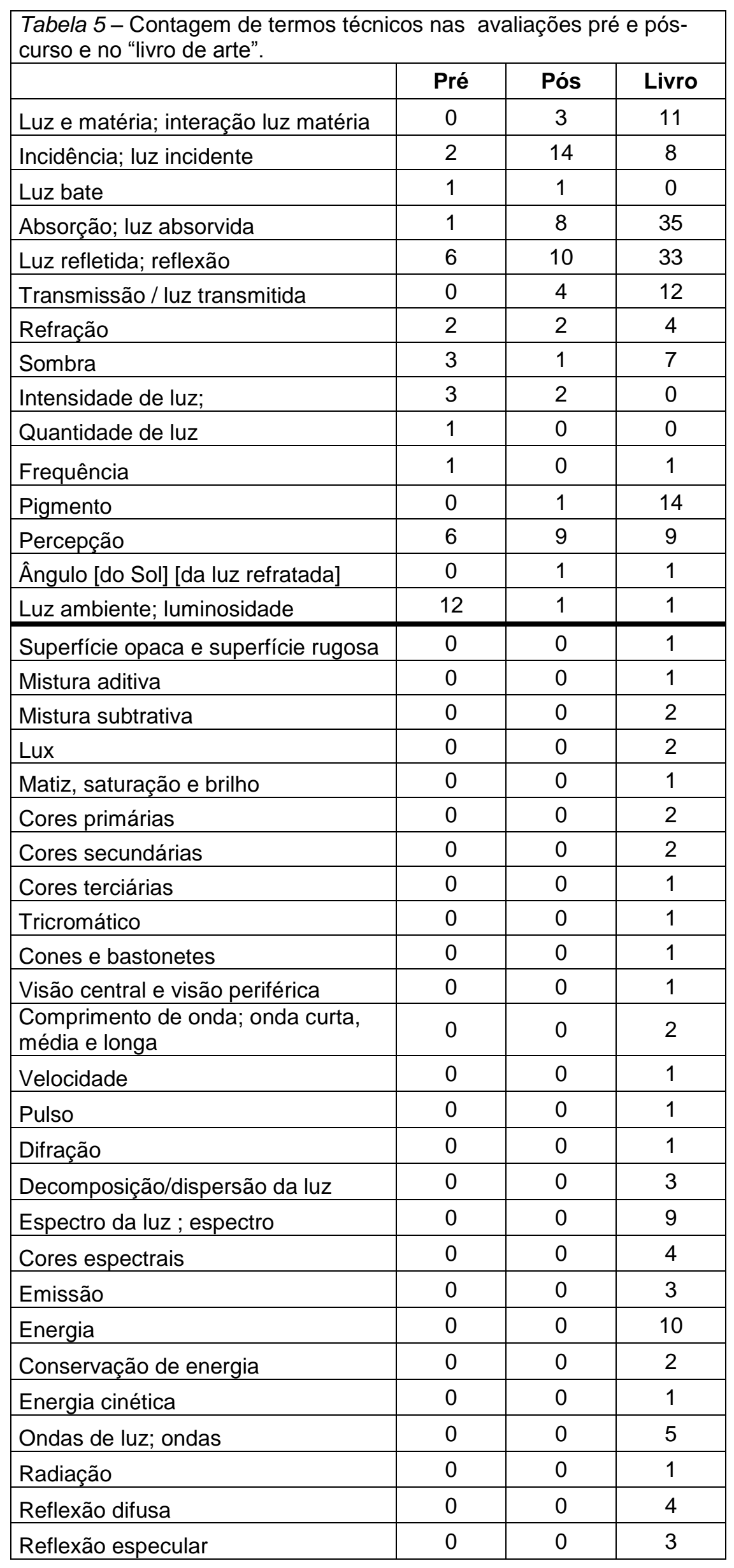


Além de encontrarem um espaço de livre expressão, a comunicação pela linguagem pictórica ou esquemas ou desenhos rotulados exprimem a memória visual vinculada ao pensamento concreto.

"Os processos de percepção visual e da linguagem são de natureza opostos. A percepção visual é integral, os elementos são reunidos pelo campo visual. A fala é analítica, os elementos são estruturados numa sentença num processamento sequencial (VIGOTSKI, 1988, p. 37).

O desenho como forma de expressão é mais fácil que a escrita. Tanto na filogênese como na ontogênese a linguagem pictórica antecede a escrita, o pensamento verbal evolui do pensamento concreto visual.

O "livro de arte" possibilita avaliar a habilidade de organização, comunicação visual e erros conceituais (figuras 38 e 62). Na figura 60 temos um bom exemplo de comunicação visual. A imagem representa o fenômeno real. Na figura 61, Amanda para representar a mistura aditiva realizou o mesmo processo para mistura subtrativa com lápis de cor, deixando-nos em dúvida se compreendeu que a mistura de lápis de cor só vale para o processo subtrativo.

Figura 60 - A imagem representa a realidade.

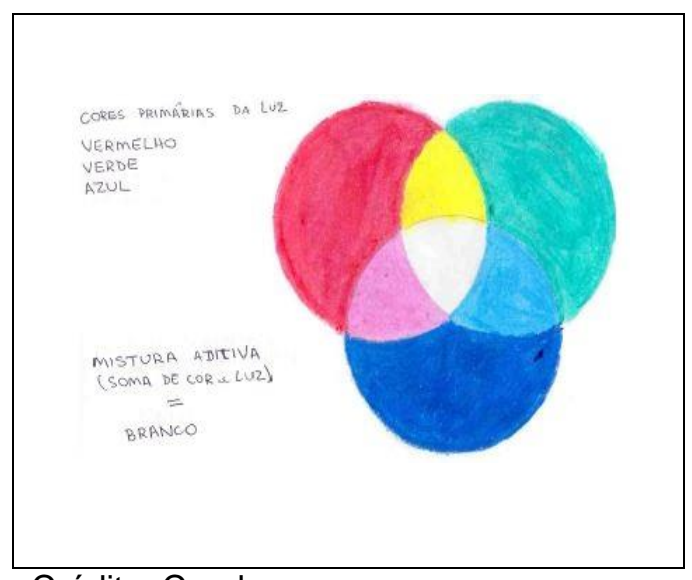

Crédito: Carol
Figura 61- A rotulagem e a imagem são incoenrentes.

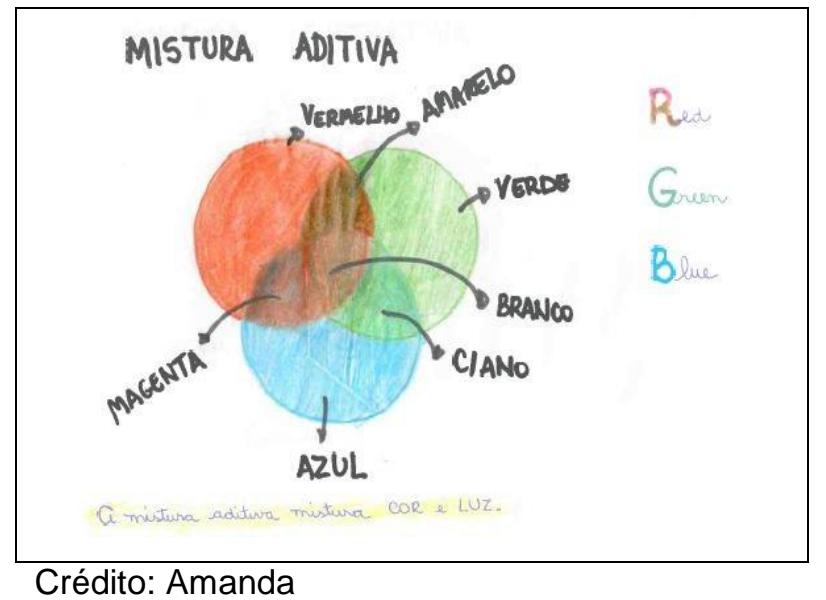

$\mathrm{Na}$ figura 39, Tamy representa a imagem de um experimento demonstrativo onde colocamos $10 \mathrm{~mL}$ de soluções de tinta de impressora jato de tina diluídas em $50 \mathrm{~mL}$ de água dentro de copos transparentes em cima de um retroprojetor. Após alguns minutos medimos as temperaturas e verificamos que a cor preta estava com a temperatura acima da temperatura das soluções de outras cores. Concluimos que a luz absorvida se transforma em calor. Quando Tamy identifica a luz lateral como 
refletida, ao invés de transmitida, julgou pela aparência (um exemplo de pseudoconceito).

Figura 62 - Um exemplo de pseudoconceito. a solução semitransparente amarela transmite a luz por cima e lateralmente também, porém a professora escreveu luz "refletida".

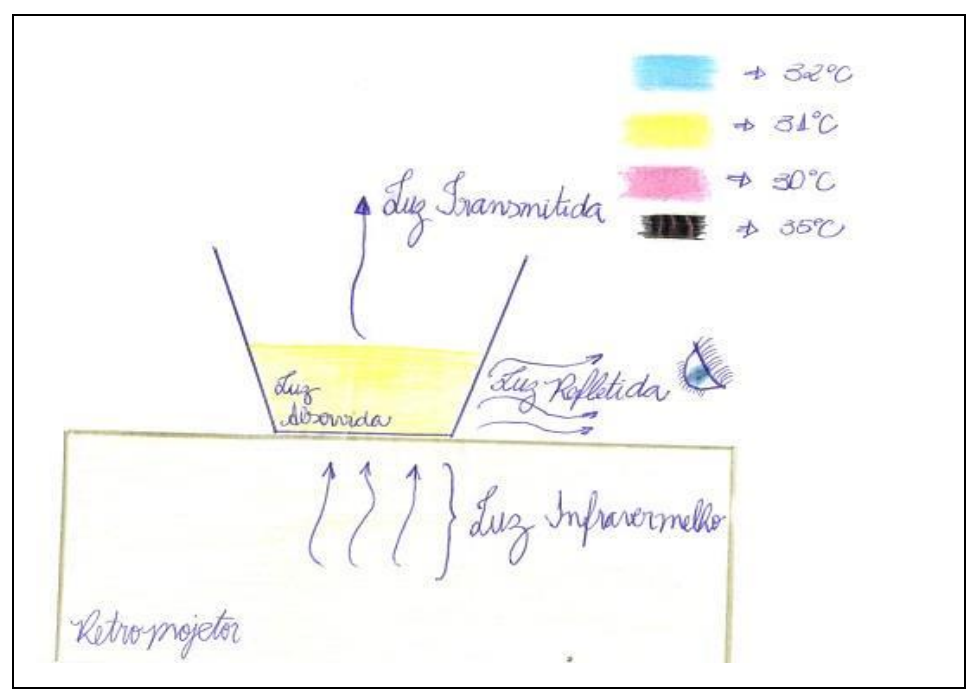

Crédito: Tamy

Conhecer a memória afetiva, como nos depoimentos a seguir (figuras 63 a $65)$.

Figura 63 - Abertura do "livro de arte" de Ju.

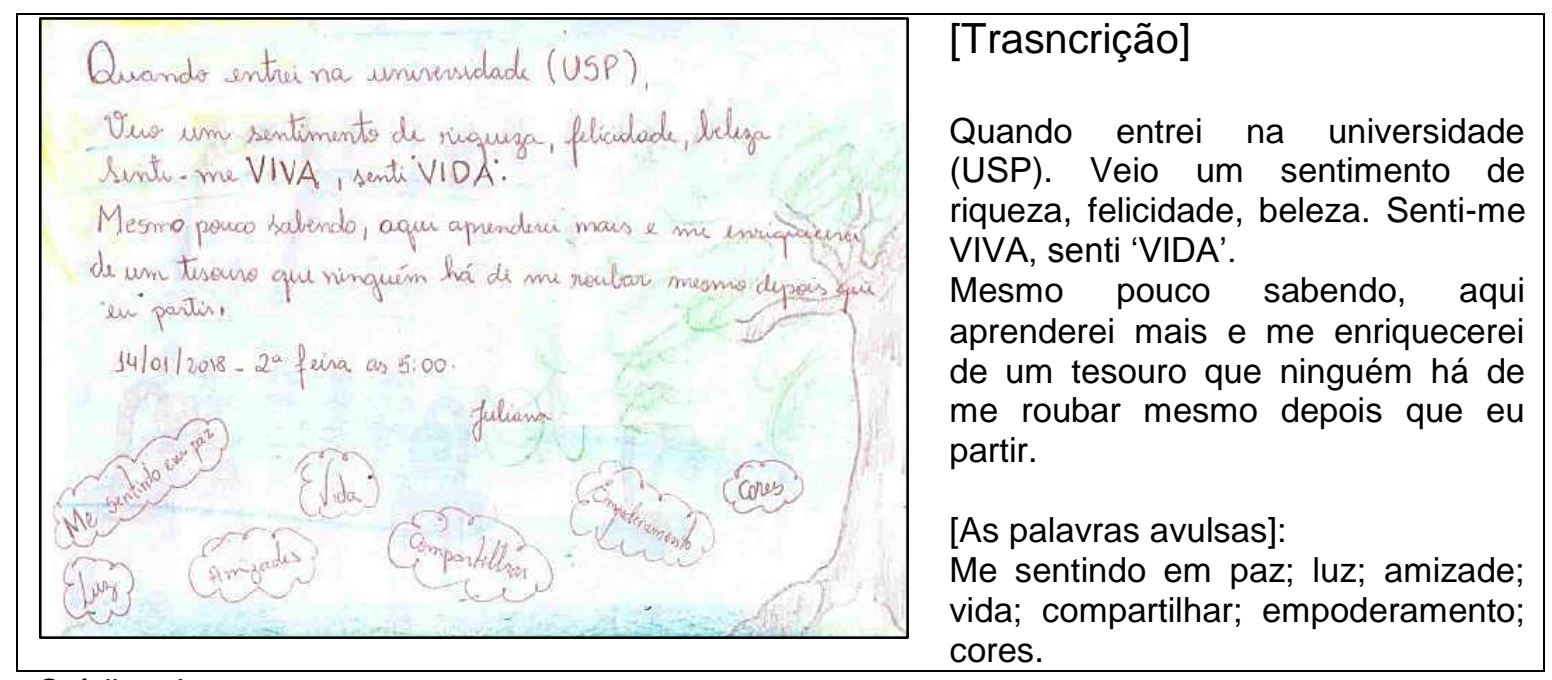

Crédito: Ju 
Figura 64- Depoimento sobre a visita ao MASP extraído do "livro de arte" de Ju.

\begin{tabular}{|c|c|}
\hline 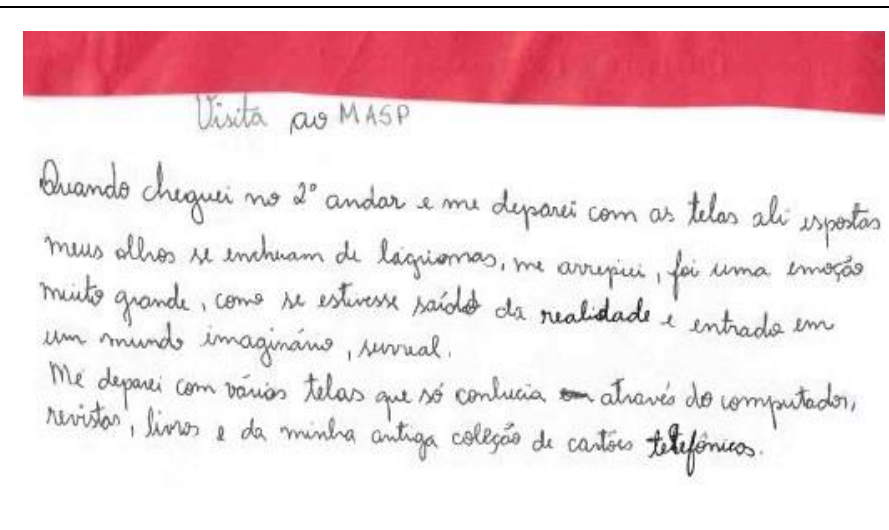 & $\begin{array}{l}\text { Quando cheguei no } 2^{\circ} \text { andar e me } \\
\text { deparei com as telas ali espostas } \\
\text { [sic] meus olhos se encheram de } \\
\text { lágrimas, me arepiei, foi uma } \\
\text { emoção muito grande, como se } \\
\text { estivesse saído da realidade e } \\
\text { entrado em um mundo imaginário, } \\
\text { surreal. } \\
\text { Me deparei com várias telas que só } \\
\text { conhecia através do computador, } \\
\text { revistas, livros e da minha antiga } \\
\text { colecãa de cartões telefônicos. [...] }\end{array}$ \\
\hline
\end{tabular}

Crédito: Ju

Figura 65 - Experiência sobre a visita ao MASP extraído do "livro de arte" de Tamy.

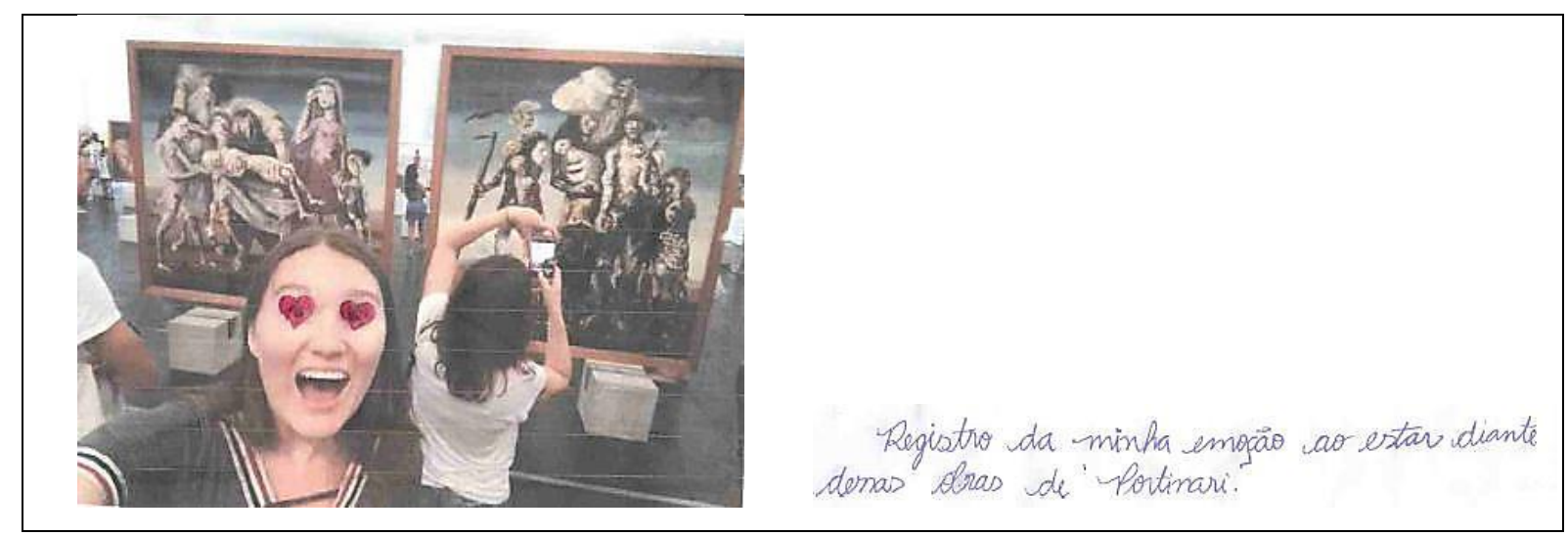

Crédito: Tamy

Já transcrevemos algumas passagens desta professora que fez do "livro de arte" um "diário de bordo". Algumas expressões de aprendizagem.

16.01.19 - (...) Utilizar o app RGB, causou confusão em meus entendimentos por sempre utilizar, desde a formação em Artes Visuais, as cores $1^{\text {as }}$ pigmento.

17.01.19 - DISCOS ROTATIVOS: Tive que pedir explicações para a prof ${ }^{a}$ Dóris para compreender melhor e perceber que tenho que desconstruir o que sei para construir e assimilar melhor este tema/conteúdo/atividade/prática. [Refere-se às cores primárias de luz.]

Outras professoras de Artes falaram sobre isto, o conflito gerado por descobrirem as cores primárias de luz, diferentes das cores primárias de pigmentos.

Gis listou no final do "livro" o que aprendeu no curso citando conteúdos, atividades, exemplos dados durante o curso, aplicativos e destacamos o trecho onde que nos parece a integração de Arte e Ciência. 
Figura 66- Depoimento sobre o que aprendeu no curso. Extraído do "livro de arte" de Gis.

\begin{tabular}{|c|c|}
\hline $\begin{array}{l}\rightarrow \text { Wue num trabalho } \\
\text { de artes visuais nas } \\
\text { s= as cores mas se } \\
\text { elas refteirm, transpassam } \\
\text { ou abrorvem a cor ? } \\
\text { uma passibilidade de express } \\
\text { para of artista. }\end{array}$ & $\begin{array}{l}\text { [Trasncrição] } \\
\text { O que levo deste curso? } \\
\text { [...] Que num trabalho de artes } \\
\text { visuais não só as cores mas se elas } \\
\text { refletem, transpassam ou absorvem } \\
\text { a cor é uma possibilidade de } \\
\text { expressão para o artista. }\end{array}$ \\
\hline
\end{tabular}

Uma de nossas expectativas ao propor a produção do "livro de arte" como síntese do percurso ao longo de curso era a expressão criativa através de obras visuais. Ao longo desta seção apresentamos algumas, exemplificando a comunicação da aplicação do conceito. Percebemos, no entanto, que algumas professoras apresentaram poucas obras criativas. Conjecturamos como causas a pouca disponibilidade de tempo, falta de material, principalmente para as professoas que moravam fora da cidade de São Paulo, e talvez tenha a causa seja o que Vigotski chama de "suplício da criação". "Criar é difícil. A necessidade de criar nem sempre coincide com as possibilidades de criação e disso surge um sentimento de sofrimento penoso de que a ideia não foi para a palavra [...] (VIGOTSKI, 2009, p.55). 


\section{CONCLUSÃO}

Qual o potencial da apredizagem de Física na disciplina de Artes? A partir de nossa análise, concluimos que potencialmente pode-se desenvolver conhecimento conceitual e epistêmico de Física na disciplina de Artes no ensino fundamental. A cor permitiu-nos avaliarmos a aprendizagem potencial dos conceitos de interação luz matéria (reflexão, transmissão e absorção), espectro da luz branca, processo aditivo e substrativo de formação de cores. Pela contagem de termos concluímos que houve enriquecimento do vocabuláio, um indicativo de aprendizagem. "A riqueza do vocabulário e das formas da fala atestam a riqueza de pensamento, e o estudo do próprio pensamento reduz-se ao estudo dos hábitos de fala característicos de uma dada pessoa" (LURIA, 1996, p.207). A ausência de justificativa dos testes nos impossibilitou de avaliar se as professoras sabem explicar o conceito. A análise das respostas dissertativas do questionário pós curso e dos roteiros indica um predomínio de respostas com palavras avulsas ou associadas em listas, denotando uma lógica associativa. Isto pode indicar o desenvolvimento limitado ao pensamento por complexo, vinculado ao pensamento concreto, ou à dificuldade intrínseca de escrever, a tradução da linguagem interior para a exterior e lou `a dificuldade de explicação do conceito. Segundo a perspectiva histórico-cultural, atuamos na zona de desenvolvimento imediato. O aprendizado se desenvolve de acordo com o tempo de maturação e ações do indivíduo. "Os significados das palavras evoluem. Quando uma palavra nova, ligado a um determinado significado, é apreendida pela criança, o seu desenvolvimento está apenas começando [...]" (VIGOTSKI, 2009, p.246).

Do ponto de vista educacional, consideramos o desenvolvimento de habilidades epistêmicas mais importantes que os conceituais. Procuramos introduzir o mínimo de termos específicos e possibilitar a vivência prática com os conceitos através de atividades artísticas e experimentais. Através das respostas analisadas dos roteiros de experiências, consideramos possível desenvolver observação, percepção, medição, identificação variáveis, levantamento e verificação de hipóteses, explicação, comunicação-se pela voz e pela escrita, criação.

Das atividades oferecidas, todas nos pareceram viáveis. A confecção do "livro de arte" pareceu-nos um instrumento interessante de síntese do conhecimento, de criações artísticas e de expressão livre. Em geral, os intrumentos de avaliação visam 
o aspecto cognitivo. O "livro de arte" enquanto instrumento aberto de avaliação permitiu-nos conhecer outros aspectos de impacto do curso. Talvez a experiência do MASP ou de estar no USP-Escola tenha colaborado mais para o desenvolvimento integral humano que o conhecimento de física da cor.

Nas atividades com mistura subtrativa, a sistematização do registro não se concretizou plenamente. As professoras se envolvem com o processo de criação, experimentam as misturas de cores nas suas palhetas sem uma preocupação na reprodutibilidade daquela cor, atitude que pensamos ser "científica". Conjecturamos que o processo de investigação artístico possa ter premissas distintas da investigação científica. A BNCC propõe o ensino investigativo em todas as disciplinas. Podemos aplicar os pressupostos investigativos da Ciência na Arte?

A visita ao acervo permanente do MASP merece protagonismo. O tempo reduzido no USP-Escola em relação à quantidade de conteúdo e atividades desejadas, gera-nos dúvida sobre a inserção da visita ao MASP. Depois de escutarmos as experiências das cursantes, percebemos a riqueza em estar diante de uma obra de arte. Ver uma obra de arte ao vivo proporciona um mobilização interna intensa. Nas palavras de uma professora do curso "Arte que emociona, encanta, conecta, transcende". Há também um indicativo da necessidade da "obrigatoriedade" da visita ao museu, a educação não-formal como elemento da formação humana. No curso anterior, de onze docentes cursantes, somente a professora de física conhecia o acervo permanente do MASP. Neste curso, de um total de 24 docentes, três disseram que estavam indo pela primeira vez ao MASP mas suspeitamos que havia mais professoras nesta condição.

Recursos tecnológicos sob a forma de aplicativos, simuladores virtuais, vídeos e outros foram coadjuvantes por falta de tempo. Há uma grande diversidade de aplicativos relativos à cor e luz gratuitos a serem explorados. 


\section{CONSIDERAÇÕES FINAIS E PERSPECTIVAS FUTURAS}

Este projeto abordou aspectos físicos básicos sobre cor pensando sua aplicação no ensino fundamental, na disciplina de Arte. Numa proposta para o curso de Física do ensino médio, seria necessário aprofundar os conceitos de óptica como refração, interferência, difração, espalhamento; introduzir conceitos de física quântica ao abordar a produção da luz-cor; incluir história e filosofia da ciência; integrar conceitos de química e de biologia.

Vemos um grande potencial de introduzir conceitos e procedimentos da física na disciplina de Artes. Na arte óptica, conceitos de óptica geométrica, física, e quântica. Na arte cinética, há artistas que exploram conceitos de som e ondas, mecânica. A abordagem de física em artes pode ser mais atraente por haver menos formalidade conceitual e proporcionar certa ludicidade com as atividades científicas. Considerando ainda que há uma grande evasão no ensino médio e a nova BNCC para o ensino médio diminui as possibilidades da educação científica através da física, introduzir física na disciplina de Arte no ensino fundamental adquire maior importância para proporcionar a educação científica.

Avaliamos nossa sequência de ensino-aprendizagem com professoras de Arte do ensino fundamental e médio. Para uma avaliação efetiva do impacto na Educação, necessita-se investigar como as professoras cursantes se apropriam e transmitem o conteúdo desenvolvido no curso? Qual o aprendizado do aluno? Ele se reflete no aprendizado de Física?

Havia cinco professoras de educação infantil no nosso curso. Há uma carência de cursos de formação científica direcionado para a educação infantil. A realização de experimentos lúdicos relativos a cor e a atração natural pelo tema tornam o ensino da cor uma porta de entrada para a educação científica na primeira infância. O que e como desenvolver o conhecimento da física?

O tema cor é complexo por ser multidisciplinar. Considerando somente a área da Física "dura", percebemos que há conhecimentos específicos que não são abordados na graduação em Física, e não encontramos nenhum livro em português específico. No ensino médio, o modelo de visão de cores restringe-se ao sistema tricromático. A física moderna deveria incluir também modelos mais atuais de formação de cores e de visão de cores, como o modelo retinex que inclui o sistema neurovisual e envolve interdisciplinaridade com neurociência. Na área de História e 
Filosofia da Ciência também há um vasto campo, facilitado pela maior quantidade de textos de fonte primária traduzidos para o português. Nossa intenção inicial era integrar tópicos de história e filosofia da ciência e da história da arte. Nosso sentimento é que olhamos a ponta do iceberg, a dimensão mais profunda está ainda por ser desbravada. O Conhecimento se desenvolve indivisível. O paradigma educacional vigente o fragmenta. Como proporcionar uma formação integrada na educação básica, na formação inicial e na formação continuada? Imaginando cada saber como uma fruta, a integração dos saberes é uma salada de frutas ou uma vitamina (shake)? Como a formação integrada afeta a compreensão/percepção da realidade do indivíduo?

Há dois momentos nos dois cursos ministrados no USP-Escola que nos chamou a atenção: a visita ao acervo permanente do MASP e os momentos de criação artística. A experiência da visita ao MASP parece evocar fascinação, emoção, transcendência. Além do MASP, a cidade de São Paulo possui outros museus, centros culturais, e frequentemente há exposições de arte que podem ser explorados como mediadores culturais de ensino-aprendizagem de física. Segundo a perspectiva histórico-cultural, a consciência do indivíduo se desenvolve de fora para dentro. $\mathrm{O}$ ambiente sociocultural é fator determinante dos processos afetivos, volitivos e cognitivos individuais. Como a formação cultural ampla do indivíduo influência no aprendizado e/ou visão da Física?

Durante as atividades criativas as pessoas parecem mais descontraídas enquanto trabalham concentradas. O "livro de arte" enquanto instrumento aberto de avaliação permitiu-nos conhecer outros aspectos de impacto do curso. Pensamos que uma visão integrada de educação implica ir além de mesclar conteúdos e procedimentos. Como canalizar as manifestações afetivas, criativas, estéticas para a educação científica em física?

O potencial de ensino-aprendizagem de física em artes, na educação infantil, a integração de artes e história da ciência no curso de física do ensino básico, na graduação, e repensar a forma e critérios de avaliação visam a melhoria da educação intencionando a dissolução das fronteiras do conhecimento disciplinar, entre afeto e cognição. Todas estas questões são temas importantes para futuras pesquisas e /ou elaboração de artigos para revistas de ensino de ciências em geral, como produtos desta pesquisa. 


\section{REFERÊNCIAS}

${ }^{*}$ Modelo ISO 690

ALBERS, J. A interação da cor. Trad. J.L. Camargo. 1ª. edição 2009, 2ª tiragem 2016. São Paulo: WMF Martins Fontes, 2009.

ARDILA, A. L.S. Vygotsky in the 21st century. Psychology in Russia: State of the Art . Volume 9, Issue 4, 2016.

ARNHEIM, R. Arte e percepção visual. Uma psicologia da visão criadora. Trad. I.T. de Faria. 4a. ed. São Paulo: Livraria Pioneira Editora, 1988.

BERLIN, B.,KAY,P. Basic Color Terms, Berkeley: University of California Press, 1969.

BOMFORD, D. The history of colour in Art. In LAMB, T.; BOURRIAU, J. (eds) Colour Art \& Science. Cambrige: Cambridge University Press, 1995. p. 7-30

BRASIL. MEC/CONSED/UNDIME. Base Nacional Comum Curricular (BNCC). Educação é a Base. Brasília, 2017. Disponível em $<$ http://basenacionalcomum.mec.gov.br/images/BNCC publicacao.pdf $>$. Acesso em: 02.06.2018.

BRITO, N. B. de. ;REIS, J.C. As relações entre a Ciência e a Arte no século XIX e o conceito de cor. In III Conferencia Latinoamericana del International, History and Philosophy of Science. Teaching Group IHPST - LA 2014. Santiago de Chile, 17- 19 de Noviembre. p. 21. Disponível em <http://laboratoriogrecia.cl/wpcontent/uploads/2015/11/P21-BARBOZA-REIS1.pdf > . Acesso em 12.09.2017

CASTORINA, J.A., FERREIRO, E., LERNER, D. OLIVEIRA, M.K. Piaget-Vygotsky. Novas contribuições para o debate. 6ª ed. São Paulo: Ática, 2010.

DELORS, Jacques et alli. Educação: um tesouro a descobrir; relatório para a UNESCO da Comissão Internacional sobre Educação para o século XXI. 7.ed. rev., Brasília: UNESCO; São Paulo: Cortez Editora, 2012.

DUSCHL, R. Science education in three-part harmony: balancing conceptual, epistemic, and social learning goals, Review of Research in Education, 32, 268-291.

FEITOSA-SANTANA, Claudia et al. Espaço de cores. Psicologia USP [online]. 2006, vol.17, n.4 pp.35-62 [acesso em 26.06.2018]. Disponível em http://www.scielo.br/scielo.php?script=sci arttext\&pid=S0103$65642006000400003 \& \operatorname{lng}=e n \& n r m=i s o$.

FEYMANN, R. LEIGHTON, R., SANDS, M. Lições de Física de Feynman: edição definitiva. v. 1 e 2. Porto Alegre: Bookman, 2008.

FLETCHER, R., VOKE, J. Defective Colour Vision. Bristol: Adam Hilger Ltd, 1985. 
GAGE, J. A cor na arte. Trad. J.L. Camargo. São Paulo: WMF Martins Fontes, 2012. (Coleção mundo da arte)

GASPAR, A. Atividades experimentais no ensino de física: uma nova visão baseada na teoria de Vigotski. 1ㄹ. Ed. - São Paulo: Editora Livraria da Física, 2014.

GIBSON, J.J.The perception of the visual world. Cambridge: The Riversaide Press, 1950, p.12, 166-69.

GOETHE, J.W. Doutrina das cores. Tradução, apresentação e comentários de Marco Gianotti. São Paulo: Nova Alexandria. 1a. edição impressa, 1993. Edição do Kindle, 2018.

HARDIN, C.L. Berlin and Kay Theory. Encyclopedia of Color Science and Technology. New York: Springer Science+Business Media, 2013 [acesso em 10.07.18]. Disponível em http://imbs.uci.edu/ kjameson/ECST/Hardin BerlinKayTheory.pdf

HEESEN, R. The Young-(Helmholtz)-Maxwell. Theory of Color Vision. [Preprint] , 2015. Disponível em <http://philsci-archive.pitt.edu/id/eprint/11279>. Acesso em 13.01.2018

HOAUISS, A. Grande dicionário Hoauiss. Disponível em $<$ https://houaiss.uol.com.br/pub/apps/www/v3-3/html/index.php\#0>. Acesso em 27.07.2018.

LA TAILLE, Y., OLIVEIRA, M.K., DANTAS, H. Piaget, Vygotsky, Wallon - Teorias psicogenéticas em discussão. São Paulo, Summus, 1992.

JONES, L.A. (chairman). Committee on colorimetry. Optical Society of America. The Science of Color. New York: Thomas C. Y. Crowell Company, 1953. p.34, 220-53.

KIRWIN, G. Operation Primary Physical Science: Light and Color . Workshop leader's guide. Department of Physics and Astronomy- Louisiana State University, $2000 . \quad$ Disponível em $<$ https://www.compadre.org/precollege/document/ServeFile.cfm?ID=2504\&DoclD=26 \#Doc26 >. Acesso em 24.11.2017.

KIRWIN, Gayle. Operation Primary Physical Science: Nature of Light. Workshop leader's guide and participants guide. Department of Physics and AstronomyLouisiana State University, 2000. Disponível em <https://www.compadre.org/Repository/document/ServeFile.cfm?ID=2508\&DoclD=37 >. Acesso em 24.11.2017.

KOZULIN, A. et al, editors. Vygotsky's Educational Theory in Cultural Context. Cambridge: Cambridge University Press, 2003.

LIVINGSTONE, M.. Vision and art. The Biology of seeing. Abrams, New York, 2014.

LONGAIR, M. Light and colour. In LAMB, T.; BOURRIAU, J. (eds) Colour Art \&

Science. Cambrige: Cambridge University Press, 1995. p. 65-102. 
LURIA, A.R. Desenvolvimento cognitivo.

Trad. F. L. Gurgueira. 8ª ed. São Paulo, Ícone, 2017.

MARTINS, Simone R.; IMBROISI, Margaret H. Impressionismo. [Acesso em 21 março 2018] Disponível em: http://www.historiadasartes.com/nomundo/arte-seculo19/impressionismo/.

MOREIRA, M.A. Metodologias de Pesquisa em Ensino. São Paulo, Editora Livraria da Física, 2011.

MEYER, P. O olho e o cérebro: biofisiologia da percepção visual. Tradução Roberto L. Ferreira. Edição original 1997. São Paulo: Editora UNESP, 2002.

NASSAU, K. The Physics and Chemistry of Color : the fifteen causes of color. New York: Wiley-Interscience, 1983.

NEW ENGLAND BOARD OF HIGHER EDUCATION. Explorations in Optics. Photon projects. Boston, 2013. Disponível em $<$ http://www.nebhe.org/info/pdf/stempbl/ExplorationsinOpticsJuly2013.pdf >. Acesso em 24.11.2017.

NEWTON, Isaac, Sir. Óptica. Tradução, introdução e notas de A. K. T. Assis - São Paulo: Editora da Universidade de São Paulo, 1996.

OSA, The Optical Society. Black is Black - Or is it?. Optics 4 kids. Disponível em $<$ https://www.optics4kids.org/classroom-activities/5-10/black-is-black-\%E2\%80\%94or-is-it >. Acesso em 24.11.2017.

OSA, The Optical Society . Spinning Your (Color) Wheels. Optics 4 kids. Disponível em <https://www.optics4kids.org/classroom-activities/5-10/spinning-your-(color)wheels >. Acesso em 24.11.2017.

OVERHEIM, R.D. WAGNER, D.L. Light and Color. New York: John Wiley \& Sons, Inc., 1982.

PARKHURST, C.; FELLER, R. Who invented the color wheel?. Color Research and Application, 7, 1982; p. 217-230.

PEREIRA, J.C.R. Análise de dados qualitativos. Estratégias metodológicas para as Ciências da Saúde, Humanas e Sociais. $3^{\underline{a}}$ ed. $1^{\underline{a}}$ reimp. São Paulo: EdUSP, 2004.

RILEY, B. Colour for the painter. In LAMB, T.; BOURRIAU, J. (eds) Colour Art \&

SOGA, D., KOHATSU, D., MURAMATSU, M. Revisitando os prismas caseiros. Física na Escola, v.16, n 2, 2019. Disponível em http://www1.fisica.org.br/fne/phocadownload/Vol16-Num2/a14-low.pdf [acesso em 08.10.2019].

STROSBERG, E. Art and science. 2ed. New York: Abbeville, 2015. Edição Kindle. 
TEIXEIRA, J.N. Categorização do nível de letramento científico dos alunos do Ensino Médio. Dissertação de Mestrado. Instituto de Fsica, Faculdade de Educação, Universidade de São Paulo, 2007.

WEISSKOPF, V. How Light Interacts with Matter. Scientific American, September 1968, v.219, 3.

WERTSCH, J.V. Vygotsky and the Social Formation of Mind. Cambridge: Harvard University Press, 1985.

WILLIAMSON, S. CUMMINS, H. Light and Color in Nature and Art. New York: John Wiley and Sons, 1983.

VIGOTSKI, L. S. A construção do pensamento e da linguagem. Trad. P. Bezerra. $2^{\underline{a}}$ edição, São Paulo: WMF Martins Fontes, 2009. (3를 tiragem, 2018)

VIGOTSKI, L.S. Imaginação e criação na infância. Apresentação e comentários Ana Luiza SMOLKA; Trad. do russo: Zoia PRESTES. São Paulo, Ática, 2009.

VIGOTSKI, L. S. Pedagogia pedagógica. Trad. C. Schilling. Porto Alegre: Artmed, 2003.

VIGOTSKII, L. S, LURIA, A.R., LEONTIEV, A.N. Linguagem, desenvolvimento e aprendizagem. Trad. M.da P. Villalobos. 16ª ed. São Paulo: İcone, 2018.

VYGOTSKY, L.S. A formação social da mente. Org. M. Cole, V.John-Steiner, S. Scribner, E. Souberman. Trad. J.Cipolla Neto, L.S. Menna Barreto, S.C. Afeche. $2^{\mathrm{a}}$ ed. São Paulo, Martins Fontes, 1988.

VYGOTSKY, L.S.; LÚRIA, A.R. Estudos sobre a história do comportamento: símios, homem primitivo, e criança. Trad. Lólio Lourenço de Oliveira. Porto Alegre: Artes Médicas, 1996. 


\section{APÊNDICE 1}

\section{Orientação para produção do "livro de arte"}

Dos diversos instrumentos utilizados pelo homem, o mais espetacular é, sem dúvida, o livro. Os demais são extensões de seu corpo. O microscópio, o telescópio são extensões de sua vida; o telefone é extensão de sua voz; em seguida, temos o arado e a espada, extensões de seu braço. O livro, porém, é outra coisa: o livro é uma extensão da memória e da imaginação.

Jorge Luís Borges. O Livro. ${ }^{* 39}$

Como expressar o conhecimento científico através da Arte?

O objetivo do "livro de arte" é narrar seu percurso durante o curso utilizando a Arte como meio de comunicação. Algumas sugestões: você pode produzir uma obra e um texto explicativo, um infográfico, uma história em quadrinhos... Solte a imaginação!!!

Os temas abordados durante o curso foram:

Interação luz-matéria: reflexão, absorção e transmissão da luz.

Percepção de cores.

Branco e preto.

Cores espectrais.

Cores primárias - luz, impressão e pintura.

Mistura aditiva (de luz) e subtrativa (pigmentos).

${ }^{39}$ Disponível em https://outraspalavras.net/blog/o-livro-por-jorge-luis-borges/ [cesso em 15.01.2019]. 


\section{APÊNDICE 2}

\section{Avaliação pré e pós-curso (com gabarito)}

Questão 1: Marque Verdadeiro ou Falso.

O que nós sabemos sobre cores?

1. Ao iluminar um determinado objeto com luz branca, nós o enxergamos vermelho. Para que isto aconteça, ocorrem dois fenômenos ópticos simultâneos: reflexão e absorção. [IDENTIFICA FENÔMENOS ÓPTICOS]

2. A percepção cor de um objeto depende somente de suas características físicas e químicas. [RECONHECE QUE A PERCEPÇÃO DEPENDE DA CULTURA]

3. A diferença de iluminação ambiente modifica nossa percepção de cor dos objetos (uma maçã vermelha, por exemplo, pode ser vista com outra cor).

[RECONHECE QUE A COR DEPENDE DA LUZ INCIDENTE]

4. O vitral colorido é utilizado como elemento estético em muitas igrejas. Os fenômenos ópticos predominantes na interação da luz com o vidro são absorção e transmissão da luz. [IDENTIFICA FENÔMENOS ÓPTICOS E FUNCIONAMENTO DE FILTRO]

5. Luz vermelha com a luz verde misturadas na mesma quantidade resulta em luz amarela. [COMPREENDE MISTURA ADITIVA DE CORES]

6. Tinta vermelha misturada à tinta verde resulta na cor preta ou quase.

[COMPREENDE MISTURA SUBTRATIVA DE CORES][QUASE = COR ESCURA - MARROM, VERDE ESCURO, AZUL ESCURO]

7. Todas as cores na tela do smartphone e do computador são formadas a partir das cores vermelho, verde e azul. [COMPREENDE MISTURA ADITIVA DE CORES E APLICA NO COTIDIANO]

8. Um artista que possui tintas nas cores primárias mais a tinta branca e a preta consegue formar todas as cores de que precisa. [COMPREENDE MISTURA SUBTRATIVA DE CORES E APLICA NO COTIDIANO]

9. Dois carros, um branco e outro preto, de mesma marca e modelo permanecem estacionados durante o dia na rua a céu aberto. Ao final do dia, a temperatura no interior do carro preto estará maior que no carro branco porque a tinta preta absorve mais luz que a tinta branca.

[COMPREENDE QUE PRETO ABORVE MAIS QUE BRANCO E A ENERGIA ABSORVIDA SE TRANSFORMA EM CALOR]

10. $\mathrm{O}$ arco íris contém sete cores.

[O ESPECTRO TEM QUANTAS CORES O OBSERVADOR PERCEBE, NÃO NECESSARIAMENTE SETE.] 
Questão 2. Claude Monet, o representante mais genuíno do Impressionismo, gostava de pintar a mais pura percepção da interação da luz com os objetos e com a atmosfera. Sua investigação sobre isso resultou nas famosas séries de pintura de um mesmo local. Entre 1892 e 1893, Monet pintou a famosa série da catedral de Roeun , na França, ao longo do dia e do ano, em condições atmosféricas adversas e pontos de vista diversificados, resultando num conjunto de trinta em pintura a óleo. A seguir, apresentamos as imagens de uma mesma fachada. A numeração vem do catálogo Wildenstein. Observe-as atentamente.

\section{Catedral de Rouen. Ponto de vista no Louvet.}

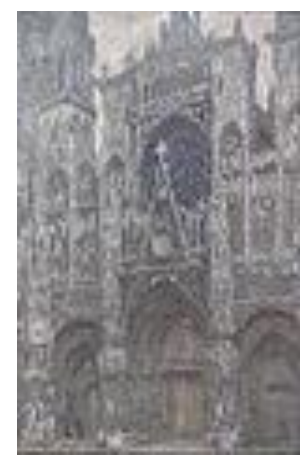

O portal do tempo cinzento - W1321, Musée d'Orsay.

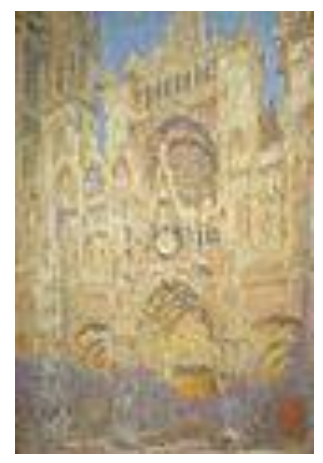

Catedral de Rouen W1326, Museu Pushkin, Moscou
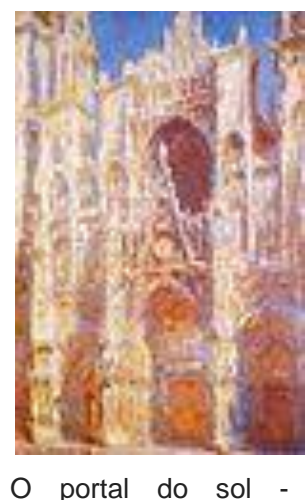
W1322, coleção particular.

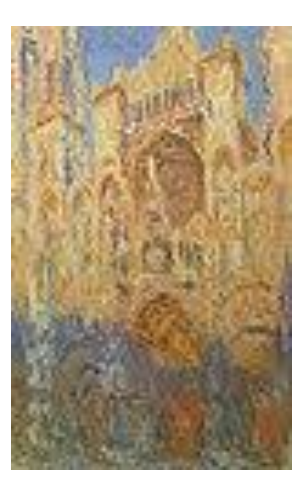

Efeito do sol, final da tarde - W1327, Museu Marmottan.

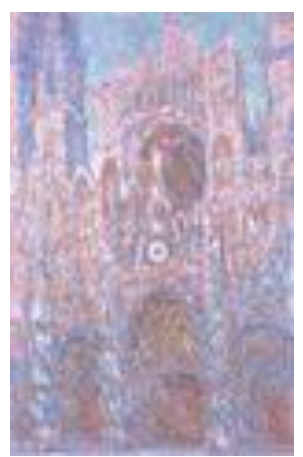

Sinfonia em cinza e rosa - W1323, Museu Nacional de Gales, Cardiff.

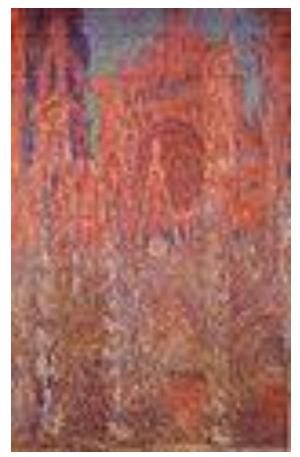

Catedral de Rouen, noite-W1328, Museu de Arte de Pola.

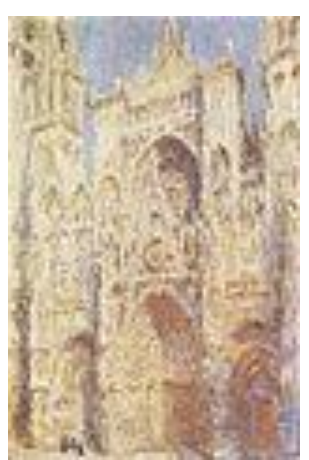

O portal, sol - W1324, galeria nacional da arte, Washington.

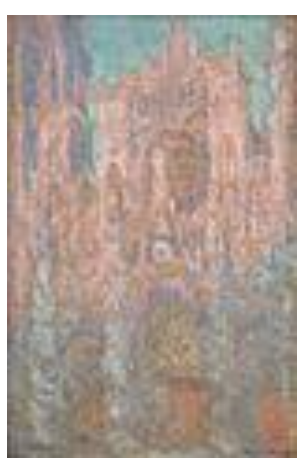

No final da tarde -

W1329, Museu Nacional da Sérvia.

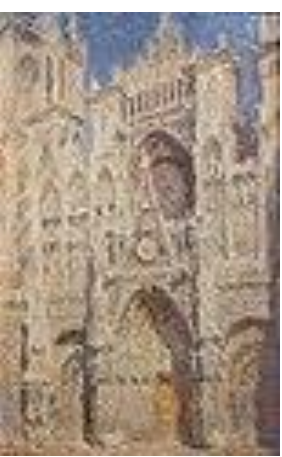

O portal, sol W1325,

Metropolitan Museum of Art.

https://commons.wikimedia.org/wiki/Monet - Les Cath\%C3\%A9drales de Rouen - Acesso em 25.10.2018

O que essas imagens podem dizer sobre luz e cor? Explique os conceitos científicos relativos aos fenômenos envolvidos.

\section{Resposta:}

Nível básico - A cor percebida pelo observador depende da luz refletida pelo objeto que depende da luz incidente. Há uma relação de interdependência entre cor percebida pelo observador, luz refletida e luz incidente.

Nível avançado - Nas situações exibidas acima, a luz incidente é a luz solar que foi modificada pelas condições atmosféricas e pelo horário. 


\begin{abstract}
ANEXO 1
Il Seminário de Professores da Escola Pública (SEPEP) - São Paulo, SP, Brasil - 16 a 19 de julho de 2018
\end{abstract}

Associação de Professores da Escola Pública (APEP) Instituto de Física, Universidade de São Paulo (IFUSP)

\title{
Oficina: Cor e ciência no ensino de arte
}

Carita Pelição' $(E M)$, Escola Estadual Prof ${ }^{a}$ Alva Fabri Miranda.

Dóris Kohatsu² (ES). Instituto Federal de São Paulo

carita.pe@outlook.com¹, doriskohatsu@usp.br².

Palavras-Chave: cor, ciência, arte.

Introdução

A disciplina arte é comumente associada a aulas de desenho ou aulas de cópia. Infelizmente, essa ideia vai além do espaço da sala de aula e estende-se aos gestores de ensino porque representa a realidade de muitas escolas. Para inovar o ensino de arte e desconstruir estereótipos, essa oficina mostrará que é possível associar conceitos da ciência de forma prática, divertida e com uso de materiais acessíveis.

Objetivos: desenvolver as concepções sobre cores nas aulas de arte utilizando conceitos e materiais científicos de fácil acesso; realizar atividades científicas e artísticas dentro da perspectiva do ensino investigativo; ampliar o repertório cultural dos alunos e professores; despertar o interesse do aluno; inovar a aula de arte.

Conteúdo: Cores primárias e secundárias; decomposição da luz branca; Disco de Newton; espectroscópio; cromatografia; círculo cromático; significado das cores; análise e interpretação do filme "Divertida Mente" através do significado das cores.

\section{Descricão}

Explicação sobre as cores primárias e secundárias, experimentando-as através de lápis de cor.

Construção de espectroscópio para a decomposição da luz branca e confecção do Disco de Newton.

Cromatografia (papel para filtro de café e canetinha) e observação das cores.

Estudaram sobre o círculo cromático. Significado das cores.

Como elaborar uma análise e interpretação sobre as cores dos personagens do filme "Divertida Mente" baseado no significado das cores.

\section{Referências Blbliográficas/Bibliografta}

BARBORA, Ana Mae. Inquietações e mudanças no ensino da arte. São Paulo: Cortez, 2012.

BRITO, N. B. de. REIS, J. C. As relações entre a Ciência e a Arte no século XIX e o conceito de cor in: III Conferencia Latinoamericana del International, History and Philosophy of Science Teaching Group IHPST - LA 2014. Santiago de Chile, 1719 de Noviembre. p. 21.

CARRANO, Eveline; REQUIÃO, Maria Helena. Materiais de arte: sua linguagem subjetiva para o trabalho terapêutico e pedagógico. Rio de Janeiro: Wak Editora, 2013.

FERRAZ, Maria Heloísa Corrêa de Toledo; FUSARI, Maria Felisminda de Rezende e. Arte na educação escolar. - 4. Ed. São Paulo: Cortez, 2010.

FERREIRA, Kacianni. Psicologia das cores. Rio de Janeiro: Wak Editora, 2013.

FONTE, Paty. Pedagogia de projetos: ano letivo sem mesmice. Rio de Janeiro: Wak Editora, 2014

MORTIMER, E. F.; SCOTT, P. Atividade discursiva nas salas de aula de Ciências. Investigações em Ensino de Ciências, Porto Alegre, v.7, número 3, p. 3, 2002.

PILLAR, Analice Dutra. A educação do olhar no ensino das artes. Porto Alegre: Mediação, 2011.

** Disponível em: https://docs.wixstatic.com/ugd/edec2e f076829f144e4cba9a03844b46db6d54.pdf [acesso em 26.07.2019]. 


\title{
Comunicação oral: Cor e ciência no ensino de arte
}

\author{
Carita Pelição (EM) Escola Estadual Profá Alva Fabri Miranda. \\ Dóris Kohatsu² (ES) Instituto Federal de São Paulo \\ carita.pe@outlook.com¹, doriskohatsu@usp.br².
}

Palavras-Chave: cor, ciência, arte.

\section{Introdução}

Durante o ano letivo de 2017 percebi que os alunos do ensino médio da escola onde leciono, apresentaram dificuldades quanto ao conceito de cores (cores primárias, secundárias; misturas de cores; aplicação etc.). Para melhor desenvolver 0 processo ensino/aprendizagem, pretendia elaborar um projeto que abordasse 0 assunto de forma inovadora. Com 0 fim do ano e as inscrições para o $15^{\circ}$ Encontro USP Escolas abertas, notei que havia um curso que poderia me auxiliar, que era "Cor e ciência - a física das cores através da pintura", ministrado pela Prof ${ }^{a}$ Dóris Kohatsu. Fiz minha inscrição e felizmente fui selecionada. Foi uma semana incrível de intenso aprendizado, cada aula possibilitava construir ainda mais minhas ideias. Com incentivo e apoio integral da professora, apliquei o projeto durante o primeiro bimestre de 2018 nas turmas do primeiro e segundo ano do ensino médio (15/16 anos em média), da Escola Estadual Profa ${ }^{-}$Alva Fabri Miranda, na cidade de Pederneiras/SP, no espaço da própria sala de aula, procurando trabalhar de forma individual e em grupo.

\section{Proposta}

Os objetivos foram: desenvolver as concepções sobre cores nas aulas de arte utilizando conceitos e materiais científicos de fácil acesso; realizar atividades científicas e artísticas dentro da perspectiva do ensino investigativo; ampliar o repertório cultural dos alunos; despertar o interesse do aluno; inovar a aula de arte.

Conteúdo: Cores primárias e secundárias; a óptica de Newton; decomposição da luz branca; Disco de Newton; espectroscópio; pintando com as cores espectrais; cromatografia; círculo cromático; significado das cores; análise e interpretação do filme "Divertida Mente" através do significado das cores.

\section{Relato da Aplicação em Sala de Aula}

Foram necessárias 16 aulas de 50 minutos cada. As duas primeiras aulas foram utilizadas para fazer um levantamento das principais dúvidas dos alunos quanto ao tema. Também foi explicado sobre como seriam as próximas aulas e quais materiais precisariam levar (CD, canetinha, lápis de cor, caderno de desenho, caixinhas do tipo creme dental etc.). Na terceira e quarta aulas, explicou-se sobre as cores primárias, secundárias e terciárias, experimentando-as, nesse primeiro momento, através do lápis de cor. Pediu-se uma pesquisa sobre Newton para a próxima aula.

Na quinta, sexta, sétima e oitava, desenvolveuse a óptica de Newton, a decomposição da luz branca e o Disco de Newton baseado na pesquisa que fizeram em casa. Aqui, o professor levou círculos de papéis previamente cortados e peão para girá-los. Na nona e décima, os alunos construíram seus próprios espectroscópios e ficaram à vontade para descobrir os espectros pela escola. Nas aulas seguintes, fizeram a cromatografia com papel para filtro de café, copo, água e canetinha. Depois, estudaram sobre - círculo cromático (breve associação à maquiagem). Significado das cores. Por último, assistiram ao filme "Divertida Mente" e elaboraram uma análise e interpretação sobre as cores dos personagens baseado no significado das cores.

\section{Considerações finais}

O projeto teve um excelente desenvolvimento com as duas turmas (primeiro e segundo anos do Ensino Médio). A princípio, os alunos ficaram surpresos com o formato da aula, mas logo demonstraram bastante interesse e curiosidade, se empenharam em experimentar e vivenciar as propostas. O ponto negativo foi referente aos materiais. Mesmo sendo de fácil acesso (caixa de creme dental, CD, canetinha etc.), os alunos têm estabelecido uma cultura em não levar à escola os materiais solicitados. Nesse sentido, era preciso estar preparada. Apesar do tema ter sido delimitado, o conhecimento aprendido está sendo usado também nas aulas do segundo bimestre, principalmente com os segundos anos, uma vez que o assunto é desenho e todo o contexto que o envolve, como: luz, brilho, reflexo, sombra, penumbra etc.

\section{Referências Bibliográficas/Bibliografia}

BARBORA, Ana Mae. Inquietações e mudanças no ensino da arte. São Paulo: Cortez, 2012.

BRITO, N. B. de. REIS, J. C. As relações entre a Ciência e a Arte no século XIX e o conceito de cor in: III Conferencia Latinoamericana del International, History and Philosophy of Science Teaching Group IHPST - LA 2014. Santiago de Chile, 17- 19 de Noviembre. p. 21.

CARRANO, Eveline; REQUIÃO, Maria Helena. Materiais de arte: sua linguagem subjetiva para o trabalho terapêutico e pedagógico. Rio de Janeiro: Wak Editora, 2013.

FERRAZ, Maria Heloísa Corrêa de Toledo; FUSARI, Maria Felisminda de Rezende e. Arte na educação escolar. - 4. Ed. - São Paulo: Cortez, 2010.

FERREIRA, Kacianni. Psicologia das cores. Rio de Janeiro: Wak Editora, 2013.

FONTE, Paty. Pedagogia de projetos: ano letivo sem mesmice. Rio de Janeiro: Wak Editora, 2014.

MORTIMER, E. F.; SCOTT, P. Atividade discursiva nas salas de aula de Ciências. Investigações em Ensino de Ciências, Porto Alegre, v.7, número 3, p. 3, 2002.

PILLAR, Analice Dutra. A educação do olhar no ensino das artes. Porto Alegre: Mediação, 2011.

* Disponível em: https://docs.wixstatic.com/ugd/edec2e 8785862b12c84d4dafc47 a13f94e5c10.pdf [acesso em 26.07.2019] 